UNIVERSIDADE DE SÃO PAULO

INSTITUTO dE FíSICA / FACULDADE DE EdUCAÇÃO

\title{
UTILIZAÇÃO E COMPREENSÃO DO COMPUTADOR: \\ UM OLHAR NO DIA-A-DIA DO PROFESSOR
}

DISSERTAÇÃO DE MESTRADO

MARCOS ROGÉRIO TOFOLI

YASSUKO HOSOUME (ORIENTADORA)

Este exemplar corresponde à redação final da dissertação defendida por Marcos Rogério Tofoli e aprovada pela Comissão Examinadora.

Data: 19/09/2003

Assinatura:

Comissão Examinadora:

Profa. DRa. YASSUKo HoSOUME - IF/USP

Profa. DRa. MARIA José Bechara - IF/USP

Prof. Dr. Dirceu da Silva - FE/UNICAMP

\section{SÃO PAULO}

2003 



\author{
UNIVERSIDADE DE SÃO PAULO \\ INSTITUTO DE FÍSICA / FACULDADE DE EDUCAÇÃO \\ DISSERTAÇÃO DE MESTRADO
}

\title{
UTILIZAÇÃO E COMPREENSÃO DO COMPUTADOR:
}

UM OLHAR NO DIA-A-DIA DO PROFESSOR

Marcos Rogério Tofoli

Orientadora: Profa. Dra. Yassuko Hosoume

Este exemplar corresponde à redação final da dissertação defendida por Marcos Rogério Tofoli e aprovada pela Comissão Examinadora.

Data:

Assinatura:

Comissão Examinadora:

Profa. DRa. YASSUKo Hosoume - IF/USP

Profa. Drá. MARIA José Bechara - IF/USP

Prof. Dr. DiRCeu da SILVA - FE/UNICAMP 
(C) by Marcos Rogério Tofoli, 2003.

FICHA CATALOGRÁFICA

Preparada pelo Serviço de Biblioteca e Informação do Instituto de Física da Universidade de São paulo Bibliotecário: - CRB-

Tofoli, Marcos Rogério.

Utilização e compreensão do computador: um olhar no dia-a-dia do professor / Marcos Rogério Tofoli. - São Paulo, SP: [s.n.], 2003.

Orientador : Yassuko Housome.

Dissertação (mestrado) - Universidade de São Paulo, Instituto de Física / Faculdade de Educação - Departamento de Física Experimental.

Unitermos: 1. Física - Estudo e ensino.

2. Utilização, compreensão.

3. Informática.

4. Professores.

5. Computador. I. Hosoume, Yassuko II.

Universidade de São Paulo. Faculdade de Educação. III. Título. 
Prosseguimos. Reinauguramos.

Abrimos olhos gulosos a um sol

Diferente que nos acorda

Para os descobrimentos.

Esta é a magia do tempo.

(Carlos Drummond de Andrade)

Em memória de Joana Catini Ferraresso, um grande símbolo e ídolo da minha vida. 


\section{AGRADECIMENTOS}

Já há muitos anos venho intensamente tentando desenvolver reflexões em torno das relações entre a Informática e o ensino da Física. Quando encontrei a professora Yassuko Hosoume (nos corredores da pós), em meados de 1998, por intermédio de Alexandre Custódio e José Alves, então aluno da pós-graduação e já professor de Física no nível médio, procurava uma perspectiva de reflexão sobre o ensino que se aproximasse de minhas ideologias. Encontrei muito mais. Descobri que podia aliar aquelas ingênuas e fecundas idéias, que ainda hoje continuam a amadurecer, ao ensino da Física de forma efetiva. De professora a orientadora de mestrado, somaram-se anos de uma interlocução, ora tímida, porém, sempre muito produtiva, que é parte fundamental deste trabalho. Interlocução que produziu, deslocou, reafirmou, modificou sentidos, mas principalmente valores. Interlocução que só pôde ser estabelecida por uma perspectiva de formação que tem proporcionado inúmeras oportunidades aos seus orientandos de participar ativamente das atividades desenvolvidas pelo grupo. Interlocução que se deu também no espaço da amizade. Este trabalho resulta do esforço para constituir a concepção de ensino a partir, principalmente, das reflexões e idéias que circularam no nosso grupo de pesquisa e, ao mesmo tempo, do esforço no sentido de contribuir para a perspectiva da reflexão deste grupo. Se consegui o segundo intento, não sei. Mas estou bastante satisfeito com o primeiro. A Yá, agradeço, de coração, pela orientação, pela dedicação em criar as melhores condições possíveis de trabalho para nós, orientandos, pela esperança e confiança que deposita em nosso trabalho, pela amizade, enfim, meu agradecimento não tem palavras.

Aos membros do grupo de pesquisa, todos, de um modo ou de outro, também partes desta interlocução: Andréia, Cristina, Eraldo, Graziela, Marcelo, Nádia e Wolney agradeço pelas contribuições e apoio dados ao trabalho. Para Ivanilda e Rebeca que em especial, agradeço por terem me auxiliado de maneira ímpar na redação deste trabalho, principalmente na rearticulação das idéias do texto final. Às professoras Maria Regina 
Kamawura e Maria José Bechara pela leitura atenta do projeto de qualificação e pelas valiosas críticas e sugestões.

Agradeço especialmente aos professores João Martins e Jairo Alves Pereira, que possibilitaram o enriquecimento da pesquisa com os questionários aplicados em seus cursos de formação continuada para professores em São Paulo e no Acre. Agradeço, inclusive, a todos os professores que se propuseram a responder a estes questionários.

A todos os colegas do corredor pelo incentivo, questionamento e respeito às minhas idéias e por todos os momentos felizes que compartilhamos. À Moniquinha, pela pessoa que é, e por sempre apoiar-me nos momentos difíceis da redação desse trabalho.

Aos meus Professores e Colegas do IFUSP, FEUSP e IQUSP, pela minha formação e por me proporcionarem, de uma maneira muito agradável e importante, à iniciação no mundo da pesquisa de ensino de Ciência, em especial carinho para o Menezes, com o qual aprendi muito o que é ser um educador.

A todos que foram meus alunos.

A todos os colegas de trabalho que sempre torceram pelo sucesso desta pesquisa. Em especial para Isabel e Luciana pela releitura atenta do trabalho, e para Silvia na correção do abstract.

Aos funcionários da Faculdade da USP, principalmente ao Aílton, pelo auxílio em todos os problemas administrativos.

Ainda não posso deixar de expressar minha gratidão, carinho e reconhecimento à Guacira, pelos diálogos, leituras, incentivo e pela paciência. E aos meus pais Valdemar e Leonice, aos meus irmãos Lucilene e Júlio, simplesmente por tudo e por me compreenderem nesse período complicado do mestrado. 



\section{RESUMO}

TOFOLI, M. R. Utilização e compreensão do computador: Um olhar no dia-a-dia do professor. 2003. 139 f. Dissertação (Mestrado) apresentada ao Instituto de Física e à Faculdade de Educação da Universidade de São Paulo, São Paulo, 2003.

A presença dos microcomputadores no ensino, os objetivos e as propostas para o seu uso têm sido objeto de diversas discussões e encaminhamentos, nos mais diferentes níveis de intervenções como o Ministério de Educação e Cultura (MEC) através de convênios com as Secretarias Estaduais e Municipais de Educação, e também, nas instituições formadoras de professores como as universidades e centros de pesquisas.

Uma breve análise, sobre trabalhos publicados nos últimos dez anos pela comunidade da área de Ensino de Física (Simpósios Nacionais de Ensino de Física, Revista Brasileira de Ensino de Física e Caderno Catarinense de Ensino de Física), identifica as diferentes contribuições que a tecnologia da informação aplicada à Educação pode proporcionar ao ensino da física, e aponta a existência de uma grande preocupação em produção e utilização de softwares/simuladores. Percebe-se a raridade em trabalhos relacionados diretamente com o professor diante a utilização do computador.

O conhecimento das relações que os professores estabelecem com esse equipamento, seria o ponto de partida para o desenvolvimento de estratégias para sua utilização na educação. Assim, esse trabalho procura investigar as idéias dos professores de Física com relação à presença e ao uso de microcomputadores em seu cotidiano, incluindo seu cotidiano escolar. A pesquisa foi feita, por meio de questionários, com professores do ensino médio da rede pública.

Os resultados indicam que os professores reconhecem o espaço dos microcomputadores no ensino, mas, mesmo reconhecendo sua importância e potencialidade, como a de facilitar e agilizar trabalho de preparação das aulas, de motivar as aulas ou de possibilitar realização de simulações experimentais, ainda não utilizam efetivamente esse instrumento em suas atividades pedagógicas. Também deixam de compreender que a partir do computador novas formas de transformar a prática pedagógica devem ser concebidas, o que indica a necessidade de uma atenção maior às possíveis relações que se deseja promover no processo educacional.

Palavras-chave: computador, formação de professores de física, utilização e compreensão. 



\begin{abstract}
TOFOLI, M. R. Computer use and understanding: A look at the day-to-day teacher. 2003. 139 f. Thesis (Mestrado) presented to "Instituto de Física" and to "Faculdade de Educação da Universidade de São Paulo", São Paulo, 2003.
\end{abstract}

The presence of microcomputers in teaching, the goals and the proposals for its use have been the object of several discussions and referring, in the most different levels of intervention as the Ministry of Education and Culture (MEC) through partnerships with State and Municipal Secretary Office of Education, and also with institutions that prepare teachers such as universities and research centers.

An analysis about published work in the last ten years by the community of Physics Teaching Area (National Presentations of Teaching Physics Teaching, Revista Brasileira de Ensino de Física and Caderno Catarinense de Ensino de Física), identified different contributions that information technology applied to Education may have to Physics Teaching, pointing the existence of a great awareness with the production and use of softwares simulators. However, rare are the works that investigate the relationship established by teachers with the computer.

Knowing the different postures of the teacher toward this equipment, would be starting point to the development of strategies for its use in education. Therefore, this work looks for investigating how Physics teachers take and understand the presence and the use of microcomputers in their daily routine, including their school daily lives. The research was made, through questionnaires, with teachers of secondary schools of the public teaching board.

The results show that the teachers know the space of microcomputers in teaching, but, even knowing its importance and power, as, for example, facilitating and speeding up the preparation of classes or making experimental simulations, yet they don't use effectively this instrument in their pedagogical activities. Even more, they still don't comprehend that the use of the computer in the classroom demands the conceptions of new pedagogical practices, which show the necessity of a greater attention in projects using computers preparing and graduating teachers.

Keywords: computer, physics teacher's education, use and understand. 
1. O COMPUTADOR NA EDUCAÇÃO........................................... 14

1.1 UMA NOVA LINGUAGEM........................................................ 15

1.2 UM NOVO INSTRUMENTO NA ESCOLA....................................... 17

1.3 OS SOFTWARES EDUCATIVOS............................................... 19

1.4 O PROFESSOR DIANTE DO COMPUTADOR................................. 23

1.5 A FORMAÇÃO DE PROFESSORES EM INFORMÁTICA........................ 25

2. UM PANORAMA DO ENSINO DE FÍSICA E A INFORMÁTICA...... 30

2.1 O ENSINO DE FÍ́IICA E A INFORMÁTICA NO SNEF........................... 30

2.1.1 X Simpósio Nacional de Ensino de Física 32

2.1.2 XI Simpósio Nacional de Ensino de Física 33

2.1.3 XII Simpósio Nacional de Ensino de Física 34

2.1.4 XIII Simpósio Nacional de Ensino de Física 35

2.1.5 XIIV Simpósio Nacional de Ensino de Física 36

2.1.6 XV Simpósio Nacional de Ensino de Física 37

2.2 O ENSINO DE FÍSICA E A INFORMÁTICA NA RBEF E NO CCEF......... 38

2.3 UM QUADRO COMPARATIVO................................................ 40

\section{UTILIZAÇÃO E COMPREENSÃO DO COMPUTADOR:}

UM OLHAR DO PROFESSOR DE FÍSICA....................................... 45

3.1 ETAPA I - O PROFESSOR NO ESPAÇO DA INFORMÁTICA.................. 46

I.1 Espaço da Informática 50

l.1.1 Sobre o computador 51

l.1.2 Sobre a Internet 52

I.2 O computador na escola $\quad 54$

3.2 ETAPA II -A INFORMÁTICA NO ESPAÇO DO PROFESSOR.................. 55

II.1 Espaço da Informática $\quad 59$

II.1.1 Grupo de questão -1

II.1.2 Grupo de questão -2

II.1.2.1 Sobre o computador 64

II.1.2.2 Sobre a Internet 67

II.1.2.3 Sobre a visão do professor diante das novas tecnologias 69

II.2 Informática na educação 72

II.2.1 Laboratório de informática na escola 78

Il.1.2.2 Sobre a Internet $\quad 67$

3.3 RESULTADOS E CONSIDERAÇÕES............................................... 79

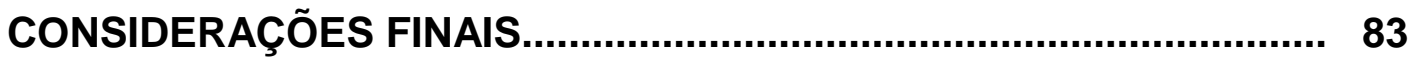

REFERÊNCIAS BIBLIOGRÁFICAS................................................ 89

ANEXOS 


\section{INTRODUÇÃO}

Hoje há uma consciência de que a apresentação da Ciência como fato concebido, fragmentado ou descontextualizado não tem contribuído para a formação de alunos capazes de compreender e atuar nesse mundo contemporâneo, onde as transformações ocorrem com tal rapidez que, freqüentemente, somos surpreendidos com novos conhecimentos, sejam de ordem científica ou tecnológica. Há a necessidade de se trabalhar o processo educativo, em ciências naturais, de forma articulada por saberes comuns à Biologia, Física e Química, isso porque o saber científico como um todo, é revelado por olhares particulares de diferentes áreas de conhecimento, que desvelam propriedades específicas, com procedimentos diferenciados. Também é imprescindível que os conteúdos contemplem aspectos tecnológicos e práticos, integrando o aprendiz ao mundo contemporâneo.

O ensino de física deve contribuir para a compreensão do mundo real, concebendo os conceitos e as quantificações das grandezas como formas investigativas dos fenômenos inseridas em situações significativas e contextualizadas. Nessa sentido, os $\mathrm{PCNs}^{1}$ apontam como possibilidades de estudo, por exemplo, a Óptica e o Eletromagnetismo, que encaminham uma leitura do mundo da informação e comunicação; a Termodinâmica e a Eletricidade que servem como instrumentos de compreensão e proposição de questões envolvendo meio ambiente e fontes de energia; o estudo da natureza ondulatória e quântica da luz e sua interação com os meios materiais, como, por exemplo, o estudo de componentes eletrônicos contemporâneos e os semicondutores. Assim, a compreensão da Ciência contemporânea poderia envolver seus aspectos tecnológicos, sociais e as implicações do dia-a-dia, fazendo com que o estudo de Física possibilite um novo aprender, com uma nova postura pedagógica.

\footnotetext{
${ }^{1}$ Parâmetros Curriculares Nacionais, Secretaria de Educação e Cultura.
} 
Dessa maneira, trabalhar o ensino de Física, num novo contexto, requer mudanças. Entre elas, pode-se citar a necessidade de professores mais bem qualificados, com nova visão de educação; propostas curriculares que valorizem a construção de conhecimento e não apenas aprovações em vestibulares; escolas mais equipadas com recursos didáticos como laboratório, biblioteca, televisão, computador etc..

Parece que, com a utilização do computador, a mudança poderia ser facilitada, já que esse recurso veio contribuir para o ensino de Física, incrementando o processo interativo de aprendizagem, originando uma nova cultura. Porém, não uma cultura de consumo, como muitos a têm e detêm, e sim uma cultura de/em produção. Cultura essa que Lévy chama de cibercultura $^{2}$ e que, a cada dia, o acesso à Internet evidencia com o aumento do número de informações, publicações e artigos, enfim, com uma literatura que está contribuindo para que os sujeitos possam navegar e se alimentar dessa cultura existente no "ciberespaço". Alguns trabalhos já proporcionam algumas inovações, possibilitando a criação e exploração de experiências de educação on-line, um exemplo é o projeto de Educação Continuada de Professores (PEC - Construindo Sempre) do Governo do Estado de São Paulo.

Para Valente (1993:40), a educação através do computador faz com que professor e aluno assumam uma nova postura, pois trata-se de uma mudança paradigmática na educação, "um novo paradigma que promova a aprendizagem ao invés do ensino, que coloca o controle do processo de aprendizagem nas mãos do aprendiz, e que auxilia o professor a entender que a educação não é somente a transferência de conhecimento, mas um processo de construção do conhecimento pelo aluno, como produto de seu próprio engajamento intelectual ou do aluno como um todo".

\footnotetext{
${ }^{2}$ Cibercultura - Conforme Lévy, cibercultura, "especifica aqui o conjunto de técnicas (materiais e intelectuais), de práticas, de atitudes, de modos de pensamento e de valores que se desenvolvem juntamente com o crescimento do ciberespaço". (LÉVY, 1999:17).

${ }^{3}$ Segundo Lévy, Ciberespaço "é o novo meio de comunicação que surge da interconexão mundial dos computadores. O termo especifica não apenas a infra-estrutura material da comunicação digital, mas também o universo oceânico de informações que ele abriga, assim como os seres humanos que navegam e alimentam esse universo" (LÉVY, 1999:17).
} 
Diante disso, cabe indagar como as pesquisas em ensino de Física, em particular aquelas relativas ao uso do computador, abordam essas questões. Será que estas produções realmente têm apontado para mudanças de cultura, de paradigmas, ou contribuído nesta nova forma de sociabilidade em que se insere?

A preocupação excessiva com a aquisição de equipamentos e a proliferação de programas de computadores para educação (software educativo) parecem, num olhar ingênuo, ser o caminho para inserir a Informática na Educação e também no ensino de Física. Mas esses aspectos, por si só, não garantem uma utilização eficaz do computador nos diferentes níveis e modalidades de ensino. A formação dos professores, essencial para o uso efetivo dos recursos da informática, não tem sido observada como prioridade educacional, diferentemente da aquisição de equipamentos e aplicativos, deixando, muitas vezes, transparecer a idéia equivocada de que o computador e o software resolverão os problemas educativos.

Para confirmar isso, basta lançar um olhar sobre a forma como vem ocorrendo a inserção de computadores nas escolas (estaduais ou particulares). A preparação propiciada aos professores acaba freqüentemente ocorrendo através de rápidos treinamentos, em geral, em torno de algumas novidades que essa tecnologia às vezes proporciona. Em alguns casos, a instituição contrata instrutores para ministrar aulas de Informática aos alunos, sem ter a preocupação com a integração do computador ao processo pedagógico e deixando para segundo plano a formação docente.

Percebe-se, assim, que a formação não pode ser dissociada da atuação, nem se limitar à dimensão pedagógica ou a uma reunião de teorias e de técnicas. Segundo Valente (1993) "a formação e a atuação de professores para o uso da Informática em Educação é um processo que acaba inter-relacionando o domínio os recursos tecnológicos com a ação pedagógica e com os conhecimentos teóricos necessários para refletir, compreender e transformar essa ação". 
Contudo, há ainda pouco conhecimento sobre o ponto de vista dos professores em relação a essas questões, sobre sua opinião em relação aos computadores ou de como interagem com eles. Para qualquer transformação que se almeja na compreensão e inserção da informática no ensino de Física, o primeiro passo é verificar, então, a relação que os professores estabelecem com esse novo instrumental - o computador.

Para esclarecer tais questões, procura-se, no primeiro capítulo desse trabalho, compreender como a Educação e a Informática, dois importantes temas de pesquisa, podem contribuir para a ação pedagógica, destacando de forma geral suas possibilidades, limitações e implicações. Busca-se também entender a origem das relações entre Educação e Informática no Brasil, bem como verificar alguns projetos propostos para 0 seu desenvolvimento.

No segundo capítulo, busca-se compreender como o computador tem sido abordado em pesquisas no ensino de Física em nosso país, analisando em especial aqueles relativos à formação do professor. Foram analisadas as produções intelectuais apresentadas nos principais eventos e publicações da área nos últimos dez anos, com especial atenção ao Simpósio Nacional de Ensino de Física (SNEF), entre 1993 e 2003 (edições X, XI, XII, XIII, XIV e XV), à Revista Brasileira de Ensino de Física (RBEF 1993 a 2002) e ao Caderno Brasileiro de Ensino de Física (CBEF - 1993 a 2002).

No terceiro capítulo procurou-se investigar que idéias os professores de Física têm acerca do uso do computador em geral e, em particular, da Internet na escola. $\mathrm{O}$ desenvolvimento dessa pesquisa foi realizado em duas etapas; na primeira, procurou-se verificar a familiaridade do professor no espaço da informática através da identificação de seu conhecimento sobre alguns de seus elementos, como, por exemplo, a freqüência de acesso às páginas na Internet, o uso do correio eletrônico ou a participação numa lista de discussão. Na segunda etapa, que complementa a primeira, a pesquisa foi direcionada para a área mais específica da educação, procurando identificar a visão do professor sobre o computador na escola, seja em 
relação aos objetivos de seu uso, seja em relação às possibilidades e formas de sua inserção na prática pedagógica.

Retomando e encerrando as análises desenvolvidas ao longo desse trabalho, empreendemos, na última parte, as discussões finais, delineando, em termos gerais os principais resultados obtidos e ressaltando algumas questões pertinentes à produção de um novo conhecimento através do computador, dando especial atenção à formação de professores. 


\section{O COMPUTADOR NA EDUCAÇÃO}

A partir da chamada Primeira Revolução Industrial, as máquinas passaram a pertencer ao universo sócio-econômico do ser humano. Embora no início ainda fosse uma relação homem-máquina distanciada, uma nova concepção do processo de produção emergiu, com caráter cada vez mais científico e técnico. Com o final da Segunda Guerra Mundial, as máquinas invadiram o universo vivencial imediato, prestando-se a realizar pequenas tarefas domésticas. A relação homem-máquina torna-se, assim, direta e mais intensa, dos eletrodomésticos às ferramentas.

A Segunda Revolução Industrial, a da Informática, apresentou o computador à sociedade. $\mathrm{E}$ a inserção desta máquina, que processa e armazena informações, também ocorreu inicialmente de forma mais distanciada, em ambientes distintos, como o universitário, o bélico e 0 bancário. Hoje, no entanto, mesmo quem não possui um $P C$ (personal computer), compra produtos com preço e identificação cifrados em código de barras, ou paga seus débitos com a mesma leitura óptica; realiza exames médicos como a tomografia computadorizada, por exemplo; ouve o som mais nítido e assiste a imagens de altas resoluções com a tecnologia DVD. $O$ aumento crescente da capacidade de processamento e armazenamento de informações indica que a presença do computador nas sociedades futuras será cada vez maior.

Com o advento da Internet pode-se falar de uma nova revolução, uma revolução na comunicação - informações são obtidas ou transmitidas a uma velocidade há pouco tempo não concebida, mas compatível com o ritmo atual da sociedade, hoje, sem dúvida, uma sociedade da informação.

Surge, assim, um novo desafio aos indivíduos dessas sociedades: não se colocarem apenas como consumidores deste sofisticado objeto tecnológico, mas de se posicionarem criticamente diante de sua utilização, como sujeitos que realizam a ação. E isto se reveste da maior importância, pois a tecnologia da informática é considerada um poderoso instrumento 
tecnológico, com alto poder de transformação, produção e dominação, traduzido numa nova concepção do próprio conhecimento. Daí a necessária e inevitável entrada do computador na Educação, meio privilegiado para evitar a cyber-exclusão.

Segundo Robinson Tenório (2001) "é na escola, para a maioria, que se dá à única chance de aquisição do conhecimento acumulado, da ciência e da tecnologia". Na esfera educacional, o computador hoje se faz necessário não somente em sua administração, mas também como mais um possível elemento tecnológico auxiliar do processo de ensinoaprendizagem, um recurso instrucional que ganha campo e vem sendo utilizado da pré-escola ao ensino superior.

Educação e Informática constituem, assim, importantes temas de pesquisa, podendo contribuir para a ação pedagógica, desde que se conheçam as possibilidades, limites e implicações de seu uso.

\subsection{Uma nova linguagem}

Do ábaco às calculadoras (máquinas de contar), que processam informações, o computador dá um grande salto quantitativo - pelo volume de informações processado e armazenado - e também qualitativo permitindo processar e armazenar dados de diferentes naturezas. Numa análise ingênua ou radical, para muitos a presença do computador acabaria por não desenvolver a linguagem escrita e a leitura, ambas já tão comprometidas neste universo áudio-visual. Para outros, dispensaria a aprendizagem dos cálculos básicos, o que os anos de convivência com as calculadoras já nos provaram não ser verdade, pois a calculadora apenas obedece a comandos. No entanto, principalmente com o correio eletrônico (email) e os chats, verifica-se uma crescente necessidade de saber se expressar por meio dessa nova linguagem, que tem suas próprias características, como a rapidez e a utilização de ícones. O fato é que o mundo hoje tornou-se, muito, imagens e sons. O computador, sem dúvida, envolve uma nova linguagem - nova, porém cada vez mais familiar.

O grande salto para a difusão do computador, em proporções nunca antes vistas ou imaginadas, ocorreu há menos de duas décadas com a nova 
interface gráfica. Se antes, para utilizar o computador, era necessário conhecimento de lógica e de alguns comandos em língua inglesa, hoje os programas são facilmente visualizados e executados, proporcionando e acelerando o desenvolvimento de várias ferramentas, dentre as quais podemos destacar os editores de texto, planilhas eletrônicas, bancos de dados, digitalizadores de imagem, programas de desenho e, mais recentemente, animações como efeitos especiais e desenhos animados, entre outros. Além disso, "através da Internet, é possível interligar um microcomputador (host) com outro, mesmo que eles possuam sistemas operacionais diferentes e estejam em pontos distantes do planeta. Por intermédio da Internet, é possível participar de grupos de discussão, trocar mensagens e também fazer compras sem sair do lugar. Foram então sendo desenvolvidos programas e equipamentos que tornaram o uso da Internet cada vez mais simples e barato" (Pretto, 1996).

Apesar disso, o computador ainda não é um objeto tecnológico democrático, pois os preços praticados pelo mercado ainda são inacessíveis para a maioria da população, assim como os softwares necessários para seu funcionamento. Como conseqüência direta, a Internet também ainda não é democrática, apesar dos esforços de promovê-la em diferentes locais e ambientes, públicos ou não.

Não é simplesmente em termos de linguagem que parece ocorrer uma transformação - é uma transformação também cultural, pois envolve novos procedimentos de busca e armazenamento de informações, modificando-se as relações entre aqueles que estão inseridos nessa nova dinâmica. Buscar essa nova relação passa por reconhecer um novo processo de contribuição de conhecimento e de ensino-aprendizagem. Um processo onde o conhecimento passa a ser entendido como uma rede e, como tal, "não apresenta um único centro, não é linear, possibilitando uma maior compreensão e proximidade entre concepções" (Machado,1999).

O computador, sendo um meio multiforme e com capacidades técnicas em evolução contínua, pode ser usado na escola de modo satisfatório. Diante da preocupação dos professores, que se encontram desarmados por não possuírem domínio em informática, o momento passa 
a ser propício para o início de um processo de construção de novos saberes pedagógicos, que associem o conteúdo disciplinar - e mesmo interdisciplinar - a esse instrumento tecnológico.

\subsection{Um novo instrumento na escola}

Já há algumas décadas se discute Informática na Educação. O hardware (máquinas e periféricos) e o software (programas) formam 0 sistema computacional. O aperfeiçoamento do hardware e seu barateamento, assim como dos softwares, principalmente os softwares com código fonte aberto (freeware), tornaram os recursos da informática um pouco mais acessíveis, possibilitando que um número maior de escolas, de professores e alunos adquiram tal equipamento. No entanto, esse custo ainda é alto, não sendo acessível à maioria das pessoas. Mesmo assim, o interesse pela Informática é cada vez maior.

O microcomputador é uma ferramenta muito importante para a escola como um todo, e segundo dados mais recentes do Instituto Nacional de Estatística e Pesquisa Educacional (INEP ${ }^{4}$ - 2003), do total de 20.220 estabelecimentos responsáveis pelo ensino médio, 50,5\% (10.168) escolas já foram atendidas e informatizadas, e 43\% (8.806) escolas possuem acesso à Internet. Ao todo, são 448.569 funções docentes para atender a 8.398.008 alunos matriculados. Assim, o número de escolas com infraestrutura ainda não parece ser suficiente para atender a toda demanda de alunos matriculados. Isso, mesmo considerando que todo o sistema de informática esteja disponível como um recurso didático para os professores, e não somente na administração.

Entre os vários objetivos e expectativas que encorajam o uso de computadores nas escolas (Lima, 1998), considera-se como mais relevantes "proporcionar meios para que o aluno enfrente a sociedade tecnológica, presente e futura, e auxiliar o processo de construção do conhecimento". O microcomputador, enquanto instrumento de ensino deve, portanto, promover o aprendizado de conteúdos ou estratégias para fazê-lo, possibilitando que

\footnotetext{
${ }^{4}$ Consulta feita no site www.inep.gov.br/estatisticas/perfil/resp uf reg.asp $(17 / 08 / 2003)$
} 
os alunos adquiram na escola, além da bagagem cultural, subsídios para obter conhecimentos fora dela.

Há diferentes usos do microcomputador enquanto instrumento de ensino como, por exemplo, os programas tutoriais, que guiam o usuário por caminhos que o levam a adquirir algum conceito ou habilidade; jogos educativos, nos quais é evidenciado o certo e o errado pela maneira como as peças do jogo se comportam; e simulações interessantes para o ensino de Física, como um laboratório virtual, envolvendo a criação de modelos dinâmicos e simplificados do mundo real.

O mandato e papéis principais da Educação são preparar (formar) adultos e crianças para viver na sociedade. Numa sociedade da informação, onde os computadores têm papel importante nas diversas atividades e áreas, acadêmicas e/ou profissionalizantes, seu uso se faz necessário numa variedade de atividades tais como desenho, escrita, busca e análise de informações, uso de processadores de texto, simulações, programas gráficos, banco de dados, planilhas eletrônicas, telecomunicações etc.. Pesquisas acadêmicas (Moraes,1993) evidenciaram que "quanto mais cedo uma criança for introduzida no mundo da computação, mais natural será seu comportamento diante deste novo contexto e, portanto, menos temores e preconceitos ela desenvolverá. Além disso, terá oportunidade de desenvolver uma maior preparação mental, técnica e afetiva para enfrentar a tecnologia ao seu redor".

Portanto, não basta às escolas terem computadores, os alunos precisam ter acesso a eles, conhecê-los e manipulá-los. Os professores precisam conhecer os computadores e softwares, utilizá-los e, mais que isso, reconhecê-los como mais um instrumento capaz de auxiliá-los em sua prática docente.

\subsection{Os softwares educativos}

Segundo Chant e Atkinson (1978), a investigação e o pensamento crítico podem ser despertados e alimentados por quatro métodos de aprendizagem: "a curiosidade - que leva o aluno a adquirir iniciativa própria 
e explorar, com relativa liberdade, qualquer tópico curricular; a articulação que resulta do processo exploratório decorrente da curiosidade, induzindo o aluno a direcionar sua investigação para um conteúdo curricular mais específico; a avaliação - que desenvolve a observação e compreensão direta deste conteúdo específico, conduzindo o aluno a uma forma de conhecimento; a reflexão - que proporciona a aplicação deste conhecimento para a resolução do problema surgido, inicialmente, pelo simples despertar da curiosidade. Cada um destes quatro métodos de aprendizagem busca desenvolver desejadas posturas no aluno que favoreçam, mais do que a construção do seu conhecimento, a busca por essa compreensão aprender a aprender.

Construcionismo é um conceito educacional definido por Seymour Papert (1985) segundo o qual a aprendizagem deveria estabelecer o ciclo denominado descrição - execução - reflexão - depuração, originalmente empregado na programação de computadores e, em Educação, no uso da metodologia e "linguagem Logo", também criada por Papert. Numa abordagem construcionista, utilizando-se do computador, o indivíduo visualiza suas construções mentais, estabelecendo uma relação dialética entre o concreto e o abstrato por meio de um processo interativo, o que favorece o processo de construção do conhecimento. Essa abordagem tem como um de seus princípios a criação de ambientes de aprendizagem ativa, que permitam ao indivíduo o emprego da heurística, para o teste de suas próprias idéias, teorias e hipóteses. O erro torna-se um objeto de análise, para que os equívocos cometidos sejam identificados e reformulados em um processo de reflexão e depuração que promova a aprendizagem e 0 desenvolvimento. O ciclo construcionista, embora aconselhado para aprendizagem promovida com o auxílio do computador, não se contrapõe aos quatro métodos de aprendizagem propostos por Chant e Atkinson, ao contrário, corrobora a idéia do computador como mais um instrumento pedagógico.

Os softwares, programas de computação, são também responsáveis pela funcionalidade e utilização eficiente da máquina. Quando se investiga uma estratégia para a introdução dos computadores nas escolas, além de 
ser necessária uma discussão sobre seu papel, sua linguagem e mesmo sobre essa nova concepção de conhecimento em rede, há a necessidade de se associar a discussão sobre o computador ao conceito do chamado software educacional. Neste caso, primeiramente, surge a problemática quanto à definição do que é um software educacional.

Segundo Chavez (1987), "Uma linguagem de programação pode ser um software educacional? Dificilmente Cobol seria assim considerada. Mas - LOGO...quem sabe? Um jogo pode ser considerado um software educacional? E se o jogo for pedagógico? Mas quando é que um jogo deixa de ser jogo e passa a ser pedagógico?... O software educacional deve ser conceituado em referência à sua função e não à sua natureza."

Para Campos e Rocha (1990), o professor pode contar, hoje, com vários tipos de softwares para apoiar alguma atividade curricular: "exercício e prática", "simulação", "resolução de problemas", "tutorial", "aplicativos" (i.e. processador de texto, banco de dados, planilha eletrônica, gráficos, hipertextos, telecomunicações) e, mais recentemente, "multimídia/hipermídia".

Um software do tipo "exercício e prática" revê um conteúdo que já foi apresentado ao aluno. Seu principal objetivo é a aquisição, desenvolvimento e aplicação de um conhecimento específico, não sendo uma boa ferramenta se a estratégia de ensino é enfatizar a análise e a síntese do conteúdo pedagógico. O tipo "tutorial" é usado para introduzir novos tópicos e conceitos para os alunos, que segue instruções diretas. $O$ tipo "exercício e prática" pode, por exemplo, ser usado após a apresentação de um "tutorial", depois, portanto, de o aluno ter adquirido o novo conhecimento para uma avaliação da aprendizagem.

Um software de "simulação" permite ao aluno realizar atividades das quais normalmente ele não poderia participar, dando-lhe a oportunidade de testar, tomar decisões, analisar, sintetizar e aplicar o conhecimento adquirido em situações reais. A "simulação" permite realizações de experiências que métodos convencionais de ensino, usualmente, não proporcionam, fazendo com que o aluno observe e tire conclusões sobre as 
conseqüências de suas ações e decisões. A "simulação" pode ser utilizada, por exemplo, após a aprendizagem de conceitos e princípios básicos do tema em questão. Pensando no ensino de Física, esse tipo de software pode vir a colaborar de maneira intensa, mergulhando o aluno em processos indutivos que possibilitem a compreensão de leis físicas, através do reconhecimento de algum padrão de comportamento de um sistema. Isso é possível pois, nessas atividades, pode-se isolar o sistema, eliminar interferências e trabalhar apenas com variáveis relevantes. No entanto, o professor, além de ter o domínio do conceito a ser abordado, deve ter também clareza das limitações e implicações de uma simulação.

Um software direcionado para a "solução de problemas" apresenta situações que estimulam o aluno a encontrar estratégias próprias para resolver o problema proposto. Neste processo, o aluno avalia e utiliza os conhecimentos já adquiridos que são específicos e necessários para finalizar com sucesso a tarefa proposta. Dentro da categoria "solução de problemas", estão as "linguagens de programação" como o LOGO, para ensino elementar, e o LISP e o PROLOG, para estudos mais avançados, geralmente ligados à inteligência artificial. Em alguns casos, o aluno, ao aprender a programar, desenvolve a capacidade de gerar e resolver problemas. Dessa forma, ele aprende fazendo e não apenas vendo e, como agente ativo, pode montar e programar seus próprios jogos e simulações.

Quanto aos "softwares/aplicativos", existe um consenso (Gasperetti, 2001) de que "editor de textos" (exemplo é o Word do pacote Microsoft), "editor/programa gráfico" (exemplo é o Excell do pacote Microsoft), "banco de dados" (exemplo é o Access do pacote Microsoft), "planilha eletrônica", "hipertexto" (exemplo é a programação flash e HTML), "telecomunicações" e "multimídia/hipermídia" são essencialmente interativos, e o StarOffice aplicações freewares) permitem a organização e o tratamento rápido dos dados introduzidos no computador, apresentando grande potencialidade para o uso na prática educacional, podendo, portanto, com criatividade, ser utilizados em diversas atividades curriculares. De modo geral, destacamos a importância desse tipo de programa para que se desenvolva, o hábito de registro de informações, no aluno, seja uma ficha literária, do resumo de 
uma aula e mesmo a construção de um gráfico a partir de dados coletados em algum experimento. Os usos destes aplicativos dão grande liberdade ao professor para adaptá-los dentro das necessidades de suas disciplinas curriculares.

O "editor de textos" permite que o aluno crie e edite um texto de um modo mais produtivo, pois facilita sua tarefa desde o rascunho até à forma final (Lucena, 1992). Um "editor/programa gráfico" permite uma nova forma de expressão do aluno, através de gráficos ou desenho de gravuras, desenvolvendo sua criatividade e suas manifestações artísticas. A "planilha eletrônica" permite que $\mathrm{o}$ aluno analise $\mathrm{e}$, rapidamente, modifique a representação visual de um dado através de gráficos e tabelas. $O$ "banco de dados" armazena informações que podem ser, a qualquer momento, recuperadas, analisadas, tabuladas e comparadas. A facilidade de manipulação proporciona uma rápida assimilação, permitindo a avaliação, análise e síntese.

O "hipertexto" desperta a curiosidade do aluno, levando-o à articulação e à avaliação do conhecimento adquirido pela capacidade de gerenciar desvios interativos que, de certo modo, transforma as estratégias de aquisição do conhecimento do aluno, permitindo que ele "navegue" pelas telas do programa, procurando as informações de acordo com a curiosidade, o interesse e a necessidade. "Telecomunicações" permitem que computadores "falem" com outros computadores interligados em rede. Essa ferramenta pode ser extremamente valiosa para a busca de informações fora dos limites da escola, enriquecendo conteúdos e gerando um conhecimento multidimensional. "As fontes de informação são inesgotáveis e as análises destas informações produzem a substância do pensamento crítico" (Lucena, 1997). Um ambiente "multimídia/hipermídia" se destaca por reunir todos os canais de interação e comunicação como som, texto, imagem, vídeo, animação, assim como um "hipertexto", transforma as estratégias metodológicas, proporcionando novas formas de aquisição do conhecimento. 
Para que um software seja utilizado com finalidade educacional ou em atividades curriculares, é necessário que sua qualidade, interface e pertinência pedagógica sejam previamente avaliadas de modo a atender às áreas de aplicação a que se destina e, principalmente, satisfazer às necessidades dos usuários, desenvolvendo a investigação e o pensamento crítico. Deve-se, portanto, "considerar como software educacional todo aquele que possa ser usado para algum objetivo educativo, pedagogicamente defensável, por professores e alunos, qualquer que seja a natureza ou finalidade para a qual tenha sido criado "(Lucena, 1992).

Atualmente existem vários softwares gerados com a finalidade de aplicação educacionais. Em especial, para o ensino de Física, encontra-se, por exemplo, Interactives Physics - que simula situações da mecânica newtoniana; Óptica-Senac ${ }^{5}$ - uma espécie de livro eletrônico que contém tópicos de Óptica Geométrica; Concepts on Line - um banco de dados que traz várias simulações de situações científica; Edison - que simula experiências sobre o Eletrodinâmica; Crocodille - que apresenta laboratórios virtuais, permitindo a utilização da simbologia específica; o Educandus ${ }^{6}$ programa tutorial composto por simulações e exercícios, entre tantos outros.

\subsection{0 professor diante do computador}

A utilização do computador pode ser feita de variadas formas e depende da postura dos professores. Portanto, compreender que relações o docente estabelece com essa máquina é importante. O microcomputador só será totalmente integrado ao processo ensino-aprendizagem quando o professor tiver uma outra postura, acreditando ser possível posicionar-se dentro do, provavelmente irreversível, processo de informatização da sociedade.

Assim, o uso do computador na escola só faz sentido na medida em que o professor, além de considerá-lo como uma ferramenta de auxílio motivadora à sua prática pedagógica, também tenha intimidade com ele, tornando-o, dessa forma, um instrumento renovador do processo ensino-

\footnotetext{
${ }^{5}$ Senac - Guia de software Edulink (1999)

${ }^{6}$ Sistema de ensino Educandus
} 
aprendizagem, que the forneça meios para o planejamento de situações e atividades simples e criativas e que, conseqüentemente, possa the proporcionar resultados positivos na avaliação de seus alunos e de seu trabalho.

A capacitação dos professores é, portanto, de fundamental importância para a integração do computador com as atividades escolares. Existe a necessidade de que entidades governamentais e mesmo as escolas se preocupem em proporcionar, além de laboratórios ou salas de informática, cursos para professores e, opcionalmente, para alunos, utilizando preferencialmente esse espaço da própria escola ou centros de treinamento, como os atuais Núcleo de Tecnologia Educacional (NTE), do Projeto Proinfo do MEC.

Ao introduzir computadores no processo educacional é preciso considerar que "as novas práticas são inventadas, construídas, conquistadas coletivamente, e não no isolamento individual" (Nóvoa, 1992). Então, torna-se necessária a associação de ações inovadoras a projetos pedagógicos expressos no comportamento coletivo - expressão do compromisso coletivo da comunidade educacional - constituídos por processos de ensino-aprendizagem e mesmo de pesquisa ao permitir a investigação, a análise, a reflexão e a depuração do processo de utilização dos computadores, reproduzindo o ciclo do construcionismo de Papert.

Segundo Correia (1991), "a instituição se distingue da organização por ser uma entidade em contínuo movimento dialético que 'se produz e se reproduz no conflito' entre a universalidade e a singularidade". Numa contradição, as inovações são compreendidas através dos conflitos que provocam com o sistema estabelecido e as possíveis rupturas. Começa, então, a ser atribuído às instituições um espaço autônomo "cuja configuração e funcionamento têm como elemento decisivo a ação e interação dos diferentes 'atores sociais' que participam de sua vida" (Nóvoa, 1995). Esses atores (professores, administradores, funcionários, alunos, pais etc.) deveriam ser os responsáveis pela definição de projetos pedagógicos que incluíssem a inserção de inovações. 
Quando a ênfase do projeto pedagógico fomenta o aprender e promove a autonomia do aluno, as mudanças tornam-se explícitas. Toda a comunidade escolar trabalha no desenvolvimento de projetos tornando-se produtora de conhecimento, construindo uma nova prática docente.

\subsection{A formação de professores em informática}

Segundo Moraes (1993), a informática na educação brasileira iniciase em 1971 com um seminário na Universidade de São Paulo, assessorado por um especialista da Universidade de Dartmouth/USA, com aquela discussão sobre o uso de computadores no ensino de Física. Durante toda a década de setenta, todas as atividades envolvendo informática em educação permaneceram nas universidades públicas, em projetos localizados. Em 1983, o governo federal cria o Projeto Educação com Computadores (EDUCOM), numa primeira ação oficial e concreta para levar os computadores até as escolas públicas brasileiras. Cinco universidades públicas abrigavam os centros-pilotos - Universidade Federal de Pernambuco (UFPE), Universidade Federal do Rio de Janeiro (UFRJ), Universidade Federal de Minas Gerais (UFMG), Universidade Federal do Rio Grande do Sul (UFRGS) e Universidade Estadual de Campinas (UNICAMP) - com recursos oriundos do Finep ${ }^{7}$, Funtevê $\hat{A}^{8}$ e do CNPq . Entre 1986 e 1987, o Comitê Assessor de Informática para a Educação de $1^{\circ}$. e $2^{\circ}$. graus (CAIE/Seps), do Ministério da Educação e Cultura (MEC), implanta os Centros de Informática Educacional (CIEs) buscando convênio com as Secretarias Estaduais e Municipais de Educação e a definição e organização de cursos de formação de professores.

Entre alguns esforços do governo para implantar a informática nas escolas públicas do ensino fundamental e médio, o projeto EDUCOM apresentou maior número de ações organizadas pela Secretária Especial de Informática. Outro programa, de projeção estadual apenas, foi "A escola de

\footnotetext{
${ }^{7}$ Financiadora de Estudos e Projetos

${ }^{8}$ Fundação Centro Brasileiro de Televisão Educativa

${ }^{7}$ Conselho Nacional de Desenvolvimento Científico e Tecnológico 
Cara Nova na Era da Informática", promovido pelo governo do Estado de São Paulo.

O Projeto EDUCOM tinha como objetivo geral incrementar a pesquisa multi-disciplinar, aplicando a informática nos ensinos fundamental e médio, sem a pretensão de informatizar a escola de imediato. Serviu de inspiração para que surgissem movimentos de informatização das escolas, tanto municipais quanto estaduais, além também, de certo modo, de fornecer subsídios para a criação, em 1995 do Projeto PROINFO Programa Nacional de Informática na Educação.

O projeto Proinfo é criado visando à formação dos Núcleos de Tecnologias Educacionais (NTEs) em todos os estados. Esses núcleos "são importantes estruturas descentralizadas de apoio ao processo de informatização das escolas" (Proinfo, 1997). Neles são capacitados os professores da rede pública e os técnicos de suporte na utilização da informática educativa (hoje são cerca de 243 NTE's), capacitando professores.

Conforme a página da Internet http//www.mat.unb.br/ed/MEC (09/02/99), o Proinfo é, na verdade, o "plano de Tecnologia Educacional do MEC". Esse plano conta com a parceria das secretarias estaduais, que buscam equipar eletronicamente as escolas públicas, visando, inicialmente, "alfabetizar" os alunos em informática e, após, incorporar o uso do computador ao processo de ensino-aprendizagem. Segundo seu Plano Global, as escolas públicas interessadas na informatização poderão fazer e enviar planos "individuais". Os planos são enviados primeiramente às Secretarias Estaduais de Educação (SEEs), que os enviarão posteriormente ao MEC para a avaliação a aprovação, buscando o estabelecimento de uma conexão entre MEC e SEE's, criando a Rede Nacional de Informática na Educação. O programa ainda está sendo implantado em todos os estados do território nacional, e a distribuição dos 100.000 computadores previstos será de acordo com o número de alunos matriculados em cada estado. As SEE's são responsáveis por criar os NTE's, com aproximadamente 50 escolas por núcleos, que também estarão conectadas à rede. Caberá, aos 
NTE's, assessorar as escolas quanto ao planejamento de seus planos individuais, bem como fornecer apoio técnico e pedagógico quando da implantação do plano. Assim, segundo http/www.mat.unb.br/ead/MEC (09/02/99), os NTE's serão responsáveis por:

"- sensibilizar e motivar as escolas para incorporação da tecnologia da telemática;

- apoiar o processo de planejamento tecnológico das escolas, para aderirem ao projeto estadual de informática na Educação;

- treinamento e reciclagem dos professores e das equipes administrativas das escolas;

- cursos especializados para as equipes de suporte técnico;

- apoio (help-desk) para resolução de questões técnicas, resultantes do uso do computador nas escolas;

- assessoria pedagógica para uso da tecnologia no processo de ensinoaprendizagem; e acompanhamento e avaliação local do processo de informatização das escolas".

O programa estadual paulista "A Escola de Cara Nova na Era da Informática" teve início em 1997 com a implantação de salas-ambiente em mais de duas mil escolas, tanto no ensino fundamental quanto no ensino médio (cerca de $30 \%$ do total de escolas estaduais). Paralelamente à implantação das salas-ambientes, professores e especialistas em educação foram treinados para se familiarizarem com o equipamento e poderem desenvolver seus próprios projetos de uso dos microcomputadores da escola. Ainda para apoiar os professores e as escolas, foram criados os Núcleos Regionais de Tecnologia Educacional (NRTE's), equipados com computadores, softwares educacionais e demais periféricos, para servirem como oficinas de divulgação das novas tecnologias. Os objetivos deste programa são "utilizar as tecnologias mais modernas para dar apoio ao ensino; enriquecer o processo de ensino-aprendizagem; tornar a escola mais atraente para os jovens; possibilitar pesquisas mais rápidas e dinâmicas, além de promover a integração das mesmas via Internet" (CENP, 1997). 
Entidades não governamentais também têm promovido atividades voltadas para o uso do computador na escola. A Microsoft, empresa que hoje comercializa uma linha de produtos, desenvolve o projeto IntelEducação para o Futuro, desde 2000. Inicialmente, com cursos de 48 horas exclusivos para formação de professores multiplicadores Intel Educação, idéia explicitada no tema "Educação para o Futuro com o suporte da Microsoft". Os cursos, realizados em 10 módulos, tiveram como objetivo formar professores para promover o aprendizado baseado na investigação tendo, como foco, integrar efetivamente a utilização de computadores aos seus currículos, de modo a resultar em melhoria na aprendizagem e nas realizações de seus alunos.

A proposta da Microsoft incluía (Candau, 2000):

"- a utilização efetiva da tecnologia na sala de aula;

- o enfoque no método de utilização da tecnologia por alunos e professores visando aumentar o aprendizado através de estratégias e ferramentas de pesquisa e comunicação;

- a ênfase na aprendizagem através de atividades práticas, criação de planos de unidade e ferramentas de avaliação, seguindo padrões tecnológicos e referências curriculares locais e nacionais;

- promover oportunidades para o envolvimento dos professores-autores através do acesso à tecnologia;

- incentivar os professores a adotarem trabalho em equipe, solução de problemas e participação nas revisões de suas unidades com seus colegas professores".

Os professores multiplicadores se envolveram no programa, primeiramente, como se fossem um professor participante e, depois, reaplicando as informações a outras turmas, tendo assim como expectativa uma participação de 40 horas de curso ministrado em laboratórios de informática e 8 horas de planejamento do curso, fazendo o desenvolvimento do Plano de Unidade e exemplos de produções e documentação de apoio ao professor, discutindo e refletindo as perguntas pedagógicas que aparecem no programa, compreendendo os requisitos do professor multiplicador e do professor participante. 
Trabalhar no eixo de professores multiplicadores pode ser um ganho à medida que se provoca um efeito cascata no ensino-aprendizagem, tendo, teoricamente, uma ampliação considerável do alcance educativo (ganho quantitativo). Caso a turma inicial de professores multiplicadores seja tal que os mesmos melhorem os métodos aprendidos, o ganho é mais uma vez apurado. Caso contrário, a amplitude quantitativa pode levar a um empobrecimento das idéias que se pretende discutir/ensinar (perda de qualidade).

De modo geral, seja uma proposta governamental ou não, uma proposta para formação docente em informática deveria, sem dúvida, ter como objetivo o domínio desse objeto tecnológico, seus softwares e a Internet. Mas, além disso, há a necessidade de se discutir novas e oportunas ações pedagógicas com o auxílio do computador, permitindo compreender um pouco mais o processo ensino-aprendizagem e seu próprio conhecimento. Cursos de formação docente são necessários para trocas de experiências profissionais, onde as informações compartilhadas colaboram para o desenvolvimento do trabalho individual.

Diversas iniciativas vêm sendo desenvolvidas em diferentes centros de formação e universidades, onde outros projetos e programas estudam a inserção da informática na educação, com resultados apresentados e discutidos em meio à comunidade acadêmica e em publicações em periódicos.

No próximo capítulo, será apresentado um levantamento feito junto às principais referências, entre eventos e publicações, da área de Educação em Física buscando compreender de que forma a formação docente em informática tem sido abordada no país. 


\section{UM PANORAMA DO ENSINO DE FÍSICA E A INFORMÁTICA}

Neste capítulo busca-se compreender como o computador tem sido utilizado no ensino de Física em nosso país e, em especial, que papel o professor assume frente a esse novo instrumento pedagógico e a esse novo processo de ensino-aprendizagem, produzindo um também novo conhecimento escolar e promovendo uma aprendizagem mais significativa em Física.

Para tal, foram analisadas as produções intelectuais apresentadas nos principais eventos e publicações da área nos últimos dez anos, com especial atenção ao Simpósio Nacional de Ensino de Física (SNEF), entre 1993 e 2003 (edições X, XI, XII, XIII , XIV e XV), à Revista Brasileira de Ensino de Física (RBEF - 1993 a 2002) e ao Caderno Catarinense de Ensino de Física ${ }^{10}$ (CCEF - 1993 a 2002).

Esses simpósios e periódicos, com participação de pesquisadores nacionais e internacionais, têm contribuído significativamente para reflexões e discussões das múltiplas experiências vivenciadas pelos seus participantes, que apresentam suas atividades de pesquisa, suas experiências de docência e/ou de outros projetos, constituem importantes veículos de divulgação de projetos e pesquisas em Educação em Física.

\subsection{O Ensino de Física e a Informática no SNEF}

O SNEF ocorre bienalmente e sua análise foi realizada através dos Cadernos de Programas e Resumos e, quando possível, verificando suas Atas. Na busca de um panorama global, procurou-se, dentre todos os trabalhos apresentados, aqueles que focalizassem a utilização do computador no ensino de Física, tentando compreender também o que significava, para o evento, o uso do computador na Educação em Física.

\footnotetext{
${ }^{10}$ A partir do ano 2002, o periódico passou a chamar-se Caderno Brasileiro de Ensino de Física.
} 
Normalmente os trabalhos nesse simpósio são agrupados em áreas ou sessões temáticas. Em alguns eventos, os trabalhos relacionados à informática contaram com uma área específica a eles dedicada. Porém, na ausência dessa área específica, os trabalhos com esse caráter foram apresentados em outras sessões tais como "materiais e métodos" ou "formação de professores", como, por exemplo, no XI SNEF. Mas, mesmo nas edições onde não houve sessões específicas, o conjunto de todos os trabalhos apresentados foi analisado.

Os trabalhos foram analisados em dois grupos. No primeiro grupo (grupo 1) foram analisados conjuntamente os temas das mesas redondas, palestras, conferências, encontros temáticos, cursos e oficinas oferecidos. No segundo grupo (grupo 2), com focos de pesquisa mais facilmente identificados, analisou-se os trabalhos apresentados em forma de comunicações orais e pôster. Nesse grupo, para identificar o uso do computador no ensino de Física, procurou-se uma maneira de identificar, nesses trabalhos, elementos e características particulares que permitissem compreender a sua natureza e enfoque principal. Esses diferentes elementos deram origem a três grandes eixos para a análise: I - Softwares e Aplicativos, II - Internet e III - Formação do Professor e o Computador.

Trabalhos destacados no primeiro eixo, softwares e aplicativos, são, por exemplo, os que relatam resultados de uma busca por softwares, que utilizam o microcomputador para coleta automática e interpretação de dados (por meio de hardware ou software), que mostram o desenvolvimento de softwares ou simplesmente atividades interativas com a função de ensinar a manusear com mais segurança o programa. Também aqui foram classificados trabalhos relacionados à aprendizagem por meio dos softwares, ou seja, aqueles preocupados com a forma de aplicação e com as atividades disponíveis no ambiente. Trabalhos como a análise e avaliação dos alunos diante de softwares também foram destacadas nessa classificação.

No segundo eixo, procurou-se verificar de que forma a Internet têm colaborado com o ensino de Física em termos de produção de páginas dinâmicas (homepages), com a criação de web-sites, com links para outras páginas, disponibilizando referências bibliográficas, textos, artigos, 
monografias e outros materiais de aplicação dirigidos não apenas ao ensino de Física, mas também à implantação de projetos (Uniescola, Escola Virtual e Escola do Futuro, entre outros). Enquanto elemento de alta interatividade e em função de sua possibilidade de propagação de conhecimento, a Internet potencializou a disseminação do ensino à distância, sendo a criação desses cursos também apresentados nos simpósios.

No eixo Formação do Professor e o Computador, buscou-se as produções que apresentassem uma reflexão diante da formação do professor, seja de natureza a identificar as suas visões sobre uso do computador na escola, seja quanto às possibilidades e formas da inserção da informática em sua prática pedagógica.

Com as caracterizações acima descritas, os simpósios são analisados a seguir.

\subsubsection{Simpósio Nacional de Ensino de Física}

O X SNEF (25 a 29 de janeiro de 1993), realizado em Londrina - PR, foi sediado na Universidade Estadual de Londrina, tendo como tema "Tempo de avaliação".

Dentre os trabalhos do grupo 1 , o evento proporcionou a apresentação 31 atividades, das quais nenhuma contemplou diretamente 0 tema Informática no ensino de Física. Foram oferecidos 22 cursos e oficinas, dos quais apenas um deles ${ }^{11}$, representando $4 \%$, teve como foco as novas tecnologias no ensino de Física.

Dentre os trabalhos do grupo 2, de um total de 176 trabalhos apresentados, $10(6 \%)$ relacionavam o uso do computador no ensino de Física. Entre esses trabalhos foi possível verificar que todos podem ser classificados no eixo I, Softwares e Aplicativos, sendo observado que, quando se pensava na utilização dos computadores no ensino de Física, o foco estava nas simulações e na utilização do software.

O histograma a seguir sintetiza o número de trabalhos para cada eixo de análise aqui proposto. Os eixos Internet e Formação de Professores

\footnotetext{
11 Todos os trabalhos relacionando o uso do computador ao ensino de física são apresentados em anexo, através de seus códigos e nomenclaturas.
} 
e o Computador não se constituíam temas de pesquisa para a área de ensino de Física.

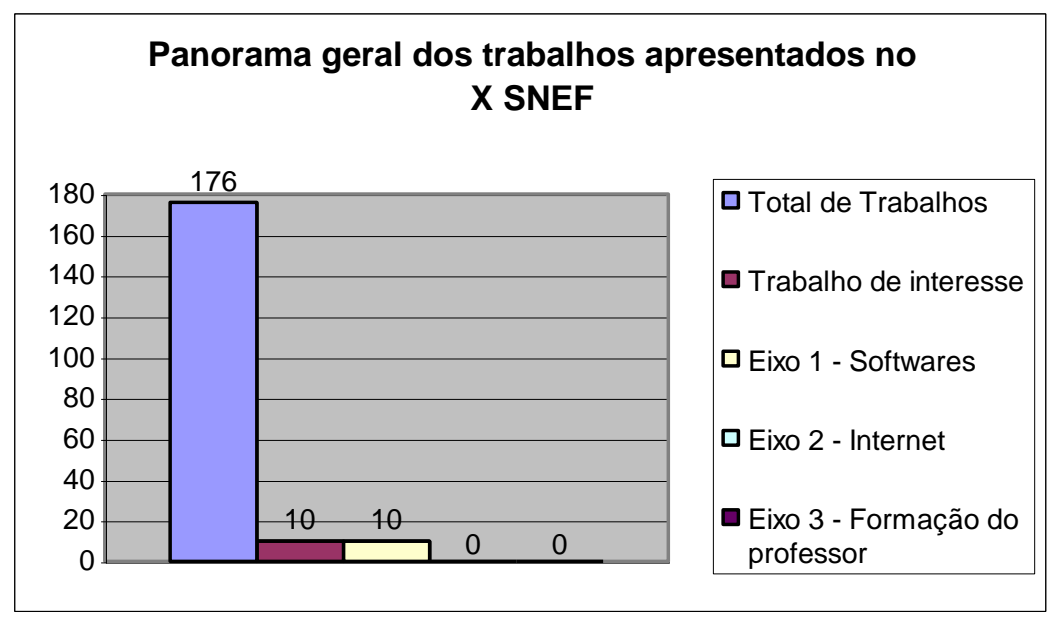

\subsubsection{Simpósio Nacional de Ensino de Física}

O XI SNEF foi sediado pela Universidade Federal Fluminense (UFF) entre 23 e 27 de janeiro de 1995, em Niterói - RJ, com o tema "Tempo de Mudança".

Entre palestras, mesas redondas e encontros temáticos e atividades do primeiro grupo foram 22 apresentações com apenas uma mesa redonda, contemplando diretamente o tema "Informática no ensino de Física", discorrendo sobre a Internet. Entre os 43 cursos e oficinas oferecidos, 5 $(12 \%)$ oficinas abordavam o tema informática e, na maioria das vezes, com a produção de materiais.

Em relação aos painéis e comunicações orais, de um total de 130, 5 trabalhos (4\%) abordavam o uso do computador no ensino de Física, sendo que 3 deles (60\%) foram classificados no eixo I, Softwares e Aplicativos, e 2 trabalhos (40\%) se encaixavam no eixo II, abordando a criação de páginas dinâmicas, analisando e discutindo educação a distância (EAD). No terceiro eixo não encontramos nenhum trabalho nesse evento, conforme sintetiza o histograma abaixo. 


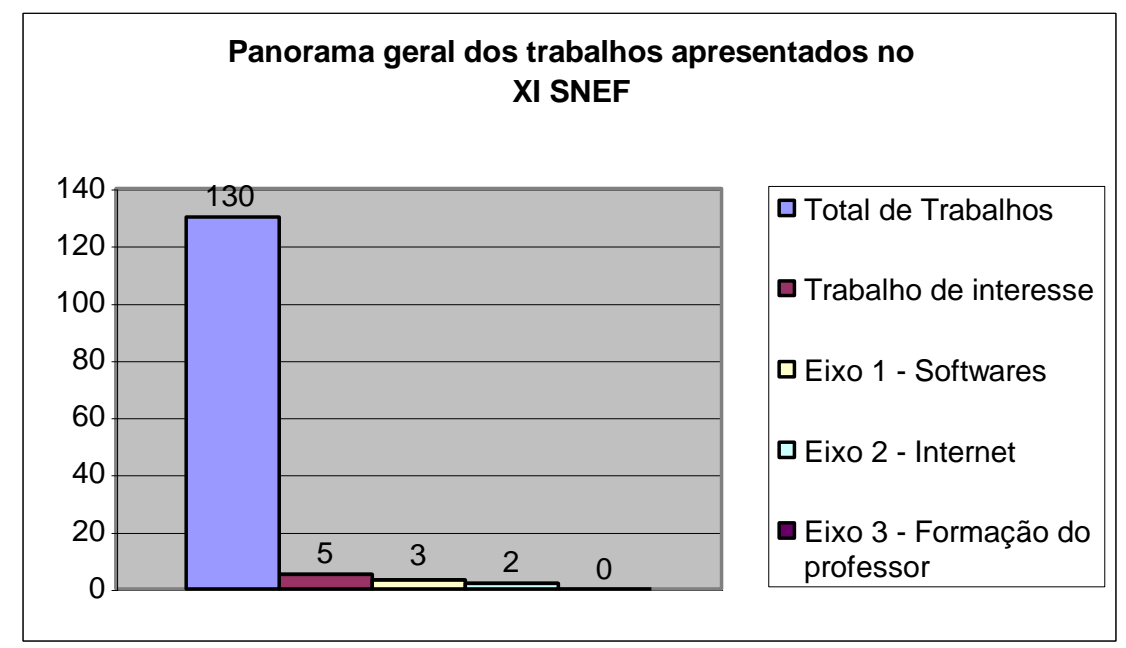

\subsubsection{Simpósio Nacional de Ensino de Física}

O XII SNEF ocorreu de 27 a 31 de janeiro de 1997, em Belo Horizonte - MG, sediado pela Universidade Federal de Minas Gerais (UFMG), tendo como tema "Novos horizontes: educação permanente, novas tecnologias e inovações curriculares"

O evento proporcionou 35 apresentações do grupo 1 , das quais 4 contemplavam diretamente o tema "Informática no ensino de Física". Entre cursos e oficinas, foram ofertadas 63 atividades, sendo que 09 (14\%) estavam relacionadas à informática.

No grupo 2, entre comunicações orais e painéis, de um total de 222 trabalhos apresentados, 22 deles (10\%) relacionavam o uso do computador ao ensino de Física. Dentre esses trabalhos, é possível verificar 20 trabalhos (91\%) no eixo I, Softwares e Aplicativos, dos quais 2 discutiam abordagens teóricas sobre a aprendizagem. No eixo II, Internet, 2 trabalhos (9\%) foram apresentados. O eixo III, Formação do Professor e o Computador, não foi contemplado nesse evento.

O gráfico abaixo representa o número de trabalhos apresentados em relação ao uso do computador no ensino de Física e o número de trabalhos apresentados em cada eixo de análise aqui proposto. 


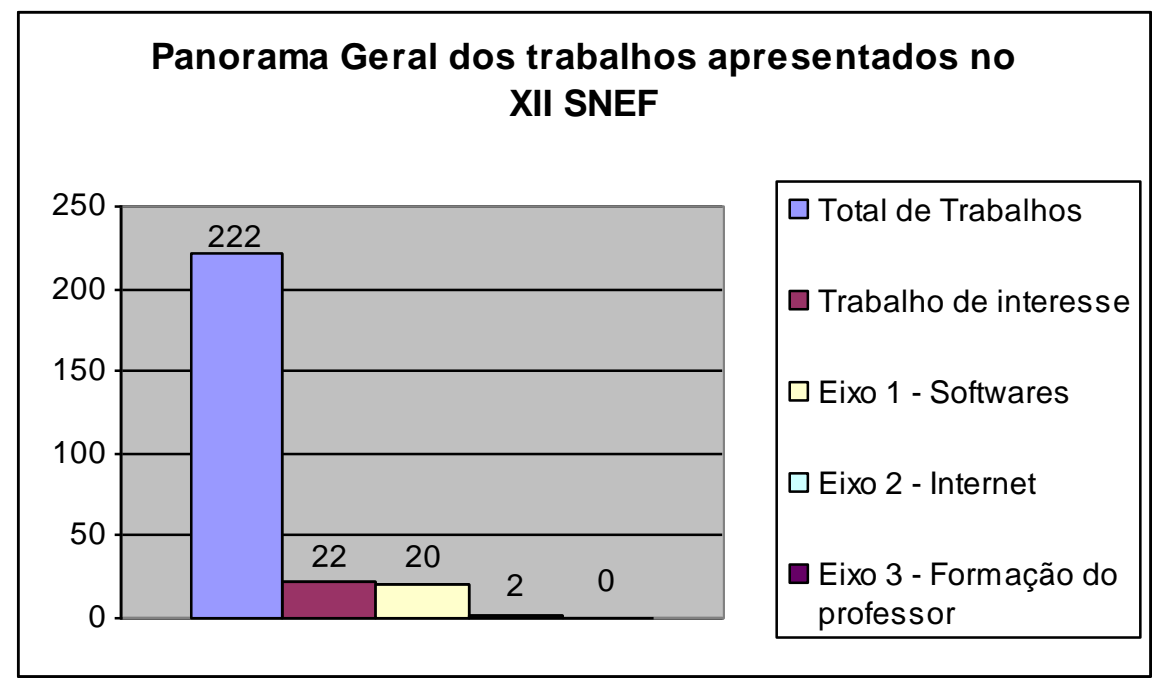

\subsubsection{Simpósio Nacional de Ensino de Física}

O XIII SNEF foi realizado na Universidade de Brasília (UnB), Brasília - DF, de 25 a 29 de janeiro de 1999 com o tema "O ensino de Física: em busca de sua identidade".

O evento proporcionou a apresentação de 24 atividades dentre os trabalhos do grupo 1. Duas delas contemplavam diretamente o tema informática no ensino de Física. Foram oferecidos, neste evento, 38 cursos e oficinas, dos quais 3 deles (8\%) eram oficinas relacionadas ao laboratório de informática.

Em relação às comunicações orais, de um total de 184 trabalhos apresentados, 27 (14\%) abordavam o uso do computador no ensino de Física. É possível classificar 17 trabalhos (63\%) no eixo I, Softwares e Aplicativos e 8 trabalhos (30\%) no eixo II, Internet, novamente abordando a criação de páginas dinâmicas e fazendo análise e discussão da educação a distância (EAD). No eixo III, Formação do Professor e o Computador, foram apresentados apenas 2 trabalhos, representando $7 \%$ do total dos trabalhos que relacionavam o uso do computador ao ensino de Física. 
O gráfico a seguir faz uma comparação quantitativa entre os

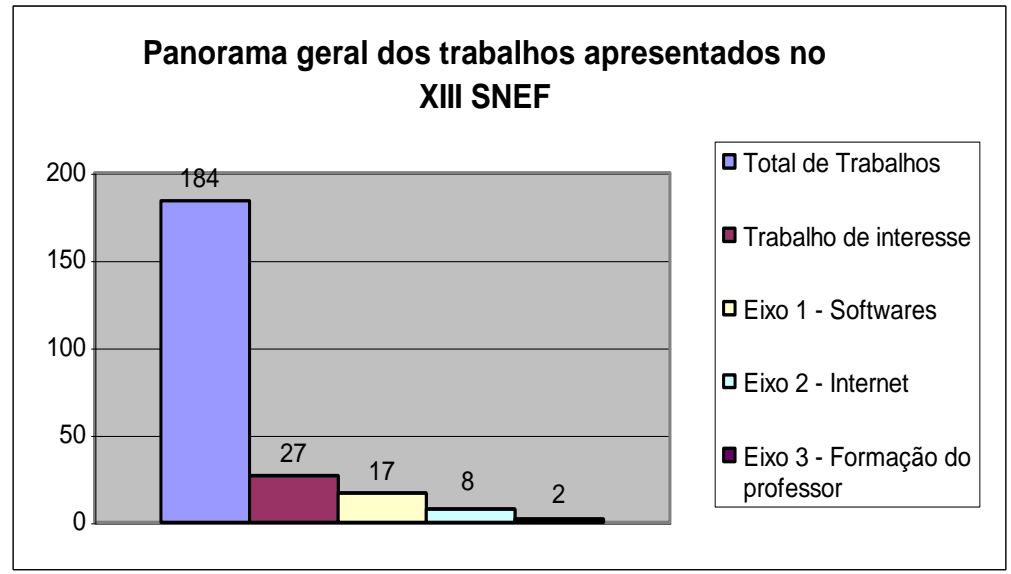

números observados.

\subsubsection{Simpósio Nacional de Ensino de Física}

A Universidade Federal do Rio Grande do Norte, em Natal, sediou o XIV SNEF entre os dias 02 e 06 de julho de 2001' O tema central foi "Educação Científica, cultura e qualidade de vida".

Sem acesso ao caderno de resumos ou às atas, conseguindo somente poucas informações nos resumos disponíveis na Internet ${ }^{12}$, a maioria dos trabalhos foi classificada somente pelos seus títulos.

Entre palestras, mesas redondas e fórum debates, trabalhos do grupo 1, o evento proporcionou a apresentação de 34 atividades. Dentre essas atividades, somente uma mesa redonda contemplava diretamente 0 tema "Informática no ensino de Física". Foram oferecidos 52 cursos e oficinas, dos quais 7 deles (13\%) eram relacionados ao laboratório de informática.

Em relação ao grupo 2, de um total de 226 trabalhos apresentados em forma de painel, 19 deles (9\%) foram relacionados ao assunto do uso do computador no ensino de Física.

\footnotetext{
${ }^{12}$ http://community.webshots.com/album/18407894kecAPfJmVT
} 
Dentre aqueles que tratavam da informática no ensino de Física, um número significativo de trabalhos - 63\% (12 trabalhos) - representavam no eixo I, Softwares e Aplicativos. No eixo II, Internet, 6 (32\%) abordaram a criação de páginas dinâmicas, fazendo análise e discussão da educação à distância (EAD). No eixo III, Formação do Professor e o Computador, foi apresentado 1 trabalho, representando $5 \%$ do total.

O gráfico abaixo representa a análise feita.

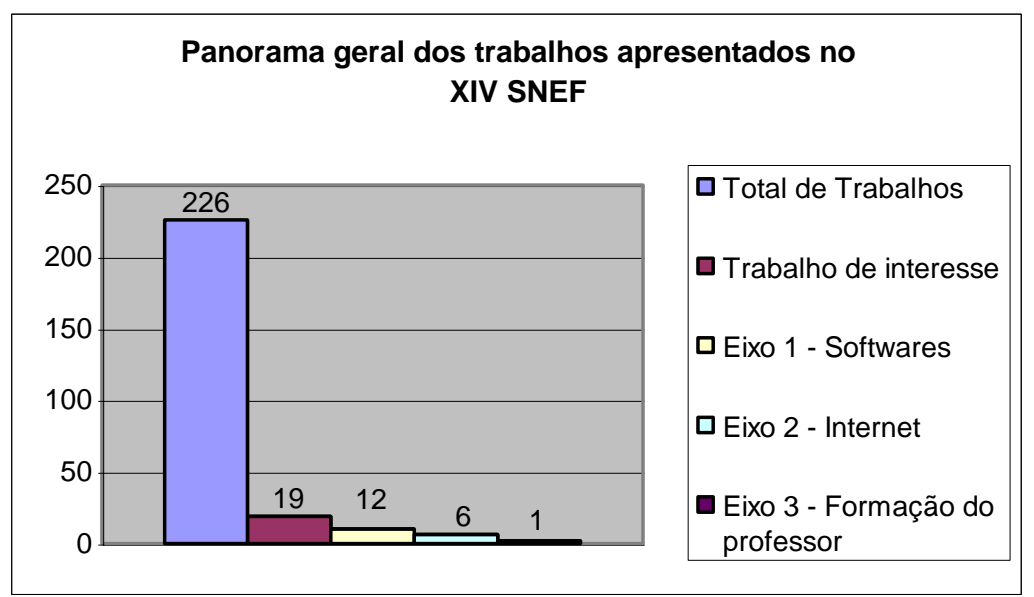

\subsubsection{Simpósio Nacional de Ensino de Física}

O mais recente evento, o XV SNEF, foi realizado na Universidade Federal do Paraná (UFPR) e no Centro Federal de Educação Tecnológica do Paraná (CEFET-PR), em Curitiba - PR, entre 21 e 26 de março de 2003, tendo como tema "O ensino de Física: presente e futuro".

Entre palestras, mesas redondas e encontros temáticos, os trabalhos do grupo 1 totalizaram 27 apresentações, das quais uma palestra e uma mesa redonda que contemplavam diretamente o tema "informática e novas tecnologias". De um total de 64 cursos e oficinas oferecidos, 11 deles (17\%) eram oficinas relacionadas ao laboratório de informática.

Em relação às comunicações orais, de um total de 392 trabalhos apresentados, 50 deles (11\%) eram relacionados ao assunto do uso do computador na Educação em Física.

A análise mostra uma forte tendência ao eixo I, Softwares e Aplicativos, onde, dos 38 trabalhos (76\%) classificados, 28 deles 
destacavam a produção, simulação e utilização de softwares. Os 10 trabalhos restantes relacionados a softwares discutiam de uma forma geral a avaliação e aprendizagem a partir dos mesmos.

No eixo II, Internet, 7 trabalhos (14\%) foram responsáveis pela criação de páginas dinâmicas, fazendo análise e discussão da educação a distância (EAD). No eixo III, Formação do Professor e o Computador, foram apresentados 5 trabalhos, representando $10 \%$ do total dos trabalhos.

O gráfico abaixo mostra o número de trabalhos apresentados, com a síntese da análise aqui proposta.

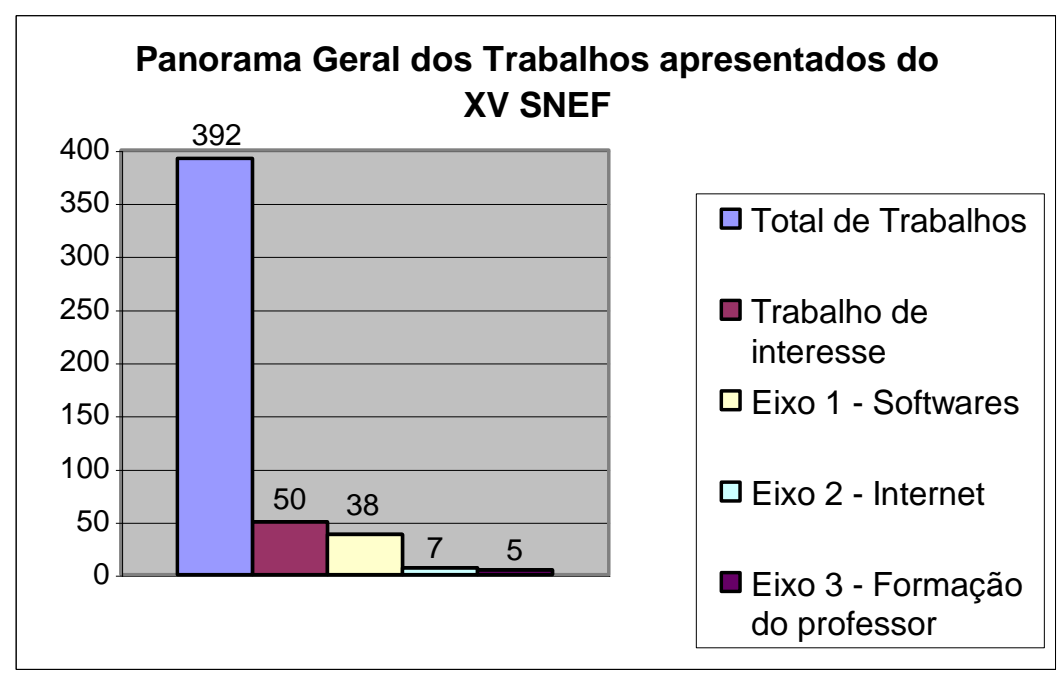

\subsection{O Ensino de Física e a Informática na RBEF e no CCEF}

Para a análise dos dois periódicos selecionados (RBEF e CCEF), foram resgatadas todas as edições de 1993 a 2002. Analisando primeiramente os índices das publicações, foram separados os artigos ${ }^{13}$ que relatavam o uso do computador no ensino de Física, buscando compreender, de modo geral, o foco principal dos trabalhos selecionados, especialmente daqueles que tratavam da formação do professor.

\footnotetext{
${ }^{13}$ Os títulos dos artigos selecionados para análise estão em anexo.
} 
Sendo editada bimestralmente pela Sociedade Brasileira de Física, neste período de dez anos, foram publicados 40 números da $\mathrm{RBEF}^{14}$, totalizando 463 artigos. Dentre estes artigos, 35 tratavam do uso do computador em ensino de Física. Já o CCEF, revista sob responsabilidade do Departamento de Física da Universidade Federal de Santa Catarina, editado quadrimestralmente, conta com três edições anuais. Assim, foram analisados 30 números, totalizando 222 artigos publicados ${ }^{15}$. Dentre esses artigos, 9 discutiam o uso do computador no ensino de Física.

Somando os artigos da RBEF e CCEF, temos 685 artigos no total, sendo a informática no ensino de Física, objeto de análise de apenas 44 (6\%) deles. De uma forma geral, esses artigos centram suas discussões na produção de softwares, na aprendizagem através dos softwares, nas simulações, na criação e divulgação de páginas da Internet e na análise e discussão da educação à distância (EAD).

Para a grande maioria dos artigos selecionados, a principal questão é a produção de softwares, discutindo possibilidades, limitações e formas de utilização. Apesar de muitos trabalhos defenderem a aprendizagem através do uso do computador, apenas um autor (Rezende, 2001) tentou avaliar um sistema hipermídia para facilitar a reestruturação conceitual. Nenhum artigo cujo foco envolvesse a questão do computador e da formação docente foi encontrado.

Um levantamento feito por Rosa (1995), em artigos de periódicos nacionais e internacionais de 1979 a 1992 (incluindo a RBEF e CCEF), a fim de analisar as potencialidades do uso de computadores no ensino de Física, classificou em oito categorias os artigos publicados. Numa comparação destas categorias com o presente levantamento, apesar dele ter encontrado e discriminado diferentes formas de utilização do computador, a maioria dos artigos focava a utilização dos softwares, da mesma forma que nesse levantamento dos últimos dez anos. A formação de professores em seu estudo não deixou de ser analisada, na categoria por ele denominada

\footnotetext{
${ }^{14}$ É importante destacar que uma edição da RBEF (Volume 24, № 2 de Junho 2002) foi destinada especialmente aos trabalhos relacionados com a utilização dessas novas tecnologias na área de física.

${ }^{15} \mathrm{Na}$ contagem dos artigos, não foram consideradas as sessões Editorial, Informes, Pense e Responda, Comunicações e Resenhas.
} 
"Outros". Porém, somente um trabalho com esse enfoque foi encontrado (Rosa; 186).

Considerando que Rosa têm em sua pesquisa dados relativos a periódicos de 1979 a 1992, e que esse levantamento buscou informações de 1993 até 2002, pode-se perceber não ocorreram mudanças muito significativas na natureza dos trabalhos produzidos pela área de ensino de Física no Brasil.

\subsection{Um quadro comparativo}

O levantamento feito junto às principais referências de ensino de Física, sejam os SNEFs, sejam os artigos publicados na RBEF e no CCEF permite uma primeira análise quantitativa na tentativa de compreender que contribuições esses últimos dez anos de pesquisa têm trazido à área.

\begin{tabular}{|c|c|c|c|}
\hline SNEF & $\begin{array}{l}n^{\circ} \text { total de palestras e } \\
\text { mesas redondas (MR) }\end{array}$ & $\begin{array}{c}n^{\circ} \text { de palestras e } \\
\text { MR de interesse }\end{array}$ & $\%$ \\
\hline$X$ & 31 & 0 & 0 \\
\hline$X I$ & 22 & 1 & 5 \\
\hline$X I I$ & 35 & 4 & 11 \\
\hline$X I I$ & 24 & 2 & 3 \\
\hline$X I V$ & 30 & 1 & 7 \\
\hline$X V$ & 27 & 2 & \\
\hline
\end{tabular}

No caso dos simpósios, em relação aos trabalhos do grupo 1 (palestras, conferências, mesas redondas e encontros temáticos), observase uma oscilação muito grande, em termos percentuais, no número de trabalhos de interesse selecionados. Porém, a partir do XI SNEF (1995), a questão da Informática no ensino de Física esteve sempre presente, embora mantendo uma oscilação percentual, refletida num aumento de trabalhos no XII SNEF e um dos menores percentuais de publicações no XIV SNEF, contrariando expectativas de tendência de aumento ou, no mínimo, de manutenção do percentual de atividades.

Quantitativamente, ainda analisando o grupo 1, o XV SNEF concentrou o maior percentual de trabalhos de interesse. 


\begin{tabular}{|c|c|c|c|}
\hline SNEF & $\begin{array}{c}n^{\circ} \text { total de oficinas } \\
\text { e cursos }\end{array}$ & $\begin{array}{c}n^{\circ} \text { de oficinas e } \\
\text { cursos de interesse }\end{array}$ & $\%$ \\
\hline$X$ & 22 & 1 & 4 \\
\hline$X I$ & 43 & 5 & 12 \\
\hline$X I I$ & 63 & 9 & 14 \\
\hline$X I I I$ & 38 & 3 & 8 \\
\hline$X I V$ & 52 & 7 & 13 \\
\hline$X V$ & 64 & 11 & 17 \\
\hline
\end{tabular}

Em relação aos trabalhos do grupo 2 (comunicações orais e pôsteres) verifica-se também oscilações percentuais nesses dez anos analisados. Apesar disso, é notório o aumento no número de trabalhos dessa natureza nos últimos quatro simpósios. Pela tabela abaixo, pode-se inferir uma tendência de aumento, em termos percentuais, de trabalhos focalizando a Informática no ensino de Física.

\begin{tabular}{|c|c|c|c|}
\hline SNEF & $\begin{array}{c}n^{\circ} \text { total de comunicações } \\
\text { orais e pôsteres } \\
\text { apresentados }\end{array}$ & $\begin{array}{c}n^{\circ} \text { de comunicações orais } \\
\text { e pôsteres de interesse }\end{array}$ & $\%$ \\
\hline$X$ & 176 & 10 & 6 \\
\hline$X I$ & 130 & 05 & 4 \\
\hline$X I I$ & 222 & 22 & 10 \\
\hline$X I I I$ & 184 & 27 & 15 \\
\hline$X I V$ & 226 & 19 & 8 \\
\hline$X V$ & 392 & 50 & 13 \\
\hline
\end{tabular}

Já em relação à distribuição desses trabalhos dentro dos respectivos eixos propostos para análise, dentre os trabalhos de interesse selecionados, o gráfico seguinte evidencia uma forte tendência do eixo I (75\%). Nestes 10 anos analisados, os trabalhos envolvendo Softwares e Aplicativos sempre apareceram em maior número. No primeiro simpósio analisado, o X SNEF, todos os trabalhos que envolviam o uso do computador estavam centrados no desenvolvimento de softwares, focando principalmente as simulações. 


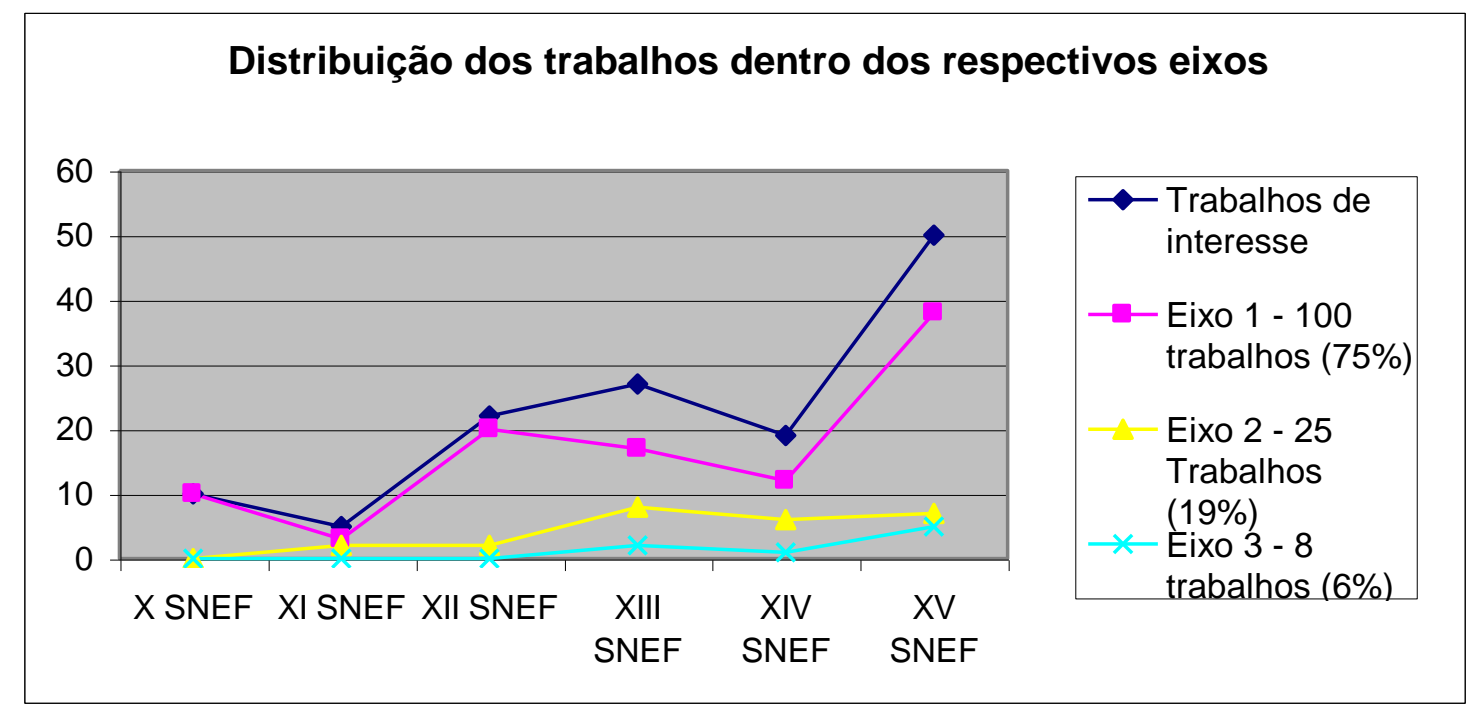

É importante destacar que, dentro do conjunto de todos os trabalhos do eixo 1, de um total de 100 trabalhos encontrados, somente 12 (12\%) traziam reflexões acerca da aprendizagem do aluno com uso de softwares.

Nos periódicos analisados, a grande maioria dos artigos encontrados também diziam respeito à produção e formas de utilização dos softwares.

Isso indica que há uma preocupação da área de ensino de Física principalmente em desenvolver, divulgar e estudar formas de utilização dos softwares; sendo que uma análise do processo de ensino-aprendizagem envolvido parece ser ainda bastante tímida, tendo se revelado nos eventos apenas mais recentemente.

Já em 1995, Rosa alertava que "... os computadores estão sendo utilizados indiscriminadamente sem que haja uma preocupação com a avaliação dos resultados obtidos" (ROSA; 188). Em sua pesquisa, os trabalhos analisados não evidenciavam "... a confiança de que um programa de simulação seja mais eficiente, sob o ponto de vista da aprendizagem conceitual, do que um experimento de laboratório bem elaborado e explorado" (ROSA;188).

A preocupação com a aprendizagem conceitual é também destacada por Rezende (2001), que desenvolveu uma pesquisa tentando aproveitar o potencial educacional dos sistemas hipermídias para atuar significativamente frente às dificuldades conceituais de estudantes. Apesar 
de observar ganhos na reestruturação conceitual dos estudantes, a autora destaca que ainda assim “... não houve evidências conclusivas de que os efeitos desejados sobre a reestruturação conceitual deveram-se especificamente ao desenho instrucional utilizado" (REZENDE; 212). Reforça-se assim a importância de se desenvolver trabalhos nessa linha.

No eixo Internet, observa-se que houve uma maior preocupação no XIII SNEF. Acredita-se que o aumento do número de trabalhos relacionados à rede mundial de computadores esteja associado a maior divulgação e acessibilidade da Internet nesse período, e, desde então, ela passou a ser utilizada como mais uma ferramenta para fazer pesquisas, consultas etc.. A maioria dos trabalhos divulgados no XIII SNEF indicava que saber trabalhar com a Internet, ou seja, conhecer suas ferramentas básicas, como acessar uma homepage, enviar e receber e-mails, participar de listas de discussão etc., seria necessário para a formação do professor. Já os trabalhos mais recentes preocupam-se com o ensino à distância.

Embora mais recentemente as relações estabelecidas pelo professor com o computador sejam objeto de pesquisa, somente 8 dos trabalhos de interesse se preocupam com a formação docente em informática. De uma forma geral, 3 desses trabalhos preocupam-se com a formação inicial do professor, enfocando o perfil de alunos de licenciatura (iniciantes e concluintes) e verificando as novas e diferentes interações/mediações que podem ser produzidas em torno desse novo espaço pedagógico. Os outros 3 trabalhos procuram verificar e fazer levantamentos de como vêm ocorrendo a formação continuada e a preparação dos professores já atuantes. Um dos trabalhos, inclusive, busca fazer a construção e análise de um planejamento utilizando um software educativo. O restante (2) busca verificar as interações através da Internet, utilizando os meios multimídias, homepages e e-mails para a realização de projetos de ensino, analisando a potencialidade de uma experiência em educação à distância. Essas discussões, abordadas somente após o XIII SNEF, vêm, timidamente, aumentando ano após ano.

Resgatando os resultados de Rosa (1995), que tendo analisado revistas desde 1979 a 1992 citou apenas um artigo envolvendo treinamento 
de professores, também a análise dos periódicos revelou essa lacuna quando se fala em informática no ensino de Física, pois nenhum artigo sobre a formação docente em informática foi encontrado.

Esse panorama traçado através das produções acadêmicas em eventos e periódicos indica que há uma grande preocupação em disponibilizar recursos (softwares e páginas dinâmicas) e ensinar os professores a utilizá-los. Porém ainda é bastante tímida a preocupação em estudar e tentar compreender o professor enquanto um sujeito nesse processo, o sujeito que poderá realmente levar todos esses recursos tecnológicos à sala de aula, utilizando-os como mais uma ferramenta, ou explorando as suas potencialidades que ainda estão sendo discutidas e desveladas.

Não que o estudo e desenvolvimento de softwares e páginas dinâmicas não sejam importantes; pelo contrário, somente dispondo de muitos e diferentes materiais, se terá condições de estudar suas potencialidades. Porém, é importante reforçar o estudo das percepções do professor em relação a esse mundo que vem se abrindo a sua frente, conforme lembra também Veit (2002;95), "além da tecnologia de qualidade, do entorno docente, de práticas educacionais embasadas em pesquisas educacionais, há que se investir no professor, cuja resistência e dificuldade de aprendizagem nesta área podem ser bem maiores do que as do estudante".

Quais seriam os anseios dos docentes, seu imaginário, sua postura frente às novidades da informática e a esse novo universo que se abre? $\mathrm{O}$ que eles conhecem e pensam deste universo? As reflexões sobre questões desse tipo são importantes para uma efetiva incorporação dos recursos da informática no ensino de Física. Nesse sentido, no capítulo seguinte, buscase elementos para essa reflexão sobre as respostas dadas por professores de Física do ensino médio a algumas questões dessa natureza. 


\section{UTILIZAÇÃO E COMPREENSÃO DO COMPUTADOR: UM OLHAR DO PROFESSOR DE FÍSICA}

Pelo panorama descrito no capítulo anterior, apesar das muitas discussões sobre objetivos, propostas e formas de utilização de microcomputadores permearem o ensino de Física, percebe-se que muitos trabalhos buscam soluções e avaliações para aplicativos (softwares) e que estão intimamente ligados com o questionamento através de sua aplicação e utilização. Em alguns desses trabalhos, a preocupação central focava a aprendizagem do ponto de vista do aluno. Outros trabalhos se propuseram a discutir sobre a Internet, ora como página dinâmica, ora como somente mais um recurso didático utilizando suas ferramentas (www, e-mail, chat, listas etc.). Mas, pouco se comenta sobre o ponto de vista dos professores a esse respeito ou mesmo sobre sua formação.

Esta parte do trabalho procura investigar as idéias dos professores de Física acerca do uso do computador em geral e, em particular, da Internet, mais especificamente, na escola.

Essa pesquisa foi realizada em duas etapas. Na primeira etapa, procurou-se verificar o conhecimento e a familiaridade do professor no espaço da informática, identificando, por exemplo, sua freqüência de acesso às páginas na Internet, o uso do correio eletrônico ou sua participação numa lista de discussão. Na segunda etapa, que complementa a primeira, a pesquisa foi direcionada mais especificamente para a educação e procurouse identificar a visão do professor sobre o computador na escola, seja com relação aos objetivos de seu uso, seja com relação às possibilidades e formas de sua inserção na prática pedagógica. 


\section{Etapa I - O professor no espaço da informática}

Dessa primeira etapa da pesquisa participaram quarenta e quatro (44) professores de Física da rede estadual de ensino da cidade de São Paulo. Esses professores, assessorados pelo Grupo de Reelaboração do Ensino de Física (GREF), participavam de encontros semanais realizados pela Diretoria Regional de Ensino (DRE - Zona Leste II), no último trimestre de 1999.

$\mathrm{Na}$ faixa etária entre 38 e 46 anos, tendo em média mais de 5 anos de experiência lecionando a disciplina de Física, um número considerável desses professores já havia compartilhado o seu tempo dando aulas também em outras disciplinas como Matemática, Química e Biologia. Sua formação era bastante diversificada, como licenciatura em Química, Biologia, Física e um número muito grande em Matemática. No entanto, na época da pesquisa, todos estavam atuando como professores de Física. Havia um professor que fugia desse perfil: com formação recente em Física, lecionava esta disciplina há apenas dois meses.

A tomada de dados foi realizada através de um questionário dirigido, contendo doze perguntas e aplicados no final de um encontro. A participação foi voluntária, mas a totalidade dos participantes do encontro contribuiu respondendo ao questionário. $O$ material para análise resultou num conjunto de respostas, algumas apenas com respostas afirmativas ou negativas e outras com explicações ou justificativas. Utilizando todas essas diferentes formas de respostas, principalmente das primeiras, é que serão extraídos os elementos para a análise das respostas.

\section{Características do instrumento de tomada de dados}

Para extrair elementos significativos sobre a relação do professor com elementos da informática, foi elaborado um questionário estruturado, contendo doze (12) questões abertas.

As duas primeiras questões eram gerais com o intuito de investigar a visão pessoal do professor sobre microcomputadores e, em particular, sobre a Internet, através de características ou elementos identificados por 
ele como relevantes e contidos em suas respostas. Embora as perguntas tenham sido formuladas em aberto, através de expressões como "O que você acha..." ou "O que vem à sua cabeça ...", esperavam-se respostas que fizessem referência ao papel dessas tecnologias na sociedade e também em situações de aprendizado e de comunicação entre pessoas, de serviços etc.:

Q1- O que você acha do computador? Você utiliza?

Q2- O que vêm à sua cabeça quando se fala em Internet?

Com as questões 3, 4 e 6, procurou-se verificar se o professor já tinha usado Internet e também investigar as possíveis reflexões, relações e observações que o professor tem sobre esse instrumento (processo de Internet e democracia) e a sua compreensão em relação a ele, com perguntas sobre a forma de comunicação utilizada na Internet (diferenças entre telefone e Internet). Assim, poderia ser possível verificar se realmente o professor tinha ou não domínio de algumas ferramentas consideradas básicas para um usuário de computador:

Q3- Poderíamos dizer que o funcionamento da Internet é igual a de um telefone? Por quê?

Q4- A Internet é democrática? Qual é sua opinião?

Q6- A Internet parece que veio para dominar e ela oferece possibilidades de acesso a milhões de páginas com os mais diversos temas e conteúdos e acredita-se que tudo que se procura, encontra-se. O que você pensa disso? Você acredita que podem existir muitas páginas a respeito de Ciência?

Para complementar as possíveis reflexões do professor acerca do uso das novas tecnologias, como o computador, com a questão 5 procurouse obter subsídios sobre a relação ou não entre avanço tecnológico e alienação:

Q5- Comente a frase abaixo: 
"As novas tecnologias, ao mesmo tempo que permitem um avanço significativo das comunicações entre homens, simultaneamente os aliena."

Junto a essas questões, com perguntas diretas sobre utilização ao não da rede através de homepage, Internet, listas de discussões, new groups e chat (questões 7, 8, 9, 10 e 11), buscava-se mais elementos sobre o uso e conhecimento pessoal do professor sobre os microcomputadores. $\mathrm{O}$ questionário utilizado encontra-se no Anexo 3.I.1.

Na tentativa de compreender quais termos ligados à tecnologia da informação eram conhecidos pelos professores, no questionário havia um quadro para que uma seleção fosse feita (assinalada) e também um espaço livre para manifestações, seja sobre o que eles gostariam de conhecer sobre a informática, seja dando sugestões e fazendo comentários gerais.

\section{Análise das respostas}

As respostas dos professores foram analisadas de duas formas: uma primeira, mais geral, através de respostas diretas, do tipo sim e não, na tentativa de se verificar que conhecimento o professor tem sobre as ferramentas que o computador oferece, como a Internet, homepage etc., e uma segunda, mais detalhada, através das justificativas ou considerações apresentadas pelos professores, na tentativa de extrair os significados das respostas.

As respostas às questões 1, 7 e 8, que tratavam, respectivamente, se o professor utilizava computador, se ele já visitou homepage e se ele já trocou mensagens via e-mail, oferecem um primeiro panorama da relação que o professor estabelece com a informática. Os resultados estão apresentados nos quadros abaixo.

Se o professor utiliza computador

SIM: $31(70 \%) \quad$ NÃO: $8(18 \%) \quad$ NÃO RESPONDEU: 5 $(11 \%)$ 


\begin{tabular}{|c|c|c|}
\hline \multicolumn{3}{|c|}{ Se o professor visitou homepage } \\
\hline $\begin{array}{l}\text { SIM: } 24(55 \%) \\
(5 \%)\end{array}$ & NÃO: $18(41 \%)$ & NÃO RESPONDEU: 2 \\
\hline
\end{tabular}

\begin{tabular}{|cc|}
\hline \multicolumn{2}{|c|}{ Se o professor trocou mensagens via e-mail } \\
\hline $\begin{array}{c}\text { SIM: } 12(27 \%) \\
(7 \%)\end{array}$ & NÃO: $30(68 \%)$ \\
\hline
\end{tabular}

Embora cerca de $70 \%$ dos professores afirmassem que utilizavam o computador, apenas $55 \%$ já visitaram alguma homepage, e o que é surpreendente, é que apenas $27 \%$ deles trocaram mensagens via e-mail. Consistentemente, verificou-se que os professores que já trocaram mensagens via e-mail ( $27 \%$ dos professores) responderam afirmativamente à questão sobre a visita a homepage. Da mesma forma, os 18 professores (41\%) que nunca visitaram uma homepage, também não trocaram nenhuma mensagem via e-mail. O restante, da ordem de $30 \%$ dos professores, já haviam visitado alguma homepage, mas não tinham utilizado e-mail para comunicação.

Em relação às questões 9,10 e 11, que também perguntam sobre a utilização de outras ferramentas da Internet como "lista de discussão, new groups ou Chat", o quadro de respostas mostra a ínfima porcentagem de professores que utiliza essas ferramentas de comunicação.

\begin{tabular}{|c|c|c|c|}
\hline Respostas & $\begin{array}{c}\text { Você participou de } \\
\text { lista de discussão }\end{array}$ & $\begin{array}{c}\text { Você participou de } \\
\text { new groups }\end{array}$ & $\begin{array}{c}\text { Você participou de } \\
\text { algum CHAT }\end{array}$ \\
\hline SIM & 3 & 0 & 5 \\
\hline
\end{tabular}

De um modo geral, podemos dizer que, dos professores de Física que participaram dessa pesquisa, menos de $10 \%$ conhecem e utilizam o computador de forma ampla; cerca de $25 \%$ dos professores utilizam apenas as ferramentas básicas de um computador; e ainda, da ordem de $40 \%$ desconhecem o uso do computador. Esse resultado é bastante surpreendente, pois, por lecionarem disciplinas da área de ciências exatas, esperava-se uma maior porcentagem de professores com conhecimento razoável de computador. 
Alguns exemplos de respostas mostram que são, fundamentalmente, duas as razões para esse pouco uso do computador:

- Não sabe operar:

"Não (visitou alguma homepage), necessito aprender a usar o computador" - "Não (trocou mensagens via e-mail), não sei usar um computador" (SP6).

“Não(não sei operar) (SP11).

- Condições financeiras:

“Não, não sei e não tenho computador [(preço) e (tempo)]. (SP11)

“..., não utilizo ainda devido a fatores financeiros.” (SP 21)

“Não, pelo poder de não ter condições financeiros, conheço pelos anúncios de TV.” (SP34)

Esses exemplos parecem indicar que, para o professor, a condição financeira é a principal razão que impede o uso do computador.

\section{I.1 ESPAÇO DA INFORMÁTICA}

Essa parte da pesquisa analisará as justificativas, considerações ou comentários dos professores sobre o computador e/ou Internet, a fim de extrair deles elementos ou indícios que possibilitem delinear melhor sua opinião sobre o computador.

Primeiramente serão analisados os elementos que os professores consideraram relevantes na caracterização da informática, em particular sobre o computador e a Internet e, posteriormente, serão analisados os elementos por eles considerados importantes na relação computador e escola.

As respostas apresentadas pelos professores foram bastante diversificadas, tanto em extensão quanto em relação à natureza de seus conteúdos expressos. Por isso, para essa análise, será utilizada a metodologia de análise de conteúdo. Essa metodologia exige uma leitura exaustiva das respostas, analisadas como um todo, de forma a identificar os 
indícios, elementos ou características, que, nas respostas dos professores, comparecem como relevantes. Os diferentes elementos darão origem às categorias de respostas ou tipos de respostas. A articulação desses diferentes tipos de respostas permitirá inferir uma visão dos professores sobre o computador.

\section{I.1.1 - Sobre o computador}

De um modo geral as respostas dos professores são bastante curtas e fragmentadas. A pobreza de elementos para análise não permitiu resultados abrangentes e profundos, como era desejado. Entretanto, a análise apresentou algumas importantes características dos professores de Física da rede pública de ensino da cidade de São Paulo.

Duas dimensões de análise foram escolhidas: âmbito de importância do computador, que engloba as respostas que contêm elementos indicativos do espaço em que ele é concebido, e potencialidades, que trata das respostas que dizem respeito às funções positivas do computador.

\section{A - Âmbito de importância}

Em relação à importância do computador, os professores consideraram-no imprescindível no uso diário e em todas as áreas de atividades. Exemplos de respostas que evidenciam essa importância são apresentadas abaixo.

\section{Essencial para todas as atividades}

"Que sem ele hoje a vida das pessoas param." (SP30)

"Um equipamento essencial no nosso dia-a-dia, e o homem está cada vez mais dependente dele" (SP27)

“... está se tornando cada vez mais necessário para o uso diário, tornando cada vez mais imprescindível o seu uso." (SP6)

“... tornou-se essencial o seu uso no nosso dia-a-dia, em todas as áreas de atividades." (SP 15)

"Ferramenta necessária para qualquer profissional, nos dias de hoje." (SP23) 


\section{B - Potencialidade do computador}

$\mathrm{Na}$ visão desses professores, o computador é um meio que veio para facilitar ou auxiliar as pessoas na execução de suas tarefas. Os exemplos de respostas são do tipo:

"É o meio mais fácil de resolvermos muitos trabalhos de nosso dia-adia."(SP3)

"Um instrumento facilitador e organizador de atividades do cotidiano de uma empresa ou nos afazeres de casa ou da escola" (SP8)

"Um pacote muito grande de ferramentas, que facilitam as atividades do homem." (SP 20)

"O computador é um meio de ajudar a humanidade tanto no nível intelectual. Como social." (SP21)

“..., que serve para otimizar tempo de execução de trabalho" (SP44)

Esses dois grupos de respostas indicam que, para os professores, o computador é um equipamento essencial para todas as áreas e que a sua função é auxiliar, no sentido de facilitar, a realização de atividades.

\section{I.1.2- Sobre a Internet}

Em relação à Internet foram identificadas quatro categorias de respostas: o alcance espacial, a rapidez na comunicação, a interatividade pessoal e fonte de informação.

\section{A - Alcance no espaço}

Nesse grupo estão as respostas que indicam abrangência espacial da Internet. São respostas do tipo:

"O mundo (acesso aos mais variados tipos de informações) interligados por computadores" (SP8)

"Sim, pois de dentro de casa pode-se viajar pelo mundo. Acredito." (SP30)

"Globalização e intercâmbio entre pessoas, cidades, estados, paises." (SP34) 
"Sim. Porque através dela (Internet) você comunica com várias pessoas em qualquer lugar do mundo." (SP35)

"Internet simboliza o contato ilimitado com o mundo todo, sem restrições e um rol de possibilidades"- "...possibilidade de estar em qualquer lugar do mundo"(SP44)

\section{B- Rapidez na comunicação}

Uma outra característica da Internet, identificada pelos professores, é a rapidez com que a comunicação é realizada. Alguns exemplos desse tipo de respostas são:

"Que você pode chegar a qualquer lugar, saber sobre qualquer coisa sem sair de casa e em pouco tempo." (SP3)

"A Internet fornece informações rápidas e nos proporcionam uma pesquisa ampla e selecionada" (SP8)

"Uma ligação com o mundo e suas diferentes culturas - uma enciclopédia em tempo real." SP17

"Pelo fato de podermos nos comunicar com pessoas de qualquer lugar do mundo de maneira rápida." (SP37)

"Economia de tempo." (SP40)

\section{C- Interatividade pessoal}

Um outro aspecto identificado como importante na Internet é a possibilidade de propiciar interação entre pessoas, de diferentes pontos, de vários países, como indicam alguns exemplos de respostas apresentados abaixo.

"Avanço tecnológico. Comunicação. Contato humano." (SP10)

"Um poderoso meio de comunicação entre os homens de diferentes paises." (SP20)

"Você tem a possibilidade de falar e ver a pessoa ao mesmo tempo." (SP27) 
"Globalização e intercâmbio entre pessoas, cidades, estados, paises." (SP34)

"Sim. Porque através dela (Internet) você comunica com várias pessoas em qualquer lugar do mundo." (SP35)

\section{D- Fonte de informação/grande}

Finalmente, o quarto tipo de respostas reconhece a Internet como enorme fonte de conhecimento. Exemplos desse tipo de respostas são:

"Que você pode chegar a qualquer lugar, saber sobre qualquer coisa sem sair de casa e em pouco tempo." (SP3)

"Realmente o que parece a Internet é uma grande biblioteca, lá se encontra de tudo." (SP9)

"Uma ligação com o mundo e suas diferentes culturas - $\underline{\text { uma }}$ enciclopédia em tempo real." (SP17)

"Diversão, aprendizado, conhecer novas culturas, babaquices, afinal tem tudo que se possa imaginar" (SP28)

"Creio que tudo o que se procura na Internet relacionado à informação deve-se encontrar..." (SP40)

Para os professores, a Internet é uma fonte de conhecimento quase infinita, que permite comunicação e interação de forma muito rápida e em escala mundial.

\section{I.2 - O COMPUTADOR NA ESCOLA}

Foram muito raras as respostas que tratavam do computador ou da Internet na educação, embora a questão 8 perguntasse explicitamente se 0 professor indicaria o uso da Internet para os alunos ou colegas. Dos 18 professores que afirmaram utilizar e-mail como meio de comunicação, apenas um não recomenda o seu uso por parte dos alunos. Nas justificativas só aparecem elementos que já foram identificados na análise da Internet, como a interação entre número maior de pessoas, a rapidez na comunicação e a Internet como fonte de informação. 
Alguns exemplos de respostas:

"Sim, recomendaria, pois é um meio rápido de enviar idéias. Seriam úteis por possibilitar a discussão de um assunto com um número maior de pessoas." (SP26)

"Sim, pois isto irá colocar os alunos, professores e colegas, mais próximos, em qualquer hora podemos trocar e-mail." (SP14)

"Sim recomendaria aos alunos e colegas, pois é uma maneira rápida de aquisição de dados, mas sem perder o contato direto entre eles. (SP 10)

"Já troquei sim, troco e vejo que poderia ser trabalhado sim com alunos." (SP7

"Desde que seja usada corretamente se torna uma ferramenta importante, pois não tem como virar as costas $p / 0$ avanço tecnológico. $O$ professor precisa adaptar-se a ela e tirar o máximo de proveito pois jamais o professor será substituído." (SP28)

Essa dimensão, computador na escola, foi definida pelo desejo de se obter elementos que permitissem identificar a relação do professor com o uso do computador na educação. Entretanto, além do questionário utilizado não apresentar questões que abordassem esse tema diretamente, a hipótese que havíamos feito de que apareceriam elementos dessa natureza em perguntas abertas e nas justificativas, não foi verificada. (Essa hipótese foi verificada com o segundo grupo de professores, e será apresentada na etapa II da análise).

\section{Etapa II - A informática no espaço do professor}

Essa segunda etapa da pesquisa vem complementar e ampliar o conhecimento sobre as diferentes relações que os professores de Física do ensino médio estabelecem com o computador, especificamente no espaço da atividade de ensino e de aprendizagem.

Em função dos resultados encontrados na Etapa I da pesquisa, que mostra o desconhecimento, por parte do professor, de várias das ferramentas relativas ao uso do computador como a Internet, homepage, new groups etc., e também, pela falta de elementos para compreender 
melhor a visão do professor sobre o papel do computador na educação e na sala de aula. Foi realizada essa segunda etapa da pesquisa, com 0 instrumento de tomada de dados modificado e aplicado em um outro grupo de professores.

A tomada de dados foi centrada novamente num questionário estruturado, sendo aplicado a cinqüenta (50) professores de Física da rede pública do Estado do Acre, que participavam de um curso de formação continuada, ministrado pelo GREF. Os professores pertencem à faixa etária entre 32 e 45 anos, e lecionam Física há mais de 5 anos, sendo que apenas três lecionam somente há 2 anos. Mesmo lecionando a disciplina Física no ensino médio, esses professores possuem formações acadêmicas bastante diversificadas, como licenciaturas em Química, Biologia, Física, predominando o número de professores com formação em Engenharia.

\section{Características do novo instrumento de tomada de dados}

O novo instrumento foi elaborado com alterações sobre 0 questionário utilizado na Parte $\mathrm{I}$, tornando algumas questões mais específicas com respeito à utilização do computador na educação. Esse novo questionário foi composto por 14 perguntas (Anexo 3.I.2).

Com o primeiro grupo de perguntas (questões 1, 4 e 6 do questionário) buscava-se respostas relacionadas ao uso e conhecimento pessoal do professor sobre os microcomputadores. Perguntava-se, simplesmente, se ele usava ou não regularmente os microcomputadores e a Internet, tentando assim buscar, em caso afirmativo, qualificar essa utilização, identificando a freqüência e os usos que ele fazia, ou mesmo programas e jogos eventualmente conhecidos.

$$
\text { Q1- Você já usou microcomputador? () Sim ( ) Não }
$$

Se sim, onde você utilizou? Qual é a freqüência de utilização?

Q4- Você conhece ou já ouviu falar de alguns programas utilizados nos microcomputadores? Quais ?(De alguns exemplos)

Q6- Você já usou ou usa a Internet? () Sim () Não

Se sim, com que freqüência? ( ) algumas vezes/semana ( ) algumas vezes/mês ( ) regularmente 
Questões sobre o computador e a Internet foram feitas de uma forma bem aberta, supondo que mesmo que fossem coisas distantes de sua realidade, permitiria que o professor dissesse algo a respeito daquilo que conhecia sobre as novas tecnologias. Pelo caráter aberto das questões, eram esperadas respostas que fizessem referência ao significado do computador na sociedade, à potencialidade da Internet como meio de comunicação entre pessoas e de serviços, e também, às situações envolvendo a educação. Nesse segundo grupo de perguntas, estão as questões 2, 5 e 11 do questionário.

Q2- O que você acha do computador?

Q5- O que vêm à sua cabeça quando se fala em Internet?

Q11- Como você acha que os professores se vêem e pensam diante dessas novas tecnologias?

O terceiro grupo de questões constituiu o núcleo principal dessa etapa da pesquisa, onde são apresentadas questões em torno da importância do microcomputador na vida do professor, na prática docente. Com as perguntas desse bloco (questões 3,7 e 9), buscava-se compreender que limitações e potencialidades os professores reconhecem nas possíveis conquistas da informática, seja atualmente, seja em relação à evolução do microcomputador, e qual a sua opinião em relação à aplicação em sua prática pedagógica. São elas:

Q3- Você gostaria que o microcomputador fosse mais utilizado nas escolas?
( ) $\operatorname{Sim}$
( ) Não De que maneira ?

Q7-Você acha que, no futuro, será possível aprender tudo com um microcomputador e não mais participar das atividades presenciais nas escolas?

Q9-Pensando no que a escola ensina, como você acha que o microcomputador poderia ser um agente/recurso facilitador no processo de ensino?

Resumindo, portanto, essas questões centrais buscavam investigar o quanto o microcomputador pode ser útil para o professor, seja 
relacionando ao seu dia-a-dia na sala de aula ou em sua vida e procurou saber quais suas limitações e potencialidades.

Com o quarto grupo de questões (questões 10, 12 e 13), procurouse investigar como vêm sendo implementados esses computadores nas escolas (programas governamentais) e quais as relações e observações que o professor tem a respeito desses projetos.

Q10- Para você, uma escola ideal, necessariamente, precisa de microcomputador?

Sim（ ) Não( ) Se sim, qual o número ideal para a sua escola?
( ) somente um
( ) de 2 ate 10
( ) de 10 até 20
( ) 20 ou mais

Qual seria o motivo dessa quantidade?

Q12- Sua escola já recebeu computadores do governo / secretaria?

Sim ( ) Não ( ) Se sim, como estão sendo utilizados esses microcomputadores em sua escola? Você concorda?

Q13- O que você mais preferiria ter em sua escola

( )Laboratório de microcomputadores ( ) Laboratório de Recursos audiovisuais ( ) Laboratório didático ( ) Biblioteca; ( ) Outros:

\section{Por quê?}

$E$, finalmente, no quinto grupo de questões (questões 8 e 14) estão as perguntas que procuravam evidenciar reflexões dos professores sobre a questão das novas tecnologias. Uma delas (Q14) é a mesma aplicada na Etapa I da pesquisa.

Q8-Como você acha que a Ciência está relacionada com essas novas tecnologias?

Q14- Comente a frase abaixo:

"As novas tecnologias, ao mesmo tempo em que permitem um avanço significativo das comunicações entre os homens, simultaneamente os aliena."

Também havia um espaço livre para manifestações do professor, seja sobre a forma como gostaria de conhecer a informática, seja dando sugestões ou fazendo comentários gerais. 


\section{Análise das respostas}

Utilizando o mesmo critério da Etapa I, as respostas dos professores serão analisadas segundo duas dimensões que se complementam: a primeira se refere ao espaço da informática concebido pelo professor, e a segunda, mais específica, é relativa à visão do professor sobre a informática na educação.

Na primeira dimensão (espaço da informática), serão analisadas as respostas dos grupos de questões 1 e 2, e, na segunda dimensão (informática na educação), serão analisadas as respostas dos grupos 3 e 4 , caracterizados na apresentação deste instrumento de coleta de dados. As respostas relativas às questões do grupo 5 , pelo fato de estarem além do recorte de análise, não farão parte dessa pesquisa.

\section{1 - ESPAÇO DA INFORMÁTICA}

As análises serão apresentadas segundo os diferentes grupos de questões. Em cada um desses grupos, inicialmente, as respostas diretas foram tabuladas, de forma a fornecer uma visão global. Em seguida, serão analisadas as justificativas e as considerações utilizadas pelos professores com o intuito de compreender as principais idéias nelas contidas, ou seja, os indícios ou os elementos que nos permitirão elaborar a visão do professor sobre o tema.

\section{II.1.1 - Grupo de questões -1}

No primeiro grupo, desejava-se conhecer qual a familiaridade do professor com os microcomputadores. O resultado é mostrado a seguir.

Se os professores usam/usaram microcomputadores

SIM: 43 (86\%) NÃO: $6(12 \%) \quad$ NÃO RESPONDEU: 1 $(2 \%)$

As tabelas 1 e 2 (abaixo) mostram onde, e com que freqüência, o professor usava o microcomputador, com uma comparação percentual do 
valor obtido em relação ao número total de professores (43 professores) que usam ou já utilizaram o computador.

Tabela 1 - Onde os professores usam/usaram os microcomputadores

\begin{tabular}{|c|c|c|}
\hline & Número de respostas & Porcentagem \\
\hline No trabalho & 13 & 30 \\
\hline Em casa & 15 & 35 \\
\hline Na escola & 8 & 19 \\
\hline Em outros lugares & 8 & 19 \\
\hline
\end{tabular}

Tabela 2 - Freqüência com que os professores usam os microcomputadores

\begin{tabular}{|c|c|c|}
\hline & Número de respostas & Porcentagem \\
\hline Constantemente & 29 & 67 \\
\hline Raramente & 10 & 23 \\
\hline Não citou & 4 & 9 \\
\hline
\end{tabular}

Existem respostas em que um mesmo professor indica que utiliza o computador em sua casa e no trabalho, sendo a sua resposta, nesse caso, computada tanto fazendo parte do grupo que o utiliza no trabalho, e também, em casa. Alguns exemplos de cada grupo de respostas da Tabela 1:

Utiliza no trabalho:

"Sou técnico de informática; sempre utilizo." (A6)

"Num antigo trabalho (local). Todos os dias. Agora a freqüência é muito raramente." (A30)

"No meu local de trabalho (Banco). Diariamente." (B3)

\section{Em casa}

"Em casa, diariamente." (B4)

"Utilizo na minha casa, com freqüência boa. Não uso diariamente, mas sempre que posso e necessito." (B6)

"Na escola e na minha casa. Duas a três vezes por semana." (A3)

$\underline{\text { Na escola }}$

"Sim, na escola. Diária." (A8) 
"Na escola e na minha casa. Duas a três vezes por semana." (A3)

"Em minha residência e na escola em que trabalho, em média duas a quatro vezes no mês." (B2)

\section{Em outros lugares}

"Em cursos, casa de parentes e amigos. Uma vez por semana."(A21)

"Na universidade: 2 horas $x$ dia." (A20)

"NTE-Núcleo de Tecnologia Educacional - Rio Branco - Acre. Pesquisa." (A38)

Esses primeiros dados, principalmente aqueles que nos informam que cerca de $90 \%$ dos professores usam ou já usaram microcomputadores, e ainda, $67 \%$ deles utilizam constantemente (Tabela 2), já indicam que os professores desse grupo são bastante diferentes daqueles que participaram da Etapa I da pesquisa.

Nota-se, na tabela 1, que cerca de um terço dos professores que responderam o questionário usam os microcomputadores no trabalho, que não é a escola e sim uma segunda atividade. Mas já é significativo o número de professores que já utilizam computadores na/da escola (cerca de $20 \%$ ).

Conhecido o número de professores que conhecem ou não programas utilizados no microcomputador, a tabela 3 mostra quais seriam esses programas.

\begin{tabular}{|c|c|c|}
\hline \multicolumn{3}{|c|}{ O professor conhece ou não programas utilizados no microcomputador } \\
\hline SIM: $40(80 \%)$ & NÃO: $10(20$ & \\
\hline \multicolumn{3}{|c|}{ Tabela 3 - Programas conhecidos pelo professor } \\
\hline & Número de respostas & Porcentagem \\
\hline Apenas pacote Microsoft Office & 26 & 56 \\
\hline Pacote Microsoft + outros programas & 6 & 9 \\
\hline Softwares Educacionais & 10 & 20 \\
\hline Outros & 8 & 15 \\
\hline
\end{tabular}


Existem professores que não distinguem programas específicos (pacote Office) de sistemas operacionais (Windows, DOS, LINUX), dizendo muitas vezes utilizar o Windows para produzir um texto ou uma planilha eletrônica. Existe uma parte dos professores que reconhecem outros programas quando trabalha com imagens e sons (Corel e Arcview).

Exemplos de respostas à pergunta sobre programas de computador:

\section{Pacote Microsoft}

"Sim. Windows, Word, Excell, Power Point, Print, Lotus etc." (J1)

"Sim, Windows, Word, Power Point ..." (B6)

"Word - texto etc. Excel-gráfico," (A38)

Pacote Microsoft + outros programas

"Sim, Office, Dos, Windows ..." ( A7)

"Sim. Word, Corel Draw, Phot-paint, Arc-view etc." (A26)

"Sim, Windows, Power Point, Page Make e outros." (A13)

"Sim. Power Point, Excel, Internet Explorer, Publisher, Word ..." (M1)

"Além dos programas usuais dos micros (windows, Office e Corel), tenho utilizado em experiências alguns jogos de games e pequenos programas de coleta e análise de informação." (A29)

Softwares educacionais

"Sim. Algumas de Física, Química; Micromundos, Super Interessante." (A6)

"Sim, Fuvest; Univest; Positivo etc. (A19)

OUTROS TIPOS DE RESPOSTAS

"Vários, utilizo muitos deles, desde um simples editor de texto a linguagens complexas de programação." (A2) 
"Programei em Assembler, mas já faz muito tempo." (A16)

"Ambientes CMS e banco de dados." (A23)

Pelos dados, nota-se que a maioria dos professores $(80 \%)$ conhecem os programas utilizados no microcomputador e que cerca de metade deles tem conhecimento do que é o pacote Microsoft, que possui ferramentas básicas de edição de textos e formulação de planilhas. Em relação aos programas de educação, apenas um professor faz referência a software "educacional" e um outro cita "site" de vestibulares.

É diferente também dos resultados da Etapa I, a utilização ou não da Internet pelos professores, pois cerca de $70 \%$ afirmam usar ou já ter utilizado a Internet.

Professores que usam/usaram a Internet
SIM: $34(68 \%)$
NÃO: $16(32 \%)$

A freqüência dessa utilização é apresentada na tabela 4.

Tabela 4 - Freqüência de utilização da Internet

\begin{tabular}{|c|c|c|}
\hline & Número de respostas & Porcentagem \\
\hline Regularmente & 9 & 18 \\
\hline Algumas vezes/semana & 11 & 22 \\
\hline Algumas vezes/mês & 14 & 28 \\
\hline Não utiliza & 16 & 32 \\
\hline
\end{tabular}

Considerando que não existe diferença significativa entre aqueles que acessam a rede regularmente e aqueles que a utilizam algumas vezes por semana, pode-se inferir que $40 \%$ dos professores utilizam a Internet em suas atividades.

A relação do professor com o computador, em termos de sua utilização, é resumida na Tabela 5.

Tabela 5 - Utilização da Internet e conhecimento de programas

\begin{tabular}{|c|c|c|}
\hline Relação & $\begin{array}{c}\mathrm{N}^{\circ} \text { de } \\
\text { professores }\end{array}$ & $\begin{array}{c}\text { Indicação por } \\
\text { "cor" }\end{array}$ \\
\hline Usa Internet regularmente e conhece programas & 7 & azul \\
\hline $\begin{array}{c}\text { Usa Internet algumas vezes /semana e conhece } \\
\text { programas }\end{array}$ & 10 & verde \\
\hline \multicolumn{2}{|c|}{} & \\
\hline
\end{tabular}




\begin{tabular}{|c|c|c|}
\hline $\begin{array}{c}\text { Usa Internet algumas vezes/mês e conhece } \\
\text { programas }\end{array}$ & 10 & amarela \\
\hline $\begin{array}{c}\text { Usa Internet regular./semanal e não conhece } \\
\text { programas }\end{array}$ & 3 & laranja \\
\hline Não usa Internet e conhece programas & 7 & magenta \\
\hline $\begin{array}{c}\text { Usa Internet algumas vezes/mês e não conhece } \\
\text { programas }\end{array}$ & 4 & roxa \\
\hline Não usa Internet e não conhece programas & 9 & vermelha \\
\hline
\end{tabular}

A partir do próximo item dessa análise, os exemplos que caracterizam as respostas serão indicados com as cores referenciadas na tabela (5) acima. Por exemplo, se após o exemplo, a identificação estiver em cor azul, significa que a frase é de um professor que utiliza Internet regularmente e conhece programas de computador.

\section{1.2 - Grupo de questões 2}

Nesse grupo estão as questões que foram apresentadas de forma bastante aberta, de modo a possibilitar a obtenção de informações sobre os elementos que os professores consideram relevantes, em relação ao computador e a Internet, e, assim, traçar algumas visões dos professores sobre o uso da informática.

A análise das respostas desse grupo de questões seguirá a mesma metodologia de análise de conteúdo, utilizada na Etapa I, que consiste em identificar nas respostas indícios que caracterizam diferentes modos de pensar e formular tipos ou categorias de respostas representativas da amostra em análise.

\section{II.1.2.1 - Sobre o computador}

Após leituras exaustivas e várias tentativas de se estabelecer critérios de análise que evidenciassem a natureza e as características dos diferentes tipos de respostas, duas dimensões de análise foram definidas: $\underline{0}$ âmbito em que o computador é identificado preferencialmente pelo professor e as suas potencialidades. 


\section{1- Âmbito de importância do computador}

Foi possível identificar um grupo de respostas que colocam/localizam o computador num âmbito bastante geral, indicando o espaço por ele ocupado na sociedade moderna. Um outro grupo de respostas o localiza num âmbito mais restrito, em particular, na educação. Exemplos de respostas que evidenciam esses dois âmbitos são apresentados abaixo. Outros exemplos podem ser encontrados no Anexo 3.II.1.

\section{A - Sociedade}

"Acho um grande progresso em tecnologia, uma máquina com uma importância para todos os ramos e que facilita nossos trabalhos e nossa vida." ( $\mathrm{B} 6)$

"A utilização é infinita, não tenho a menor dúvida. No mundo globalizado em que nos encontramos é simplesmente indispensável." (A18)

"É muito importante para todos, pois é um recurso que usamos para nos atermos do que nos cerca..." ( A12)

"Acho que é um aparelho de muita importância para o século que estamos vivenciando."

\section{B - Educação}

"Uma ferramenta de extrema necessidade nos dias atuais para 0 professor como um recurso que possibilita aproximar o aluno da realidade diante de assuntos complexos."

"Uma ferramenta poderosa no auxílio da prática pedagógica." (A8)

"É um equipamento indispensável no ensino-aprendizagem." (A32) milênio" (A5)

"Uma ferramenta de extrema importância para a educação no novo

Através das cores das respostas é possível notar uma tendência dos professores que conhecem/utilizam computador focalizarem a sua importância num âmbito mais geral (respostas de cores azul e verde são mais freqüentes) e daqueles que não conhecem (roxo e vermelho) relevarem o âmbito da educação. Assim, os primeiros consideram 0 
computador um grande progresso em tecnologia e muito importante na compreensão da sociedade tecnológica atual; e os demais o identificam como uma ferramenta indispensável para a educação.

\section{2- As potencialidades do computador}

Uma outra dimensão de análise trata das potencialidades do computador, ou seja, a função e o sentido de seu uso. As respostas nessa dimensão relevam apenas os aspectos positivos, como um equipamento que propicia a melhora na qualidade das atividades, que as agiliza ou que facilita sua execução.

\section{A - Instrumento que melhora a qualidade}

Uma outra visão dos professores sobre o computador é aquela em que ele é concebido como um instrumento que melhora a qualidade, seja do trabalho, da vida ou até de lazer. Alguns exemplos:

"É uma máquina que proporciona a quem usa uma qualidade de trabalho bem avançado." ( A13)

"Um instrumento importantíssimo nos dias de hoje para aperfeiçoar no trabalho, comunicação, lazer, ...”

" É muito útil; contribui em muito para melhorar a vida das pessoas."

“... temos que implantá-lo na educação que com certeza ajudará o trabalho do professor como melhorar a qualidade de ensino. Pois, melhor é para o aluno entender." (A10)

"Um meio que torna quase tudo mais rápido e melhor, com possibilidade de comunicação e fazer trabalhos mais perfeitos." (A30)

As cores das respostas mostram uma leve tendência dos professores que não conhecem computador, atribuir a eles um potencial positivo, ou seja, eles estão presentes para "melhorar" a qualidade das atividades. 


\section{B - Instrumento que agiliza atividades}

Um outro potencial ou qualidade atribuído ao computador é a sua capacidade de agilizar ou facilitar as atividades, como mostram os exemplos de respostas abaixo.

“...é um meio simples e rápido de consulta através do qual pode-se obter informação sobres os mais variados assunto por meio de várias fontes de pesquisa." (A21)

"É útil para agilizar alguns trabalhos."

"Instrumento de simplificação de trabalho; dispositivo de redução de tempo." (A36)

"Um meio que torna quase tudo mais rápido e melhor, com possibilidade de comunicação e fazer trabalhos mais perfeitos." (A30)

Dessas respostas é possível observar que a rapidez é propiciada em vários tipos de atividades como a obtenção de informação, de comunicação ou de realização de tarefas.

\section{C - Instrumento que facilita tarefas}

Abaixo são apresentados alguns exemplos de resposta que mostram o computador com o seu potencial facilitador:

"Acho um grande progresso em tecnologia, uma máquina com uma importância para todos os ramos e que facilita nossos trabalhos e nossa vida." ( $\mathrm{B} 6$ )

"O computador foi uma das grandes invenções da humanidade e que a vida seria muito difícil sem ele." (A8)

"É uma máquina que facilita a elaboração dos trabalhos e ajuda também na compreensão dos alunos." (B5)

"Uma máquina fantástica que facilita na compilação de dados, cálculos e arquivos em empresas." (A4)

"... é um instrumento que existe para facilitar a vida no sentido de pesquisas, trabalho etc." ( B1)

O caráter facilitador do computador, apontado por este tipo de resposta, foi o mais freqüente nas respostas de professores (da ordem de 
$25 \%$ do total), principalmente daqueles que não conhecem o computador, como pôde ser evidenciado pelas cores das respostas.

Por outro lado, os professores que foram considerados como conhecedores de computador apontam, com maior freqüência, a característica do computador como fonte de pesquisa e de aquisição de conhecimento, conforme exemplos a seguir:

\section{D - Fonte de pesquisa e conhecimento}

"Uma ferramenta de maior importância para a comunicação e principalmente como forma de adquirir conhecimento." (A3)

“...é um meio simples e rápido de consulta através do qual pode-se obter informação sobres os mais variados assunto por meio de várias fontes de pesquisa." (A21)

"Que é uma fonte de informação e pesquisa." (A34)

"Excelente ferramenta de estudo, pesquisa, entretenimento, entre outros." (M2)

"Um bom instrumento pedagógico de pesquisa e conhecimento."

Todos os professores, de um modo geral, consideram o computador como uma ferramenta que melhora a qualidade dos trabalhos realizados, que facilita e agiliza as tarefas e, para aqueles que o conhecem e o utilizam, é fonte de pesquisa e obtenção de conhecimento.

Entretanto, analisando as respostas relativas à Internet, cerca de $30 \%$ dos professores, independente da utilização ou não do computador, reconhecem explicitamente que a Internet é uma fonte de pesquisa, informação e conhecimento.

\section{II.1.2.2 - Sobre a Internet}

Em relação à Internet, quatro grupos de respostas significativas explicitam algumas de suas características: fonte de pesquisa/conhecimento, alcance no espaço e rapidez na comunicação. 


\section{A - Fonte de pesquisa/conhecimento}

Como já mencionado, cerca de $30 \%$ dos professores consideram a Internet como fonte de pesquisa e de informação ou conhecimento. Exemplos de respostas que evidenciam essa característica são apresentadas abaixo. Outros exemplos podem ser encontrados no Anexo 3.II.2.

"O progresso, o acesso à várias informações, comodidade $e$ pesquisas." ( B6)

"Fonte de pesquisa, curiosidade, entretenimento, trocas de experiências, aquisição de conhecimento, trabalho." (A29)

"É uma rede mundial de comunicação, e é muito bom para pesquisas."

"Em uma rede para buscar conhecimentos e entrar em sintonia com o mundo da informação e ajuda a sair do comodismo, e atualizando ao mundo." (A10)

"Um mundo de informações e serviço disponível a uma grande massa populacional." (A5)

Além dos professores considerarem a Internet como fonte de informação, consideram-na também como um meio de comunicação de abrangência mundial, como exemplificam algumas respostas.

\section{B - Possibilita interação}

A seguir estão exemplos de respostas dos professores com relação à interatividade promovida pela Internet.

"Uma rede de interação de conhecimento, mas que ainda não dominados por todos." (A6)

"Fonte de pesquisa, curiosidade, entretenimento, trocas de experiências, aquisição de conhecimento, trabalho." ( A29)

"Um meio de comunicação e troca de informação mundial, de modo prático e rápido". (A21)

"Atualização dos conhecimentos. Tecnologia. Troca de conhecimentos." 
Percebe-se que os professores interpretam a Internet como um meio de interação que proporciona a troca de informações, e parece ser uma tendência dos professores que conhecem e utilizam esses meios.

\section{C - Alcance no espaço}

A seguir estão exemplos de respostas dos professores diante do que consideram ser o alcance da Internet.

“Ligação com o mundo. Informações acessíveis. Facilidade.” (A26)

"Um meio de comunicação e troca de informação mundial, de modo prático e rápido". (A21) pesquisas."

"É uma rede mundial de comunicação, e é muito bom para

"Estar em contato (conectado) com o mundo, sair do isolamento físico, intelectual ... estar atualizado...” ( B7)

"O mundo em minhas mãos, didaticamente e culturalmente falando.

Aproximadamente $30 \%$ dos professores citam, em suas respostas, esse aspecto da Internet de possibilitar uma comunicação mundial, concebendo assim um espaço mundial reduzido pelo computador ("mundo em minhas mãos").

\section{D - Rapidez na comunicação}

Como conseqüência da diminuição do espaço, temos a rapidez na comunicação. Essa característica da Internet é citada por apenas 10\% dos professores. Alguns exemplos:

"Um meio de comunicação e troca de informação mundial, de modo prático e rápido". (A21)

"Uma rede internacional de informações, com uma facilidade que outro meio de comunicação não possui para se acessar informações $\underline{\text { com }}$ uma velocidade incrível".

"Internet é a maneira mais rápida de se buscar informações a qualquer distância que estejamos em tempo real."

"É a maneira mais rápida de comunicar." (A28) 
"Transmissão e recepção de informações com maior freqüência e rapidez." (A27)

Em síntese, para os professores, a Internet é um sistema de comunicação mundial muito rápido, através do qual é também possível obter informações e conhecimento.

\section{II.1.2.3 - Sobre a visão do professor diante das novas tecnologias}

Algumas das respostas apresentadas à questão sobre como os professores se colocavam frente às novas tecnologias, vêm reforçar a visão positiva do uso do computador, seja ele auxiliando a aquisição de conhecimentos ou facilitando a prática do professor. São exemplos de respostas as frases apresentadas abaixo. Outros exemplos podem ser encontrados no Anexo 3.II.3.

\section{A - Função positiva}

"No meu ponto de vista as tecnologias ajudam ao professor ter uma melhor qualidade de ensino." (A13)

"Os professores vêem essa tecnologias como uma nova ferramenta muito útil para facilitar seu trabalho." (A3)

"Com novas fontes e possibilidades de adquirir e renovar os conhecimentos."

"Os professores vêem essas tecnologias como uma aliada no processo ensino-aprendizagem." (B8)

"Muitos podem até pensar que podem ser substituídos, mas o computador é um instrumento que só veio a somar no seu trabalho." (A28)

Embora o computador seja apresentado como uma tecnologia que vem a favor do professor, um dado bastante significativo é o grande número de professores, cerca de $20 \%$ do total, que julga existir uma parcela deles que sente medo ou temor dessas novas tecnologias, e se encontram assustados ou ameaçados.

\section{B - Medo e temor}

Exemplos de respostas que expressam sentimentos de medo ou de apreensão são apresentados abaixo: 
"Há muitos que tem temor! Mas, muitos estão alterando seus programas de aulas, por perceberem que é necessário avançar com a mesma velocidade da tecnologia." (A26)

"Assustados. Pois os que não estão preparados, serão vencidos pelo tempo." (A19)

"A maioria dos colegas 'estão', ou tem medo dessas mudanças na tecnologia, pois caminha a passos largos..." (A2)

"Atônitos. A maioria não sabe usa-las de forma prática, aliás, não sabem usa-las de forma alguma." (A35)

"Com medo das novas tecnologias, porque não foram preparados para manusearam essas máquinas maravilhosas, ou seja, precisariam conhece-los para depois transmitirem as vantagens dessas novas tecnologias. " (A8)

Palavras contundentes como "medo", "temor" ou "assustados" aparecem em respostas de professores que foram classificados como aqueles que conhecem ou utilizam computadores. $O$ único professor que não é desse grupo (A8) é um dos que, de alguma forma, justifica o "medo" dessa nova tecnologia: não foram preparados para manuseá-la, ou seja, mostra que esse tipo de reação está associada ao desconhecimento.

É interessante observar que esses termos contundentes não partem da maioria das respostas de professores que pertencem ao grupo intermediário, ou seja, aqueles que conhecem o computador, mas não utilizam freqüentemente a Internet. Os termos utilizados são mais "suaves", como "apreensivos" ou "perdidos", conforme alguns exemplos abaixo:

\section{C - Apreensivos e perdidos}

"A grande maioria se vê perdido em um meio onde os alunos entendem melhor da máquina do que os mesmos."

"Apreensivos, pois muitos professores ainda não tiveram a oportunidade ou não interessaram em utilizar um computador."

"Muitos se sentem perdidos sem saber o que fazer. Outros querem utilizar essas novas tecnologias mas não sabem como agir." (B7)

"Obsoletos e defasados." (A36) 
"Perdidos, por falta de recursos e estudos para uma boa utilização dessas tecnologias." (B3)

Os exemplos de respostas acima indicam que algumas das razões dessas apreensões estão no desconhecimento do próprio objeto e de seu uso. Essa análise é confirmada se olharmos para as respostas dos professores classificados como não conhecedores de computador:

\section{D - Sem domínio do objeto}

"Alguns que são conhecedores pensam em uma nova visão para o ensino. Os que são menos conhecidos ainda não tem uma visão de como associar ao ensino as novas tecnologias." (B5)

"Os que ainda não dominam a tecnologia se sentem pressionados para dominar o mais rapidamente possível a nova tecnologia." (A4)

"Num mar cheio de conhecimento e será que estamos preparados para essa tecnologia? Como se preparar?" (B9)

"Alguns, impossibilitados de usa-lo, ou por ainda não saber, ou porque não dispõe do equipamento." (A30)

"Preocupante, pois nem todos têm recursos de estar usando essas novas tecnologias." (A31)

Os exemplos de respostas apresentados indicam, de alguma maneira, que a grande maioria dos professores que não utiliza computador está bastante perdida, sente-se pressionada, não sabe como utilizar essas novas tecnologias e nem como se preparar para o seu uso na educação.

\section{II.2 - INFORMÁTICA NA EDUCAÇÃO}

Para a análise das respostas nessa dimensão, serão utilizadas principalmente respostas dos $3^{\circ}$ e $4^{\circ}$ grupos de questões, que dizem respeito diretamente ao computador na educação. Entretanto, em várias respostas às outras questões aparecem menções sobre alguma relação entre educação e informática. Assim, para essa parte da análise serão utilizadas também respostas que tratam da informática na educação, independentemente a qual questão a resposta é dirigida. 
Observa-se que a totalidade dos professores considera 0 microcomputador um instrumento importante na educação e, principalmente, no processo ensino-aprendizagem.

Vinte por cento (20\%) dos professores citam a importância do computador, mencionando-o como um instrumento de suporte pedagógico para complementar as aulas, incentivar os alunos, tornar as aulas mais dinâmicas, preparar o trabalho do professor, entre outras finalidades, sem, no entanto, explicitar a natureza de cada uma dessas ações. Exemplos de respostas dessa natureza são do tipo:

"Claro, os computadores têm ajudado a facilitar o ensino em várias escolas." (A2)

"[O computador] Importante recurso para aligeirar entendimento do processo ensino-aprendizagem."

"[O computador] Uma ferramenta poderosa no auxílio da prática pedagógica." (A8)

"[O computador] É um equipamento indispensável no ensinoaprendizagem." (A32)

"[O computador] Uma ferramenta de extrema importância para a educação no novo milênio" (A5)

Através dos exemplos apresentados, é possível observar que ocorre uma tendência significativa de os professores que não conhecem/utilizam computadores, utilizarem termos como "ferramenta poderosa", "indispensável”, "imprescindível”, "de extrema importância”; e isso parece indicar uma maior crença desses professores no alcance do uso positivo desse equipamento. Já os professores que conhecem/utilizam computador, utilizam em suas respostas termos como "suporte", "complementar", "facilitar", "aligeirar", que parece indicar uma visão do computador mais como um apoio pedagógico.

Outras respostas fornecem elementos favorecendo a compreensão das funções que os professores atribuem ao computador. Cerca de $25 \%$ dos professores identificam o computador como um instrumento de auxílio em sua função profissional; aproximadamente $50 \%$ deles, independente de sua 
relação com o uso/conhecimento do equipamento, reconhecem-no como um meio de pesquisa; da ordem de $70 \%$ dos professores se referem ao computador como um mediador de sua prática em sala de aula. E, ainda, cerca de $15 \%$ dos professores apontam seu uso, não como meio, mas como objeto de aprendizagem.

Para cada um dos tipos de respostas caracterizadas acima, serão apresentados alguns exemplos. Mais exemplos podem ser encontrados no Anexo 3.II.4. O primeiro grupo de respostas será indicado por preparo do professor, o segundo por meio de pesquisa, o terceiro por ensinoaprendizagem e, o último, por objeto de aprendizagem.

\section{1- Preparo do professor}

"O computador facilita em tudo, por exemplo, elaboração de exercícios, apostilas, similares, pesquisa na Internet etc. $O$ uso de alguns programas em áreas específicas, também facilita o processo de ensino; $C D$ ron é um outro recurso muito importante. " (A3)

" Com um micro ligado à Internet, você pode acessar bibliotecas, pode conversar com professores do mundo inteiro e com isso facilitar o ensino." (A35)

"Elaborar provas, alunos digitarem seus trabalho e se possível para ajudar como um recurso audio-visual nas aulas com o uso de datashow."

"Para pesquisa, para elaboração de projetos, desenhar, etc." (A8)

"Como fonte de pesquisa e na construção de experiências ou programas." (A30)

Dos exemplos de respostas acima, é interessante observar que a natureza do uso do computador parece ser diferente entre os professores: para aqueles que o conhecem/usam, ele pode ser utilizado para elaborar provas ou textos, acessar bibliotecas e até conversar com professores do mundo inteiro; e, para aqueles que não o conhecem/utilizam, ele não aparece como um instrumento de elaboração de provas, mas pode ser utilizado na elaboração de projetos, construção de experiências ou programas, rever teorias ou fazer planejamento escolar utilizando outros existentes. Para esse último grupo, a visão do papel do computador nas 
atividades de preparo do professor parece ser bem mais ampla e talvez irreal.

\section{2- Meio de pesquisa}

O papel mais importante atribuído ao computador, ou seja, a característica que com maior freqüência compareceu nas respostas dos professores, se refere a ele como fonte de pesquisa:

"[Internet] Um dos meios mais utilizado por alunos e professores como fonte de pergunta" (A1)

"Com um micro ligado à Internet, você pode acessar bibliotecas, pode conversar com professores do mundo inteiro e com isso facilitar o ensino." (A35)

"Para pesquisa dos alunos. Se ligar a Internet. Interação dos alunos com a tecnologia atual."

"Que as escolas tivessem salas bem amplas para alocar microcomputadores em redes, para pesquisas dos alunos."

"O computador é muito útil, para as aulas práticas, porque os alunos iriam realizar várias atividades, como digitar textos, fazer pesquisa através da Internet." (A28)

"Em termo de fonte de pesquisa tanto para o aluno como para o educador e assim fortalece ainda mais a parte intelectual de todos (professores e alunos)" (B1)

Embora cerca de $50 \%$ dos professores tenham indicado 0 computador como um meio de pesquisa educacional, através dos exemplos de respostas apresentados acima é possível observar que apenas um identifica a natureza ou fonte da pesquisa: "pode acessar bibliotecas, pode conversar com professores do mundo inteiro..."

\section{3- ensino-aprendizagem}

No processo ensino-aprendizagem, o uso do computador foi identificado, como um instrumento que melhora a apresentação da aulas e como importante objeto que o aluno deveria conhecer (aprendesse sobre ele) e também utilizar (aprendesse como usá-lo). 


\section{3-1: ensino : melhorar a apresentação}

"Pode ser utilizado como fonte de pesquisa, como instrumento para demonstrações audiovisuais." (A1)

"Com certeza, pois é um meio mais atrativo e ilustrativo para esclarecer o que muitas vezes não pode ser feito com papel e caneta ou quadro negro e giz." (A21)

"Para pesquisa na Internet, aulas com aplicativos didáticos e aulas com uso de um datashow." (A35)

"Diminuir tempo na apresentação. Mostrar de maneira clara $e$ precisa algo que se está ensinando." (B3)

"O computador facilita visualização da teoria, ou seja, é possível com o computador mostrar a teoria como ocorre na prática." (A8)

"Sim, através do micro facilita as explicações e conseqüentemente a aprendizagem." (A25)

Os exemplos de respostas apresentados mostram claramente que apenas os professores que utilizam/conhecem computador indicam a natureza do uso do computador na melhoria de apresentação de suas aulas. Também indicam, por exemplo, a utilização de datashow como recurso audiovisual, a utilização para visualizar situações complexas ou simplesmente apresentação visual de situações em que não são possíveis representações com ferramentais tradicionais, como quadro negro e giz.

Os professores que não conhecem/utilizam o computador apenas o citam, de forma vaga, como algo que "facilita a visualização da teoria" ("mostrar a teoria como ocorre na prática") ou que o computador "facilita as explicações".

\section{3-2: aprendizagem - utilização pelo aluno}

"Primeiro o aluno tem que aprender a utilizá-lo; em seguida usaríamos para construção de gráficos, fórmulas etc." (A13)

"Exemplos e resolução de questões com quit multimídia, ou via Internet." (A19)

" ....é possível usar aplicativos didáticos que simulam laboratórios de química, física etc. (A35)

"Com programas específicos em áreas disciplinas afins." (A36) 
"O computador é muito útil, para as aulas práticas, porque os alunos iriam realizar várias atividades, como digitar textos, fazer pesquisa através da Internet." (A28)

"Com laboratórios e programas mais específicos na área." (A17)

Quanto ao uso do computador por parte dos alunos, além das pesquisas que eles podem realizar através da Internet (analisada no item 2), os exemplos de respostas apresentadas indicam outras formas de utilização, como construção de gráficos e fórmulas, resolução de problemas, simulação de experiências e digitação de textos. Aqui também os professores que não utilizam/conhecem o computador indicam apenas o seu uso em digitação ou em utilização de programas específicos da área, de forma bastante vaga.

4- objeto de aprendizagem

"..... e colocaria o aluno em contato direto com a tecnologia e seus avanços." (B6)

"Não acredito que o estudante de hoje, possa entrar num mundo globalizado como o de hoje, possa ser um bom aluno sem a utilização do microcomputador." (A18)

"Sim, sem deixar que o computador se torne em vício somente pelo prazer de dizer que estamos utilizando computadores e sim pela necessidade que o mundo exige. "

"Para pesquisa dos alunos. Se ligar a Internet. Interação dos alunos com a tecnologia atual."

"Para que todos os alunos pudessem ter acesso e acompanhar de perto esses avanços." (A28)

"Que os alunos tivessem mais oportunidade de manuseá-lo, mais tempo de estudo do mesmo e com o mesmo, etc" (B1)

Esses exemplos de resposta mostram, de certa forma, um outro objetivo para o uso do computador na escola, não somente como meio de instrução, mas como um objeto que o aluno deve conhecer para responder às necessidades exigidas pelo mundo atual. 
$E$, finalmente, um outro dado bem interessante foi revelado na questão relacionada à substituição do homem pelo microcomputador, inclusive com sua não participação futura nas atividades presenciais das escolas.

Você acha que, no futuro, será possível aprender tudo com um microcomputador e não mais participar das atividades presenciais nas escolas?

SIM: $8(16 \%)$ NÃO: 42 (84\%)

Entre as respostas apresentadas, aproximadamente $15 \%$ dos professores justificam a necessidade das atividades presenciais através da função complementar ou auxiliar do computador no ensino. Outras respostas, da ordem de $20 \%$, justificam sua resposta apenas citando que 0 professor é insubstituível.

Cerca de $25 \%$ dos professores dessa pesquisa indicam a importância da interatividade social, seja entre alunos, seja entre alunos e professores ou mesmo entre aluno e escola. Os exemplos de respostas são:

"É possível aprender muito, mas, tudo não! Ter um bom relacionamento, trabalho em equipe etc, o colégio contribui muito com isso." (A26)

"Não, a presença do professor ainda é fundamental, pois o fator emocional e psico-pedagógico influencia muito no aprendizado."

"Não. O aluno tem que ser integrado no meio social onde vive e a escola pode muito bem fazer esse papel." (A24)

"Não. Assim como não há movimento sem interação, também não há aprendizado sem a integração aluno, professor e tecnologia." (A8)

"Não. O ser humano é insubstituível. Enquanto o microcomputador ensina o intelectual, a parte afetiva desenvolvida nas escolas nunca pode ser superada." (B1)

Finalmente, cerca de $15 \%$ dos professores apresentam suas justificativas sobre a necessidade de atividades presenciais pelo fato de $o$ computador ser uma máquina incompleta em termos de "conhecimento", conforme os exemplos de respostas abaixo: 
"Não. O computador não é completo e não pode substituir 0 raciocínio humano." (B6)

"Não, pois utilizar somente o computador significa que ele passaria a programar o homem para executar atividades o que é improvável. Fugiríamos da realidade."

"Não o raciocínio de uma máquina acho que não chegaria a se equivaler com o raciocínio humano." (B5)

"Não. Pense você. Porque a máquina só tem $5 \%$ da mente humana. A máquina só serve para facilitar o homem e não pará-lo e torná-lo incapaz de suas atividades cotidianas." (B10)

"Acredito que não, pois os cálculos e programas, podem não vir detalhadamente, necessitando assim de um instrutor capacitado sempre que isso ocorrer." (A5)

\section{II.2.1 Laboratório de informática na escola}

Quando questionados sobre que tipo(s) de laboratório(s) eles gostariam de ter em sua escola, embora o questionário possibilitasse a escolha do(s) laboratório(s) de preferência, cerca 30\% dos professores assinalaram todos as opções. As razões dessa escolha estão apresentadas nos exemplos de respostas abaixo:

"Todos são importantes para uma 'perfeita' melhora do ensino." (A2)

"Todos são indispensáveis $p /$ ensino-aprendizagem."

"Todos são essenciais, porém precisaríamos de um espaço físico e uma organização no uso." (B5)

"Todos são recursos didáticos indispensáveis." (A32)

"O microcomputador é didático e estaria inserido nesse laboratório didático. É a soma de tudo pela boa educação." (B9)

Os exemplos mostram que esses professores consideram todos os laboratórios indispensáveis para o ensino. A totalidade dos professores acredita que uma escola ideal, necessariamente, precisa de microcomputadores (questão 10). Entretanto, a porcentagem deles que escolheu o laboratório de informática foi menor do que a esperada, da ordem de $25 \%$. Chamou a atenção o número significativo de professores, 
também da ordem de 25\%, que escolheu outro tipo de laboratório, principalmente o laboratório experimental.

\subsection{Resultados e considerações}

É bastante nítida a diferença na maneira de se relacionar com os computadores entre os professores de São Paulo e os do Acre. Embora ambos os grupos sejam de professores de Física da rede pública estadual de ensino, pertencendo aproximadamente à mesma faixa etária e com tempo de magistério semelhante, o computador e os seus programas se mostraram muito mais familiarizados nas atividades dos docentes do Acre. Se, nesse grupo, pudemos identificar que cerca de $70 \%$ dos professores utilizam e conhecem os programas básicos de um computador, no grupo de São Paulo esse percentual pouco ultrapassa os $10 \%$.

As razões que poderiam justificar esse resultado podem estar no fato de os professores do Acre, em número significativo, terem a formação inicial em engenharia, trabalhar em setores que envolvem informática e exercer no magistério a sua segunda atividade, diferentemente do grupo de São Paulo que, em sua grande maioria, são licenciados em Matemática e tem como única atividade a docência no ensino médio.

As diferenças nos modos de se relacionar com o computador, em termos de seu uso, fazem com que as percepções sobre o mesmo sejam, de certa forma, diferentes. Para aqueles professores que utilizam ou utilizaram computador com freqüência significativa, o que vem à mente, num primeiro plano, quando se evoca o tema computador, é a sua identificação num contexto mais amplo, seja fazendo parte das várias atividades da vida social, seja mostrando sua presença imprescindível na sociedade moderna. Já para os professores que não conhecem o computador, a sua presença se faz notar mais nitidamente no âmbito escolar, dando a ele importância exagerada, como um "equipamento indispensável" no processo de ensinoaprendizagem ou "ferramenta poderosa" no auxílio da prática pedagógica, talvez exatamente pelo desconhecimento de seu uso prático. 
Quanto à potencialidade do uso do computador, de um modo geral, os professores o identificam como um instrumento que melhora a qualidade das atividades, seja no trabalho profissional, no cotidiano e até no lazer; reconhecem o computador como um equipamento que agiliza e facilita as tarefas, possibilitando a realização de atividades com mais rapidez e com menos dificuldades; e, ainda, vêem o computador como um equipamento que possibilita aquisição de conhecimentos e realização de pesquisas.

A Internet é identificada pelos professores, sejam eles usuários ou não, como uma fonte de pesquisa, de curiosidades, de entretenimento e de aquisição de conhecimentos. Reconhecem também que ela é uma rede de comunicação que possibilita ligação em nível mundial e que esse processo é realizado de forma muito rápida, com velocidade incrível.

No âmbito da educação, os professores identificam fundamentalmente quatro potencialidades para o uso do computador: a primeira, aquela que the auxilia no preparo de suas aulas, facilitando, agilizando e tornando melhor a qualidade das provas ou das apostilas; a segunda, que possibilita, tanto a professores quanto a alunos, pesquisar e obter conhecimento; a terceira, que auxilia o processo de ensino e de aprendizagem possibilitando a apresentação de aulas mais motivadoras com o uso de datashows ou demonstrações áudio-visuais, ou através do uso do computador por parte dos alunos para construção de gráficos, entendimento de fórmulas, simulação de atividades experimentais e utilização de programas específicos da área.

A quarta potencialidade identificada no uso do computador na educação é de natureza bastante diferente das anteriores, pois os professores concebem o computador como um objeto de estudo em si e não como um meio, como as três primeiras anteriores. O computador deve ser parte do processo de educação, não como ferramenta auxiliar do ensino de Física, mas como algo que deve ser utilizado e compreendido, pois ele faz parte do mundo contemporâneo.

Fica bastante evidente para os professores que participaram da pesquisa, que o computador é um instrumento que auxilia, de forma 
bastante ampla, o processo de ensino, que ele nunca substituirá o professor na relação pedagógica, e que nem as atividades presenciais na escola poderão ser abandonadas pelo fato do convívio social ser considerado elemento essencial na formação do aluno. Fica também evidente que um laboratório de informática não é a solução para os problemas do ensino de Física e muitos chegam a dar prioridade ao laboratório experimental ou à biblioteca para a melhoria deste ensino.

Pode-se dizer que os professores compartilham uma visão bastante positiva sobre o uso do computador, e apenas um professor não considera adequado o seu uso excessivo na escola, pois o ensino de Física deve desenvolver outras habilidades como o raciocínio lógico e resolução de problemas. Apesar disso, um grupo significativo de professores do Acre e quase a totalidade de São Paulo vêem esse equipamento com bastante receio e até com temor, por falta de domínio do objeto, seja devido a falta de condições financeiras para adquiri-lo, seja por falta de oportunidade para apreender a dominar o seu uso.

Embora uma parcela significativa dos professores conheça os principais programas do pacote da Microsoft, apenas três professores citam "programas" que de alguma forma estão relacionados ao ensino da Física, que são basicamente banco de dados de vestibulares, de cursinhos e de divulgação (Super Interessante). Ao mesmo tempo, os professores identificam no computador o seu potencial para proposição de atividades de aprendizagem que simulam experiências, constroem gráficos ou resolvem problemas de forma interativa, o que parece indicar a existência de uma ruptura entre a compreensão do objeto e a sua utilização na prática.

Esses resultados sugerem proposições diferenciadas, mas que se complementam, quanto ao uso do computador pelo professor. Para aqueles que já utilizam o computador, a proposição seria a divulgação dos softwares educativos desenvolvidos por grupos de pesquisas em ensino de Física, para auxiliar ou melhorar o ensino em sala de aula, desenvolvendo competências para um uso adequado e eficiente através de atividades de formação de professores. A outra proposição, dirigida para o grupo que não usa o computador, exigiria, num primeiro momento, um trabalho de 
sensibilização, para que o professor perca o receio ou medo do equipamento, num trabalho de formação docente com atividades de aprendizagem de novos conteúdos, sejam de área específica, sejam de educação, sejam de formação geral.

Embora vários projetos, nacional e/ou estadual, procurem inserir o computador na educação de nível médio, os resultados desse trabalho parecem indicar que eles têm sido pouco eficientes, principalmente no Estado de São Paulo. Por outro lado, é também pequeno o alcance dos produtos elaborados pelos grupos de pesquisa, como os softwares educacionais.

Com relação ao uso da informática pelo professor, esta pesquisa parece indicar que o computador, quando utilizado, é apenas concebido como um instrumento auxiliar na educação de uma área específica, e não como um objeto que o professor deve conhecer para se inserir, como um indivíduo participativo, nesse mundo atual e tecnológico. Nessa perspectiva, não se deve entender a tecnologia como algo que complementa a sociedade, mas como algo que faz parte da cultura, e assim, a educação deve conceber o computador fazendo parte de uma nova cultura educacional. 
O trabalho apresentado pode ser considerado o resultado inicial de uma pesquisa e não um trabalho concluído. Isto porque, constantemente, se produzem novas pesquisas que, poderão alimentar outras. Também a análise dos questionários se constitui em um estudo parcial de caso específico. Outras análises poderiam ser feitas. Pensa-se que a pesquisa deve ser entendida como uma contribuição, possibilitando uma melhor compreensão sobre o uso do computador no ensino de Física.

A melhoria da Educação, e especialmente do ensino de Física, não ocorre apenas com ações isoladas e que há necessidade de investimentos, seja público ou privado. Um exemplo é do Projeto EDUCOM que, apesar de envolver apenas cinco Universidades Brasileiras, apresenta uma produção de relatos de trabalhos sobre as relações que permitem a inserção da Informática na Educação, qualificando profissionais e alimentando outras pesquisas em diferentes áreas do ensino. Se o projeto envolvesse mais Universidades, como previsto inicialmente, aproximando ainda mais o professor de seus objetivos, com certeza um quadro ainda mais significativo de produção teórica e prática nesse âmbito poderia ser desenhado atualmente.

A pesquisa mostra que para o computador fazer parte do processo de ensino-aprendizagem, o papel do professor é essencial. $O$ estudo e a reflexão sobre os resultados dos questionários aplicados, possibilitam entender um pouco como esses professores olham essas novas tecnologias educacionais. Esse olhar é bastante positivo com relação ao uso do computador, mas, de uma forma geral, por falta de domínio do objeto, ainda há bastante receio e temor com relação ao seu uso, o que também ocorre com a Internet.

Embora o uso dos microcomputadores já estarem de determinada maneira no nosso dia-a-dia a mais de 10 anos e inserido no nosso cotidiano e nos meios educacionais, aquela visão de Pierre Levy ainda parece estar longe do alcance dos usuários dessas tecnologias, em especial dos 
professores pesquisados. A mudança ainda não está no plano dessa nova cultura cibernética, pois mesmo os professores percebendo a necessidade de se inserir à esses novos conhecimentos e detectando problemas como de formação, foi possível perceber que essa forma ainda não se aproxima à reflexão proposta da utilização do computador na Educação.

Uma estratégia para a incorporação de computadores à Educação, deve ser primeiramente voltada para a formação dos professores em informática, apresentando e desenvolvendo atividades informativas e formativas, práticas e teóricas que proporcionem familiaridade e confiança com e sobre o sistema computacional (hardware e software, ou seja, máquinas e programas). Pois, somente se familiarizados com o sistema computacional, os professores estarão aptos a planejar a integração do computador com as atividades relacionadas ao currículo, garantindo com isso uma participação ativa no processo de implementação da informática na escola.

Nessa perspectiva o uso do computador em Educação no qual a atuação do professor não se limita somente a fornecer informações aos alunos, mas também assume as mediações das interações professor-alunocomputador de modo que o aluno também possa construir o seu conhecimento em um ambiente desafiador, em que o computador passa a auxiliar o professor a promover o desenvolvimento da autonomia, da criatividade, da criticidade e da auto-estima do aluno, como proposto por Almeida.

Dessa maneira, parece estar longe da realidade dos professores pesquisados esses tipos de características, pois deixam claro que necessitam de cursos, oficinas e mais prática para a utilização do computador, deixando bem distante todas essas reflexões.

Assim percebe-se hoje que a formação e a atuação de professores para o uso da Informática em Educação é um processo que acaba interrelacionando o domínio dos recursos tecnológicos com a ação pedagógica e como destacado por Almeida (1997) com os conhecimentos teóricos necessários para refletir, compreender e transformar essa ação.

Para tornar possível tal transformação seguida de uma reflexão na atuação do professores seria necessário que ele (professor) vivenciasse 
situações em que pudessem analisar sua prática e a de outros professores, estabelecendo relações entre elas e as teorias de desenvolvimento subjacentes, participando de reflexões coletivas sobre as mesmas, discutindo suas perspectivas com os colegas e buscando novas orientações.

A associação entre a ação e formação (inicial ou continuada) tornase viável no momento em que se rompe com a seqüência hierárquica de conteúdos que caracteriza a formação tradicional e se assume a postura problematizadora que provoca a criação de redes de significados tecidas em meio a ações e reflexões. Desta forma, o professor vivencia a aprendizagem de seus alunos, tendo a oportunidade de tomar consciência e de discutir sobre como se aprende e como se ensina, de descobrir potencialidade de aprender a partir dos próprios erros e de reconstruir continuamente teorias.

É notório na análise dos dados, que os professores acreditam que essa inserção tecnológica na educação é benéfica. Até mesmo para aqueles que não conhecem o computador e a Internet, apesar do fascínio com a rapidez e alcance das informações proporcionados por esses meios (sociedade da informação), a presença do professor é indispensável no processo educativo. Além disso, o laboratório de informática não é defendido como uma ferramenta/meio essencial numa escola, sendo preferido, em alguns casos, pela instalação do laboratório experimental.

Dessa maneira, o discurso ainda é a ferramenta principal que o professor utiliza para conduzir o processo de ensino, controlando os sentidos produzidos e negociando os significados em construção. E os computadores também são importantes para estabelecer relações e despertar vários processos internos de desenvolvimento, possibilitando a aprendizagem e o desenvolvimento dos alunos junto ao discurso do professor/mediador.

É relevante também que o professor planeje sua aula, pois reproduzir livros didáticos, ou simplesmente simular atividades através de um software didático, não possibilitará a aprendizagem do aluno, pois é preciso que o conteúdo apresentado lhe seja significativo. O significado da aprendizagem de determinado conteúdo encontra-se presente no meio social/cultural do aluno, de sua vivência, sendo de competência do professor planejar e organizar didaticamente os conceitos a serem ministrados, com 
liberdade de escolha de ferramentas oportunas para o desenvolvimento de sua aula, podendo utilizar o computador quando julgar importante.

Observa-se que mudanças pedagógicas devem acontecer e são necessárias nas escolas, principalmente na compreensão de que Física ensinar. Esta compreensão deveria atender a uma concepção epistemológica de que a Física é uma produção humana e social. Não adianta modernizar a Educação, com o computador, se a concepção sobre o que ensinar de Física e da própria Ciência Física persistir a mesma do velho quadro de giz. É possível trazer os avanços científicos e tecnológicos para o contexto da sala de aula, buscando mostrar o que é relevante, qual sua função na sociedade e sua utilidade possibilitando novas produções/criações pelos alunos.

Outra constatação refere-se ao uso da Internet, e já há pesquisas que destacam a sala de aula virtual. Pouco se sabe sobre o uso que se faz da informação disponível nos planos de aula de Física, porém é preciso entender como as criações/recriações dos conceitos em Física são possíveis através da Internet, e isto exige novas pesquisas em relação ao ensino de Física e o computador.

Melhorar o ensino de Física está sendo um desafio, e por hora muito difícil. Dentre muitos motivos, um deles é porque o professor não tem acesso a muitas informações atuais, como os resultados de pesquisas educacionais, sendo indispensável, para isso uma aproximação maior dos mesmos em encontros, simpósios, congressos etc..

É preciso haver interação do professor com outros professores/pesquisadores, para que ele possa produzir e avaliar o seu material de ensino, analisar as suas aulas e recriar novas possibilidades de aprendizagem ao aluno. Pelos trabalhos analisados do XV SNEF, algumas pesquisas já mostram a participação efetiva do professor do ensino médio com apresentação de trabalhos e interação nos cursos e oficinas. A abertura de novos espaços alternativos, de socialização de experiências, onde seja possível apresentar resultados investigativos, pode inserir o professor atuante cada vez mais em projetos do meio acadêmico. Essa aproximação parece ser uma boa alternativa, pois é na academia que, na maioria das vezes, as reflexões dessas novas formas de ensino acabam sendo 
discutidas e realizadas, podendo contribuir para a formação do professor, ao mesmo tempo em que este pode contribuir para o sucesso dos projetos.

De forma geral, esse trabalho teve como foco algumas questões pertinentes à produção de um novo conhecimento em ensino de Física, especificamente através do computador, verificando inclusive como tem sido proposta a formação dos professores nesse contexto. Tudo isso, por sua vez, remeteu a uma revisão do fazer pedagógico, vislumbrando novos horizontes, deixando claro que muitas vezes não é um equipamento ou programa que possibilita substituir um bom projeto pedagógico. A consistência do processo de ensino-aprendizagem está em uma prática de sala de aula centrada em interações e em mediações, onde residem possibilidades concretas de aprendizagem, onde o sucesso de criação e recriação requer, antes de mais nada, um ambiente favorável e um bom mediador. 


\section{REFERÊNCIAS BIBLIOGRÁFICAS}

ALMEIDA, M. E. O computador como ferramenta de reflexão na formação e na prática pedagógica. São Paulo, Revista da APG, PUC/SP, ano VI, n. 11, 1997.

ALMEIDA, M. ELIZABETH.; Informática e formação de professores (volume 2); Série de Estudo - Educação a distância; Secretaria da Educação (Org.); Proinfo; Brasília , 2000.

ARAUJO, M; Uso de Redes em Educação REDEGURI: Uma Experiência Fascinante; Anais III SBIE, Sette, S. (Org.); Recife, Pernambuco. outubro, 1992.

ASSIS, R. et al.; O Uso do PUCLOGO e a Adaptação do Lego Logo e do Voyage of the Mimi para 2a., 3a. e 4a. Séries do Primeiro Grau; Projeto para o CNPq; Departamento de Educação, PUC/RJ; Rio de Janeiro; 1991.

ATAS e resumos do X Simpósio Nacional de Ensino de Física: tempo de avaliação, Londrina: 25 a 29 de Janeiro de 1993.

ATAS e resumos do XI Simpósio Nacional de Ensino de Física: tempo de mudança, Niterói: UFF, 23 a 27 de Janeiro de 1995.

ATAS e resumos do XII Simpósio Nacional de Ensino de Física: Novos horizontes: educação permanente, novas tecnologias e inovações tecnológicas, Belo Horizonte: UFMG, 27 a 31 de Janeiro de 1997.

ATAS e resumos do XIII Simpósio Nacional de Ensino de Física: em busca de sua identificação: Unb, 25 a 29 de Janeiro de 1999.

ATAS e resumos do XIV Simpósio Nacional de Ensino de Física. Educação Científica, cultura e qualidade de vida, Natal: UFRN, 02 a 06 de Julho de 2001.

ATAS e resumos do XV Simpósio Nacional de Ensino de Física. O tema foi "O ensino de física: presente e futuro". Curitiba. UFPR, 21 a 26 de Março de 2003. 
BRIZZI, Maristela L. S. A Educação em Física mediada pelo computador. Mestrado em Educação nas Ciências. Editora Inijuí, Rio Grande do Sul, 2000.

CAMPOS, G.H.B. e ROCHA, A.R.C.; Manual para Avaliação do Software Educacional. Publicações Técnicas; Programa de Engenharia de Sistemas e Computação; COPPE/UFRJ; Rio de Janeiro; 1990.

CAMPOS, G.H.B. e ROCHA, A.R.C.; Critérios de Avaliação do Uso do Computador como Tutor; Publicações Técnicas; Programa de Engenharia de Sistemas e Computação. COPPE/UFRJ; Rio de Janeiro; 1991.

CANDAU, D. "Intel Educação para o futuro com suporte Microsoft", Institute of Computers of Technology., 2001.

CHRISTESEN, L. e STOKES, G.; Design Strategies for a Computer-Based Instruction System; ACM, pp. 329/333; 1986.

CHANT, V.G. e ATKINSON, R.G.; Application of Learning Models and Optimization Theory to Problems of Instruction; Handbook of Learning and Cognitive Process; Hillsdale, N.J. Lawrence Erlbaum; 1978.

CHAVES., E.; O Que é Software Educacional ?; Revista INFO, p.22; janeiro, 1987

CORREIA, J. A. Inovação pedagógica e formação de professores. 2. ed. Rio Tinto, Portugual, Asa, 1991 (pg.18).

FERRACIOLI, Laércio. Novas Tecnologias. In: ATAS do XI Simpósio Nacional de Ensino de Física: tempo de mudança, Niterói: UFF, 23 a 27 de Janeiro de 1995.

FORMAN, J.L.; PUCLOGO - Um ambiente Integrado de Ferramentas Voltado para a Educação; Anais II SBIE, Stahl, M. (Org.); Rio de Janeiro; outubro, 1992.

GASPERETTI, M. Computador na Educação: guia para o ensino com as novas tecnologias, Editora Esfera, São Paulo, 2001. 
KILLNER, G. I. Microcomputadores no ensino de física. Dissertação de Mestrado, São Paulo, FE/IF, USP, 1993.

LÉVY, P. As tecnologias da inteligência: o futuro do pensamento na era da informática. Rio de Janeiro, Editora 34, 1993.

LIMA, J.C.M.; Interfaces Inteligentes; Proposta de Tese de Mestrado; Departamento de Informática, PUC-Rio; Rio de Janeiro; 1988.

LUCENA, C.J.P. et alli.; A Informática vai à Escola; Projeto da Secretaria de Ciência e Tecnologia e PUC-Rio; Rio de Janeiro; 1988.

LUCENA, L. R., CAVALCANTE, E. S., SOUZA M. de O., e NOBRE M. C. D. P., O computador como ferramenta para ensino do conceito de vida. In: $\mathrm{X}$ Simpósio Nacional de Ensino de Física: tempo de avaliação, Londrina, p. 177 - 179, 25 a 19 de janeiro de 1993.

LUCENA, M.; Uma Análise da Informática na Educação no Brasil: O Caso do Município do Rio de Janeiro; Publicações Técnicas; Programa de Engenharia de Sistemas e Computação; COPPE/UFRJ; Rio de Janeiro; junho, 1994.

LUCENA, M.; Relatório de Avaliação do II Encontro da Informática com a Educação; Relatório Técnico para IBM Brasil e Unisys Brasil; II Encontro da Informática com a Educação; Faculdade Carioca; Rio de Janeiro; 1994.

LUCENA, M.; A Gente é uma Pesquisa: Desenvolvimento Cooperativo da Escrita Apoiado pelo Computador; Dissertação de Mestrado; Departamento de Educação, PUC-Rio; Rio; Rio de Janeiro; abril, 1992.

LUCENA, M.; Comunidades Dinâmicas para o Aprendizado na Internet; Revista Brasileira de Informática na Educação; Sociedade Brasileira de Computação; http://www.inf.ufsc.br/sbc-ie/revista/nr2/indice.htm; no.2; abril, 1998.

LUCENA, M.; Uma Escola Aberta na Internet: Kidlink no Brasil; Editora Brasport: Rio de Janeiro e http://venus.rdc.puc-rio.br/kids/kidlink; 1997.

MACHADO, N. J. Epistemologia e didática: as concepções de conhecimento e inteligência e a prática docente. São Paulo. Cortez, 1995. 
MACHADO, N. J. Tópicos de Epistemologia e Didática. Editora escrituras. Terceira Edição; São Paulo, Novembro 1999.

MEC/Brasil; "Projeto Proinfo: Programa Nacional de Informática na Educação"; http://www.mec.gov.br/Organiza/or_frm.htm; 1997

MINISTÉRIO DA EDUCAÇÃO. Programa Nacional de Informática e Educação, Brasília, $1999 . \quad$ Disponível em: http://www.proinfo.gov.br/prf descricao.htm\#objetivos

MORAES, Maria C. Informática Educativa no Brasil: um pouco de história. Brasília: Em aberto, ano 12, oㅡ 57, jan/mar. 1993, p. 16-27

MORIN, E. Ciência com consciência. Rio de Janeiro, Bertrand, Brasil, 1996.

NEGROPONTES, NICHOLAS. A vida digital. Companhia das Letras, $2^{\text {a }}$ Edição, São Paulo - 2000

NISKIER, A.; O Papel e a Proposta da Faculdade Carioca para a Formação de Recursos Humanos na Área da Educação e Informática; Anais II Encontro da Educação com a Informática; Lucena, M. (Org.); Faculdade Carioca; Rio de Janeiro; outubro, 1993.

NÓVOA, A. (org) Os professores e sua formação. Lisboa, Dom Quixote, 1992.

PROJETO DE EDUCAÇÃO À DISTÂNCIA EN CIÊNCIA E TECLOLOGIA: EDUCANDI (Fagundes, L.; Coord.); http://www.infosoft.softex.br/ projeead; 1998.

PAPERT, S.; LOGO: Computadores e Educação; Ed. Brasiliense: São Paulo; 1985.

PRETTO. Nelson de L. Uma escola sem com futuro: educação e multimídia. Campinas, Papirus, 1996, 247p.

ROSA, P. R. da S. O uso do computador no Ensino de Física. Parte 1: Potencialidade e uso real. RBEF, vol. 17, no 2, Junho de 1995.

REVISTA ACESSO. Revista de educação e informática. Abril 1999 - n. 13. 
REVISTA BRASILEIRA DE ENSINO DE FÍSICA, São Paulo, SP, de 1993 a 2002

REZENDE, F. Aprendizagem baseada em casos na formação continuada a distancia de professores de física: contribuições do estudo de uma situação presencial, In: Resumos do VII Encontro de Pesquisa em Ensino de Física, SBF, Florianópolis, março de 2000.

REZENDE, F. Desenvolvimento e avaliação de um sistema hipermídia para facilitar a reestruturação conceitual em Mecânica Básica, In: Caderno Catarinense de Ensino de Física, vol. 18, nº 2, agosto de 2001.

RIPPER, A. V. e e outros. O projeto "Eureka", in VALENTE, J. A. (org). Computadores e conhecimento: repensando a educação. Campinas, Gráfica Central da Unicamp, 1993.

ROCHA, A.R.C. e SANTOS, N.; A Formação de Recursos Humanos em Informática na Educação; Anais II Encontro da Informática com a Educação, Lucena, M. (Org.); Faculdade Carioca; Rio de Janeiro; outubro, 1993.

ROSA, Paulo R. S.. O uso de computadores no ensino de Física. Parte I: Potencialidades e usos real. In: Revista Brasileira de Ensino de Física, Florianópolis, SC, Vol. 17, nº 2, junho, 1995.

SANTOS, N.; Aprendizagem Cooperativa à Distância: Notas Avulsas; http://venus. rdc.puc-rio.br/kids/kidlink/acd/texto.htm; 1998.

SETZER, VALDEMAR W.; Meios eletrônicos e Educação: Uma visão alternativa; Coleção Ensaios Transversais, Editora Escrituras; São Paulo, 2001.

STRATHERN, PAUL; Turing e o computador em 90 minutos. Jorge Zahar Editor; Tradução de Maria Luiza X. de a Borges; Rio de Janeiro; 2000.

TAJRA, Sanmya F. Informática na Educação: Novas ferramentas Pedagógicas para o Professor da Atualidade. 2 ed. Ver., atual. E ampl., São Paulo: Érica, 2000, 143p.

TAGIKU, A. M.; Os microcomputadores no ensino: O ponto de vista dos alunos; Tese de mestrado, IFUSP, São Paulo, 2001. 
TENÓRIO, ROBINSON; Computadores de papel: Máquinas abstratas para um ensino concreto. Cortez Editora; Série Questões de nossa época (vol 80); ABDR - 2ª Edição; São Paulo; 2001.

TENÓRIO, ROBINSON; Cérebros e computadores: A complementaridade analógico-digital na informática e na educação. Ensaios Transversais; Editora Escrituras; São Paulo; 1998.

TORNAGHI, A., VENICIO, M., e REINACH M. de C. Robótica no ensino de Física. In: ATAS do XI Simpósio Nacional de Ensino de Física: tempo de mudança, Niterói: UFF, 23 a 27 de Janeiro de 1995.

VALENTE, J. A. (org.) Computadores e conhecimento: repensando a educação. Campinas, Gráfica central da UNICAMP, 1993, 418p.

VEIT, E. A. \& TEODORO V. D. Modelagem no Ensino Aprendizagem de Física e os Novos Parâmetros Curriculares Nacionais para o Ensino Médio, In: Revista Brasileira de Física, SBF, vol. 24, ㄲo 2, junho de 2002. 


\section{ANEXOS}

\section{I.1 SIMPÓSIOS}

X Simpósio Nacional de Ensino de Física

XI Simpósio Nacional de Ensino de Física

XII Simpósio Nacional de Ensino de Física

XIII Simpósio Nacional de Ensino de Física

XIV Simpósio Nacional de Ensino de Física

XV Simpósio Nacional de Ensino de Física

\section{II.2 REVISTA BRASILEIRA DE ENSINO DE FÍSICA}

\section{I.1 QUESTIONÁRIO DE SÃO PAULO}

3.I.2 QUESTIONÁRIO DO ACRE

3.II ANÁLISE DAS RESPOSTAS DOS PROFESSORES DO ACRE

3.II.1 O computador / potencialidades

3.II.2 Internet

3.II.3 Como os professores se vêem e pensam diante das novas tecnologias

3.II.4 Educação 


\section{ANEXO 2.I.1}

\section{Simpósio Nacional de Ensino de Física}

Tabela dos Cursos e Oficinas oferecidos no evento que utilizaram os recursos tecnológicos para a sua realização, destinados como oficinas de Informática.

\begin{tabular}{|l|l|l|}
\hline \multicolumn{1}{|c|}{ Título do Curso/Oficina } & \multicolumn{1}{|c|}{ Autores } & $\begin{array}{c}\text { Instituição / } \\
\text { Universidade }\end{array}$ \\
\hline $\begin{array}{l}\mathrm{C}^{16} 16 \text { - Novas tecnologias no ensino de } \\
\text { física }\end{array}$ & Gustavo I. Killner & IFUSP \\
\hline
\end{tabular}

Os trabalhos apresentados em forma de Painéis e Comunicações Orais relevantes para a pesquisa realizada estarão apresentados abaixo, com seus respectivos códigos (de acordo com o Livro de Programas e Resumos do X-SNEF) e relacionados aos seus respectivos eixos, como utilizado para a classificação no trabalho.

\begin{tabular}{|c|c|}
\hline Eixos & Códigos dos trabalhos \\
\hline Softwares & $\begin{array}{l}\text { CO }^{17} . \text { SEG.110, CO.QUI.109-1, CO.QUI.109-2, } \\
\text { CO.QUI.109-4, CO.QUI.109-5, PNI.109-3, } \\
\text { PN.TER.155A3 e PN.TER.155A4. }\end{array}$ \\
\hline Internet & Nenhum trabalho foi apresentado com essa abordagem \\
\hline $\begin{array}{c}\text { Formação } \\
\text { do } \\
\text { Professor }\end{array}$ & Nenhum trabalho foi apresentado com essa abordagem \\
\hline
\end{tabular}

\section{$\underline{\text { XI Simpósio Nacional de Ensino de Física }}$}

\footnotetext{
${ }^{17}$ Cursos (nomenclatura adotada no livro de resumo)

${ }^{17}$ Comunicação Oral

${ }^{18}$ Painel
} 
Tabela dos Cursos e Oficinas oferecidos no evento que utilizaram os recursos tecnológicos para a sua realização, destinados como oficinas de Informática.

\begin{tabular}{|c|c|c|}
\hline Título do Curso/Oficina & Autores & $\begin{array}{l}\text { Instituição / } \\
\text { Universidade }\end{array}$ \\
\hline $\begin{array}{l}\mathrm{B}^{19} 5 \mathrm{~T}^{20}-\text { Autoria de Hipermídia no Ensino } \\
\text { de Física }\end{array}$ & $\begin{array}{l}\text { João Carlos } \\
\text { Nogueira Alves }\end{array}$ & ETFQ/RJ \\
\hline B22T - Robótica no Ensino de Física & $\begin{array}{l}\text { Alberto Tornaghi, } \\
\text { Marcos Venicio, } \\
\text { Monica de Castro } \\
\text { Reinach }\end{array}$ & ECV/CSI/CECI \\
\hline $\begin{array}{l}\text { B26M - Uso de Interfaces no Laboratório } \\
\text { Didático de Física }\end{array}$ & $\begin{array}{l}\text { João Carlos } \\
\text { Nogueira Alves }\end{array}$ & ETFQ \\
\hline $\begin{array}{l}\text { B27M - Usos de computação algébrica no } \\
\text { Ensino de Física via Maple }\end{array}$ & Renato Portugal & CBPF \\
\hline $\begin{array}{l}\text { D1T - Organização de grupos de interesse } \\
\text { em comunicação eletrônica via Internet }\end{array}$ & $\begin{array}{l}\text { Maria C. Dal Pian, } \\
\text { Marcilio Colombo } \\
\text { Oliveros, Gledson } \\
\text { Elias da Silveira e } \\
\text { Ana Lúcia Gomes }\end{array}$ & UFRN \\
\hline
\end{tabular}

Os trabalhos apresentados em forma de Painéis e Comunicações Orais relevantes para a pesquisa realizada estarão apresentados abaixo, com seus respectivos códigos (de acordo com o Livro de Programas e Resumos do XV-SNEF) e relacionados aos seus respectivos eixos, como utilizado para a classificação no trabalho.

\begin{tabular}{|c|l|}
\hline Eixos & Códigos dos trabalhos \\
\hline Softwares & CO $^{21}$. B3.8, CO.B3.9 e P.B2.7. \\
\hline Internet & $\mathrm{P}^{22}$. B2.9 e P.C2.11. \\
\hline
\end{tabular}

\footnotetext{
${ }^{19}$ Significa em que eixo essa oficina está classificada no Simpósio (A - Enfoques curriculares, B - Ensino-aprendizagem, C - Formação do professor e do pesquisador e D Divulgação)

${ }^{20}$ Período da oficina ( $\mathrm{M}$ - Manhã e $\mathrm{T}$ - Tarde)

${ }^{21} \mathrm{CO}$ - Comunicação oral

${ }^{22} \mathrm{P}$ - Painel
} 


\begin{tabular}{|c|c|}
\hline $\begin{array}{c}\text { Formação } \\
\text { do } \\
\text { Professor }\end{array}$ & Nenhum trabalho foi apresentado com essa abordagem \\
\hline
\end{tabular}

\section{Simpósio Nacional de Ensino de Física}

Os trabalhos apresentados em forma de Painéis e Comunicações Orais relevantes para a pesquisa realizada estarão apresentados abaixo, sendo utilizado o número da página da ata que o mesmo está exposto, uma vez que não tem sigla, e assim relacionados aos seus respectivos eixos, como utilizado para a classificação no trabalho.

\begin{tabular}{|c|l|}
\hline Eixos & \multicolumn{1}{|c|}{ Códigos dos trabalhos } \\
\hline Softwares & $\begin{array}{l}70,96,110(2), 111(2), 112,113(2), 114(2), 133,145(2), 146(3), \\
147(3) .\end{array}$ \\
\hline Internet & 68 e 112 \\
\hline $\begin{array}{c}\text { Formação } \\
\text { do } \\
\text { Professor }\end{array}$ & Nenhum trabalho foi apresentado \\
\hline
\end{tabular}

\section{Simpósio Nacional de Ensino de Física}

Tabela dos Cursos e Oficinas oferecidos no evento que utilizaram os recursos tecnológicos para a sua realização, destinados como oficinas de Informática.

\begin{tabular}{|c|c|c|}
\hline Título dos Mini Cursos & Autores & $\begin{array}{l}\text { Instituição / } \\
\text { Universidade }\end{array}$ \\
\hline $\begin{array}{l}\text { Minicurso A4 - Novas tecnologias no } \\
\text { ensino de física: experimentação assistida } \\
\text { por computador }\end{array}$ & $\begin{array}{l}\text { Prof }{ }^{a} . \\
\text { Cavalcante, Prof }{ }^{a} . \\
\text { Cristiane R. C. } \\
\text { Tavolaro }\end{array}$ & PUC-SP \\
\hline Minicurso A14 - Princípios de sistemas e o & Prof. Arion de & UFRGS \\
\hline
\end{tabular}




\begin{tabular}{|l|l|l|}
\hline $\begin{array}{l}\text { uso do programa STELLA for Windows, em } \\
\text { modelos sobre gerenciamento e física. }\end{array}$ & $\begin{array}{l}\text { Castro Kurtz dos } \\
\text { Santos }\end{array}$ & \\
\hline $\begin{array}{l}\text { Minucurso A15 - Ensino mediado por } \\
\text { computadores }\end{array}$ & $\begin{array}{l}\text { Prof. Gustavo I. } \\
\text { Killner }\end{array}$ & IFUSP \\
\hline
\end{tabular}

Os trabalhos apresentados em forma de Painéis e Comunicações Orais relevantes para a pesquisa realizada estarão apresentados abaixo, com seus respectivos códigos (de acordo com o Livro de Programas e Resumos do XIII SNEF) e relacionados aos seus respectivos eixos, como utilizado para a classificação no trabalho.

\begin{tabular}{|c|l|}
\hline Eixos & \multicolumn{1}{c|}{ Códigos dos trabalhos } \\
\hline Softwares & $\begin{array}{l}\mathrm{P}^{23} 1.1, \mathrm{P} 1.2, \mathrm{P} 1.8, \mathrm{P} 1.9, \mathrm{P} 1.10, \mathrm{P} 1.11, \mathrm{P} 3.6, \mathrm{P} 4.9, \mathrm{P} 6.8, \mathrm{P} 8.1, \mathrm{P} 8.2, \\
\mathrm{P} 8.3, \mathrm{P} 8.5, \mathrm{P} 8.7, \mathrm{P} 8.9, \mathrm{P} 8.10 \text { e P10.4. }\end{array}$ \\
\hline Internet & $\mathrm{P} 1.3, \mathrm{P} 1.4, \mathrm{P} 1.5, \mathrm{P} 6.6, \mathrm{P} 8.4, \mathrm{P} 8.6, \mathrm{P} 8.8$ e P8.11. \\
\hline $\begin{array}{c}\text { Formação } \\
\text { do } \\
\text { Professor }\end{array}$ & $\mathrm{P} 1.6$ e P1.7, \\
\hline
\end{tabular}

Abaixo estão apresentados os temas dos trabalhos relacionados com o uso do computador na Educação em Física que destacavam uma maior preocupação com a formação do professor.

\begin{tabular}{|l|l|l|}
\hline \multicolumn{1}{|c|}{ Tema do Trabalho apresentado } & \multicolumn{1}{|c|}{ Autores } & $\begin{array}{c}\text { Instituição / } \\
\text { Universidade }\end{array}$ \\
\hline $\begin{array}{l}\text { P1.6 - Uma proposta para ensino de } \\
\text { ciência: projeto WBL }\end{array}$ & $\begin{array}{l}\text { Gustavo } \\
\text { Killner }\end{array}$ & FEUSP \\
\hline $\begin{array}{l}\text { P1.7 - O professor como prático reflexivo: } \\
\text { uma aplicação ao desenvolvimento } \\
\text { profissional do professor via Internet }\end{array}$ & $\begin{array}{l}\text { David e Oto Néri } \\
\text { Borges }\end{array}$ & UFMG \\
\hline
\end{tabular}

\section{Simpósio Nacional de Ensino de Física}

Tabela dos Cursos e Oficinas oferecidos no evento que utilizaram os recursos

\footnotetext{
${ }^{23}$ Painel (segundo a nomenclatura do livro de resumo)
} 
tecnológicos para a sua realização, destinados como oficinas de Informática.

\begin{tabular}{|c|c|c|}
\hline Título do Curso/Oficina & Autores & \begin{tabular}{|l|} 
Instituição / \\
Universidade
\end{tabular} \\
\hline $\begin{array}{l}\text { Curso } 02 \text { - Princípio de sistemas e o uso } \\
\text { do programa "Stella for Windows" em } \\
\text { modelos relacionados à Física }\end{array}$ & $\begin{array}{llr}\text { Prof. } & \text { Arion } & \text { de } \\
\text { Castro } & \text { Kurtz } & \text { dos } \\
\text { Santos } & & \end{array}$ & \\
\hline $\begin{array}{l}\text { Curso } 12 \text { - Leis de Newton através do } \\
\text { software PROMETEUS }\end{array}$ & $\begin{array}{l}\text { Prof. Umbelina J. } \\
\text { Pibelli }\end{array}$ & UFMS \\
\hline $\begin{array}{l}\text { Oficina } 05 \text { - Construção de uma aula com } \\
\text { recursos de tecnologias da informação. }\end{array}$ & $\begin{array}{lr}\text { Deise } & \text { Miranda } \\
\text { Vianna e } & \text { Renato } \\
\text { Santos Araújo }\end{array}$ & UFRJ \\
\hline $\begin{array}{l}\text { Oficina } 06-\text { Educação tecnológica: } \\
\text { desvelando a reprodução de informações } \\
\text { num cd-player }\end{array}$ & $\begin{array}{l}\text { Fábio da Purificação } \\
\text { de Bastos e Wagner } \\
\text { D. José }\end{array}$ & \\
\hline $\begin{array}{l}\text { Oficina } 12 \text { - Novas tecnologias no ensino } \\
\text { de física. }\end{array}$ & $\begin{array}{lr}\text { Marisa } & \text { A. } \\
\text { Cavalcante } & \mathrm{e} \\
\text { Cristiane } & \mathrm{R} . \\
\text { Tavolaro } & \end{array}$ & PUC-SP \\
\hline $\begin{array}{l}\text { Oficina } 18-\text { Desenvolvimento } \text { de } \\
\text { programas de multimídia e páginas na } \\
\text { Internet para o ensino de Física. }\end{array}$ & $\begin{array}{l}\text { Marcelo de Oliveira } \\
\text { Souza }\end{array}$ & \\
\hline $\begin{array}{l}\text { Oficina } 25 \text { - Software para a edição de } \\
\text { fórmulas e seu uso no ensino de física. }\end{array}$ & $\begin{array}{l}\text { Andréa } \\
\text { Rodrigues }\end{array}$ & UFRN \\
\hline
\end{tabular}

Os trabalhos apresentados em forma de Painéis e Comunicações Orais relevantes para a pesquisa realizada estarão apresentados abaixo, com seus respectivos códigos (de acordo com o Livro de Programas e Resumos do XIV-SNEF) e relacionados aos seus respectivos eixos, como utilizado para a classificação no trabalho.

\begin{tabular}{|c|c|}
\hline Eixos & Códigos dos trabalhos \\
\hline Softwares & $\mathrm{P} 033, \mathrm{P} 008, \mathrm{P} 077, \mathrm{P} 081, \mathrm{P} 087, \mathrm{P} 100, \mathrm{P} 123, \mathrm{P} 147, \mathrm{P} 163$ e P173. \\
\hline
\end{tabular}




\begin{tabular}{|c|l|}
\hline Internet & P005, P056, P058, P146, P185 e P223. \\
\hline $\begin{array}{c}\text { Formação } \\
\text { do } \\
\text { Professor }\end{array}$ & P039. \\
\hline
\end{tabular}

Abaixo estão apresentados os temas dos trabalhos relacionados com o uso do computador na Educação em Física que destacavam uma maior preocupação com a formação do professor.

\begin{tabular}{|c|c|c|}
\hline Tema do Trabalho apresentado & Autores & $\begin{array}{l}\text { Instituição / } \\
\text { Universidade }\end{array}$ \\
\hline $\begin{array}{l}\text { P039 - Atividades de educação continuada } \\
\text { junto a docentes e alunos do ensino médio } \\
\text { utilizando o computador como instrumento } \\
\text { de ensino e pesquisa }\end{array}$ & $\begin{array}{l}\text { Tânia C. A. M. de } \\
\text { Azevedo, } \\
\text { Maurício } \\
\text { Ramos }\end{array}$ & UNESP \\
\hline
\end{tabular}

\section{Simpósio Nacional de Ensino de Física}

Tabela dos Cursos e Oficinas oferecidos no evento que utilizaram os recursos tecnológicos para a sua realização, destinados como oficinas de Informática.

\begin{tabular}{|c|c|c|}
\hline Título do Curso/Oficina & Autores & $\begin{array}{l}\text { Instituição / } \\
\text { Universidade }\end{array}$ \\
\hline IF $^{24}$-01 Ótica e Geometria Dinâmica & $\begin{array}{ll}\text { Carlos } & \text { Eduardo } \\
\text { Aguiar } & \end{array}$ & IFUFRJ \\
\hline $\begin{array}{l}\text { IF-02 Uma sugestão para ensinar-aprender } \\
\text { tópicos de eletromagnetismo investigando a } \\
\text { telefonia celular }\end{array}$ & $\begin{array}{l}\text { José A. P. Angotti, } \\
\text { Rejane A. Mion }\end{array}$ & UFSC/UEPG \\
\hline IF-03 Astronomia: metodologia de ensino & Cleiton J. B. Lattari & $\begin{array}{l}\text { FEMA- } \\
\text { UNIFIL }\end{array}$ \\
\hline IF-04 Luzes e cores & $\begin{array}{l}\text { Marilia P. Linhares, } \\
\text { Ernesto M. Reis }\end{array}$ & UENF-CEFET \\
\hline $\begin{array}{l}\text { IF-05 Exemplo do uso de um software no } \\
\text { Ensino de eletricidade }\end{array}$ & $\begin{array}{l}\text { Roberta M. Miranda, } \\
\text { Juliana }\end{array}$ & IFUSP \\
\hline
\end{tabular}

\footnotetext{
${ }^{24}$ Laboratório de Informática
} 


\begin{tabular}{|l|l|l|}
\hline & $\begin{array}{l}\text { Giordano, Maria J. } \\
\text { Bechara }\end{array}$ & \\
\hline $\begin{array}{l}\text { IF-06 Estratégias Didáticas para o Ensino } \\
\text { de Luz e Cor }\end{array}$ & $\begin{array}{l}\text { Gloria Queiroz, } \\
\text { Marco A. Pacheco }\end{array}$ & UERJ \\
\hline $\begin{array}{l}\text { IF-07 Modelagem Computacional no ensino } \\
\text { de Física com o Software Modellus }\end{array}$ & $\begin{array}{l}\text { Eliane Ângela Veit, } \\
\text { Ives Solano Araújo }\end{array}$ & UFRGS \\
\hline $\begin{array}{l}\text { IF-08 O computador como instrumento de } \\
\text { medida no laboratório de física no ensino } \\
\text { médio }\end{array}$ & $\begin{array}{l}\text { Reitael Haag, Eliane } \\
\text { Veit }\end{array}$ & UFRGS \\
\hline $\begin{array}{l}\text { IF-09 Recursos na Internet para Formação } \\
\text { Continuada de Professores de Física }\end{array}$ & $\begin{array}{l}\text { Deise M. Viana, } \\
\text { Renato S. Araújo }\end{array}$ & UFRJ \\
\hline $\begin{array}{l}\text { IF-10 Utilizando a tecnologia educacional } \\
\text { na análise quantitativa de movimentos }\end{array}$ & $\begin{array}{l}\text { Iria Miller Guerrini, } \\
\text { Antonio C. Castro }\end{array}$ & USP/SC \\
\hline $\begin{array}{l}\text { IF-11 Novas tecnologias no ensino de } \\
\text { acústica }\end{array}$ & $\begin{array}{l}\text { Marisa Almeida } \\
\text { Cavalcante }\end{array}$ & GoPEF- \\
\hline
\end{tabular}

Os trabalhos apresentados em forma de Painéis e Comunicações Orais relevantes para a pesquisa realizada estarão apresentados abaixo, com seus respectivos códigos (de acordo com o Livro de Programas e Resumos do XV-SNEF) e relacionados aos seus respectivos eixos, como utilizado para a classificação no trabalho.

\begin{tabular}{|c|c|}
\hline Eixos & Códigos dos trabalhos \\
\hline Softwares & 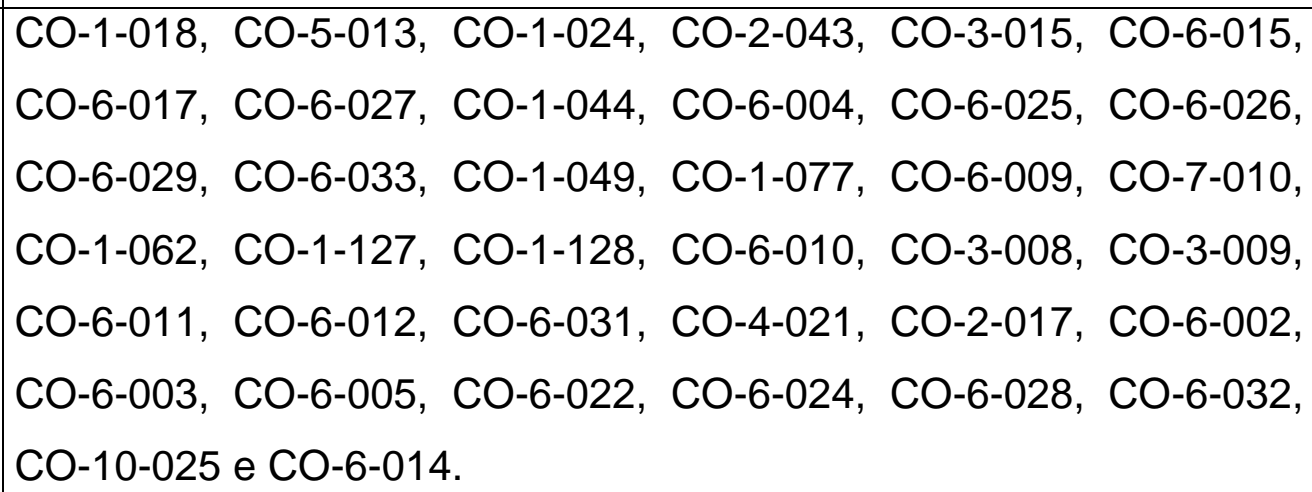 \\
\hline Internet & $\begin{array}{l}\text { CO-2-044, CO-6-006, CO-6-008, CO-6-023, CO-6-013, CO-6-022 e } \\
\text { CO-10-016. }\end{array}$ \\
\hline $\begin{array}{l}\text { Formação } \\
\text { do } \\
\text { Professor }\end{array}$ & CO-2-041, CO-2-060, CO-2-063, CO-6-001 e CO-6-016. \\
\hline
\end{tabular}


Abaixo estão apresentados os temas dos trabalhos relacionados com o uso do computador na Educação em Física que destacavam uma maior preocupação com a formação do professor.

\begin{tabular}{|c|c|c|}
\hline Tema do Trabalho apresentado & Autores & $\begin{array}{l}\text { Instituição / } \\
\text { Universidade }\end{array}$ \\
\hline $\begin{array}{l}\text { CO-2-041 - Novas Tecnologias: Os futuros } \\
\text { professores de física saberão utilizá-las? }\end{array}$ & $\begin{array}{l}\text { Araújo, Renato S. ; } \\
\text { Vianna, Deise M. }\end{array}$ & IFRJ \\
\hline $\begin{array}{l}\text { CO-2-060 - Uma abordagem Temática } \\
\text { sobre telefonia celular na formação de } \\
\text { professores de Física }\end{array}$ & $\begin{array}{l}\text { Silva, Mário J. V. } \\
\text { T.; Angotti, José A. } \\
\text { P.; Mion, Rejane A. }\end{array}$ & UFSC/UEPG \\
\hline $\begin{array}{l}\text { CO-2-063 - Utilização e compreensão das } \\
\text { novas tecnologias: um novo olhar no dia-a- } \\
\text { dia do professor de física }\end{array}$ & $\begin{array}{l}\text { Tofoli, Marcos R.; } \\
\text { Hosoume, Yassuko }\end{array}$ & IFUSP \\
\hline $\begin{array}{l}\text { CO-6-001 - A educação em Física mediada } \\
\text { pelo computador }\end{array}$ & $\begin{array}{l}\text { Brizzi, Maristel L. } \\
\text { S. }\end{array}$ & UNIJUI \\
\hline $\begin{array}{l}\text { CO-6-016 - Integrando ações de inclusão } \\
\text { digital e Tecnológica: uma digressão na } \\
\text { formaçõa inicial e continuada de } \\
\text { professores de Física no norte fluminense }\end{array}$ & $\begin{array}{l}\text { Reis, Ernesto M.; } \\
\text { Linhares, Marilia } \\
\text { P.; Rapkiewicz, } \\
\text { Clevi E. }\end{array}$ & UENF \\
\hline
\end{tabular}




\section{$\underline{\text { Revista Brasileira de Ensino de Física }}$}

Tabela com os nomes dos artigos que foram classificados em um dos eixos proposto para análise e que envolvem o uso do computador na Educação em Física.

\begin{tabular}{|c|c|c|c|}
\hline & Título do Artigo & Autores & $\begin{array}{c}\text { Número / } \\
\text { Ano }\end{array}$ \\
\hline 1 & $\begin{array}{l}\text { O Uso de Computadores no Ensino de } \\
\text { Física. Parte I: Potencialidade e Uso Real }\end{array}$ & $\begin{array}{l}\text { Paulo Ricardo da } \\
\text { Silva Rosa }\end{array}$ & $\begin{array}{l}\text { № } 2 \\
1995\end{array}$ \\
\hline 2 & Usando a Porta Paralela do Micro PC & $\begin{array}{lll}\text { Dione } & \text { Fagundes, } \\
\text { Josimar } & \text { Sartori, T. } \\
\text { Catunda e } & \text { L. A } & \text { O } \\
\text { Nunes. } & \end{array}$ & $\begin{array}{l}\text { № } \quad 2 \\
1995\end{array}$ \\
\hline 3 & $\begin{array}{l}\text { Programa Computacional para Cálculos } \\
\text { de Funções Especiais }\end{array}$ & Nilo Makiuchi & \begin{tabular}{r|r|}
$№ 4-$ \\
1995
\end{tabular} \\
\hline 4 & $\begin{array}{l}\text { Simulação gráfica em computador do } \\
\text { comportamento de uma cadeia atômica } \\
\text { linear }\end{array}$ & $\begin{array}{l}\text { Luciano T. Peixoto e } \\
\text { Keydson Q. Gomes }\end{array}$ & $\begin{array}{l}\text { № } 2 \\
1998\end{array}$ \\
\hline 5 & $\begin{array}{l}\text { Aquisição de dados e aplicação simples } \\
\text { usando a porta paralela do micro PC }\end{array}$ & $\begin{array}{lll}\text { Sousa, } & \text { P. } & \text { F.; } \\
\text { Sartori, J.; } & \text { Bell, } & \text { M. } \\
\text { J. V.; Nunes, L. } & \end{array}$ & $\begin{array}{l}\text { № } \quad 3 \\
1998\end{array}$ \\
\hline 6 & $\begin{array}{l}\text { Mecânica gráfica, um exemplo de física } \\
\text { no WWW }\end{array}$ & $\begin{array}{ll}\text { Dietrich Schiel e } \\
\text { outros }\end{array}$ & $\begin{array}{l}\text { № } \quad 4 \\
1998\end{array}$ \\
\hline 7 & $\begin{array}{l}\text { Proposta de um laboratório didático em } \\
\text { micro escala assistido por computador } \\
\text { para o estudo de Mecânica. }\end{array}$ & $\begin{array}{l}\text { Marisa Almeida } \\
\text { Cavalcante, } \\
\text { Cristiane R. C. } \\
\text { Tavolaro e outros }\end{array}$ & $\begin{array}{l}\text { № } 1 \\
1999\end{array}$ \\
\hline 8 & $\begin{array}{l}\text { Cuidados na utilização de sistemas de } \\
\text { aquisição de dados no ensino de física }\end{array}$ & $\begin{array}{l}\text { Marisa Almeida } \\
\text { Cavalcante, } \\
\text { Cristiane } \\
\text { Tavolaro }\end{array}$ & $\begin{array}{l}\text { № } \quad 2 \\
2000\end{array}$ \\
\hline 9 & $\begin{array}{llll}\text { Experimentos } & \text { didáticos } & \text { para } & \text { a } \\
\text { determinação } & \text { da } \quad \text { velocidade } & \text { de }\end{array}$ & $\begin{array}{lll}\text { Vagner } & & \text { Bernal } \\
\text { Barbeta } & \text { e } & \text { Cláudia }\end{array}$ & $\begin{array}{l}\text { № } \quad 4 \\
2000\end{array}$ \\
\hline
\end{tabular}




\begin{tabular}{|c|c|c|c|}
\hline & $\begin{array}{l}\text { propagação do som no ar, assistido por } \\
\text { computador }\end{array}$ & $\mathrm{R}$ & \\
\hline 10 & $\begin{array}{l}\text { Utilização do computador como } \\
\text { instrumento de Ensino - uma perspectiva } \\
\text { de aprendizagem significativa }\end{array}$ & 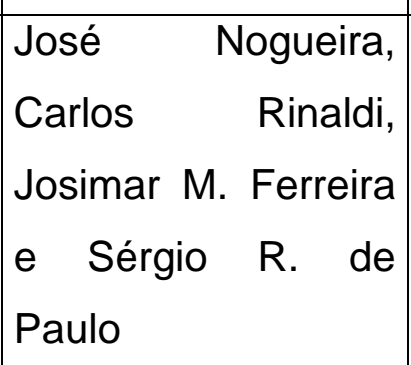 & $\begin{array}{ll}\text { № } & 4 \\
2000\end{array}$ \\
\hline 11 & $\begin{array}{l}\text { Aquisição de dados com placa de som do } \\
\text { computador }\end{array}$ & \begin{tabular}{|l|} 
Erivaldo \\
Montarroyos \\
Wictor C. Magno
\end{tabular} & $\begin{array}{ll}\text { № } & 1 \\
2001\end{array}$ \\
\hline 12 & $\begin{array}{l}\text { O uso da Internet na compreensão de } \\
\text { temas de Física Moderna para Ensino } \\
\text { Médio. }\end{array}$ & $\begin{array}{l}\text { Marisa A. } \\
\text { Cavalcante, } \\
\text { Anderson Piffer e } \\
\text { Patrícia Nakamura }\end{array}$ & $\begin{array}{ll}\text { № } & 1 \\
2001\end{array}$ \\
\hline 13 & $\begin{array}{l}\text { Utilizando a placa de som do micro PC no } \\
\text { laboratório didático de física }\end{array}$ & Rafael Haag & $\begin{array}{ll}\text { № } & 2 \\
2001\end{array}$ \\
\hline 14 & $\begin{array}{l}\text { Simulações de experiências como } \\
\text { ferramenta de demonstração virtual em } \\
\text { aulas de teoria de Física }\end{array}$ & $\begin{array}{l}\text { Issao Yamamoto e } \\
\text { Vagner } \quad \text { Bernal } \\
\text { Barbeta }\end{array}$ & $\begin{array}{lr}\text { № } & 2 \\
2001\end{array}$ \\
\hline 15 & $\begin{array}{l}\text { Aquisição de dados usando Logo e a } \\
\text { porta de jogos de um PC }\end{array}$ & $\begin{array}{l}\text { Aguiar, } \quad \text { C. } \quad \text { E.; } \\
\text { Laudares, }\end{array}$ & $\begin{array}{ll}\text { № } & 4 \\
2001\end{array}$ \\
\hline 16 & $\begin{array}{l}\text { Possibilidades e limitações das } \\
\text { simulações computacionais no ensino de } \\
\text { física }\end{array}$ & $\begin{array}{l}\text { Alexandre Medeiros } \\
\text { e Cleide Farias de } \\
\text { Medeiros }\end{array}$ & $\begin{array}{lll}№ & 2 & - \\
2002 & (77)\end{array}$ \\
\hline 17 & $\begin{array}{l}\text { Modelagem no ensino/aprendizagem de } \\
\text { física e os novos parâmetros curriculares } \\
\text { nacionais para o ensino médio }\end{array}$ & $\begin{array}{l}\text { Veit, E. A.; Teodoro, } \\
\text { V. D. }\end{array}$ & $\begin{array}{l}\text { № } 2- \\
2002 \text { (87) }\end{array}$ \\
\hline 18 & $\begin{array}{l}\text { Utilizando tecnologia computacional na } \\
\text { análise quantitativa de movimento de uma } \\
\text { atividade para alunos de ensino médio }\end{array}$ & $\begin{array}{l}\text { Mônica G. } \\
\text { Menezes, Dietrich } \\
\text { Schiel e outros }\end{array}$ & \begin{tabular}{|l|}
$№ 2-$ \\
$2002(97)$
\end{tabular} \\
\hline 19 & $\begin{array}{l}\text { Simulação Monte Carlo com repesagem } \\
\text { aplicada ao calor específico }\end{array}$ & Roberto da Silva & $\begin{array}{l}\text { № } 2- \\
2002 \\
(103)\end{array}$ \\
\hline 20 & A utilização da modelagem computacional & Guiseppe Camilleti & $\begin{array}{l}\text { № } 2- \\
2002\end{array}$ \\
\hline
\end{tabular}




\begin{tabular}{|c|c|c|c|}
\hline & $\begin{array}{l}\text { semiquantitativa do no estudo do sistema } \\
\text { mola-massa }\end{array}$ & e Laércio Ferracioli & $(110)$ \\
\hline 21 & $\begin{array}{l}\text { Análise e simulação de ondas sonoras } \\
\text { assistidas por computador }\end{array}$ & $\begin{array}{l}\text { Lucas Bleicher, } \\
\text { Moésio M. da silva e } \\
\text { outros }\end{array}$ & $\begin{array}{l}\text { № } 2- \\
2002 \\
(129)\end{array}$ \\
\hline 22 & $\begin{array}{l}\text { Estratégia para utilizar o programa } \\
\text { PROMETEUS na alteração das } \\
\text { concepções da Mecânica }\end{array}$ & $\begin{array}{l}\text { Shirley T. Gobara e } \\
\text { outros }\end{array}$ & $\begin{array}{l}\text { № } 2- \\
2002 \\
(134)\end{array}$ \\
\hline 23 & $\begin{array}{l}\text { Determinação dos coeficientes de atrito } \\
\text { estático e cinético utilizando-se a } \\
\text { aquisição automática de dados }\end{array}$ & $\begin{array}{l}\text { Vera L. F. Mossman } \\
\text { e outros }\end{array}$ & $\begin{array}{l}\text { № } 2- \\
2002 \\
(146)\end{array}$ \\
\hline 24 & O estudo de colisões através do som & $\begin{array}{l}\text { Marisa A. } \\
\text { Cavalcante e outros }\end{array}$ & $\begin{array}{l}\text { № } 2- \\
2002 \\
(150) \\
\end{array}$ \\
\hline 25 & $\begin{array}{l}\text { Desenvolvimento e utilização de um } \\
\text { programa de análise de imagens para o } \\
\text { estudo de tópicos de Mecânica clássica }\end{array}$ & $\begin{array}{l}\text { Vagner B. Barbeta e } \\
\text { Issao Yamamoto }\end{array}$ & $\begin{array}{l}\text { № } 2- \\
2002 \\
(158)\end{array}$ \\
\hline 26 & $\begin{array}{l}\text { Produção de filmes didáticos de curta } \\
\text { metragem e CD-ROMs para o ensino de } \\
\text { física }\end{array}$ & $\begin{array}{l}\text { Jurandir H. Rohling } \\
\text { e outros }\end{array}$ & $\begin{array}{l}\text { № } 2- \\
2002 \\
(168)\end{array}$ \\
\hline 27 & $\begin{array}{l}\text { llustrando a segunda Lei de Newton no } \\
\text { século } X X I\end{array}$ & Veit, E. A. e outros & $\begin{array}{l}\text { № } 2- \\
2002 \\
(176)\end{array}$ \\
\hline 28 & $\begin{array}{l}\text { Sistema de realidade virtual para } \\
\text { simulação e visualização de cargas } \\
\text { pontuais discretas e seu campo elétrico }\end{array}$ & $\begin{array}{l}\text { Antônio V. dos } \\
\text { Santos e outros }\end{array}$ & $\begin{array}{l}\text { № } 2- \\
2002 \\
(185)\end{array}$ \\
\hline 29 & $\begin{array}{l}\text { Propriedades mecânicas e geométricas } \\
\text { de objetos homogêneos delgados e } \\
\text { poligonais }\end{array}$ & $\begin{array}{l}\text { Hendrik T. Macedo } \\
\text { e Cláudio A. } \\
\text { Macedo }\end{array}$ & $\begin{array}{l}\text { № } 2- \\
2002 \\
(196)\end{array}$ \\
\hline 30 & $\begin{array}{l}\text { Aprendizagem de eletromagnetismo via } \\
\text { programação e computação simbólica }\end{array}$ & $\begin{array}{llll}\text { Alves, } & \text { D. } & \text { T.; } \\
\text { Amaral, } & \text { J. } & \text { V. } & \text { e } \\
\text { outros } & & & \end{array}$ & $\begin{array}{l}\text { № } 2- \\
2002 \\
(201)\end{array}$ \\
\hline 31 & $\begin{array}{l}\text { Visualizando os modos normais de } \\
\text { vibração com o computador }\end{array}$ & 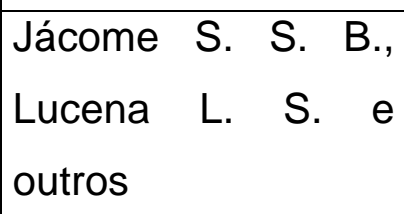 & $\begin{array}{l}\text { № } 2- \\
2002 \\
(214)\end{array}$ \\
\hline
\end{tabular}




\begin{tabular}{|l|l|l|l|}
\hline 32 & $\begin{array}{l}\text { Apresentação do software educacional } \\
\text { "Vest 21 Mecânica" }\end{array}$ & $\begin{array}{l}\text { Wilton P. Silva e } \\
\text { outros }\end{array}$ & $\begin{array}{l}\text { oo 2 - } \\
2002 \\
(221)\end{array}$ \\
\hline 33 & Laboratório Virtual de Física Nuclear & Dias, N. L. e outros & $\begin{array}{l}\text { № 2 - } \\
2002 \\
(232)\end{array}$ \\
\hline 34 & $\begin{array}{l}\text { Decodificando o controle remoto com a } \\
\text { placa de som do PC }\end{array}$ & $\begin{array}{l}\text { № 4 - } \\
\text { Erivaldo } \\
\text { Montarroyos } \\
\text { Wictor C. Magno }\end{array}$ & \\
\hline
\end{tabular}




\section{ANEXO 3.II - ANÁLISE DAS RESPOSTAS DOS PROFESSORES DE ACRE}

\section{ANEXO 3.II.1 - O COMPUTADOR}

\section{1- ÂMBITO}

1-A: GERAL

"Acho um grande progresso em tecnologia, uma máquina com uma importância para todos os ramos e que facilita nossos trabalhos e nossa vida." (B6)

"Necessário. É a forma que temos de suprir nossas necessidades, e com certeza a do aluno." (A26)

"Uma máquina necessária atualmente" (A7)

"Uma máquina de extrema importância para 90\% das tarefas que executamos. Deveria existir em todas as escolas dando suporte pedagógico ao professor." (A6)

"A utilização é infinita, não tenho a menor dúvida. No mundo globalizado em que nos encontramos é simplesmente indispensável." (A18)

"É muito importante para todos, pois é um recurso que usamos para nos atermos do que nos cerca..." (A12)

"Uma ferramenta indispensável para as atividades modernas. Digitação de textos, busca de informações, armazenamento de dados são algumas delas."

"Acho que é um aparelho de muita importância para o século que estamos vivenciando." (A14)

\section{1:B- Educação}

"Uma máquina de extrema importância para 90\% das tarefas que executamos. Deveria existir em todas as escolas dando suporte pedagógico ao professor." (A6)

"É um dos instrumentos mais importantes se bem utilizado para desenvolver as habilidades individuais de cada um." (A1) 
"Uma máquina imprescindível para o avanço da educação." (A9)

"Uma ferramenta poderosa no auxílio da prática pedagógica." (A8)

"É um equipamento indispensável no ensino-aprendizagem." (A32)

"Uma ferramenta de extrema necessidade nos dias atuais para o professor como um recurso que possibilita aproximar o aluno da realidade diante de assuntos complexos."

"Uma ferramenta de extrema importância para a educação no novo milênio" (A5)

"Uma ferramenta muito útil, se tivesse mais a mão." (A17)

\section{2- POTENCIALIDADES}

2:A- MELHORA A QUALIDADE

"É uma máquina que proporciona a quem usa uma qualidade de trabalho bem avançado." (A13)

"Um meio que torna quase tudo mais rápido e melhor, com possibilidade de comunicação e fazer trabalhos mais perfeitos." (A30)

"É uma máquina que oferece muitos artifícios para melhorar o nosso trabalho."

"Um instrumento importantíssimo nos dias de hoje para aperfeiçoar no trabalho, comunicação, lazer, ..."

" É muito útil; contribui em muito para melhorar a vida das pessoas." (A7)

"Um instrumento fantástico, que o homem utiliza para seu benefício ou não. Ele pode ser usado para complementar as aulas diárias tornando-as mais dinâmica e criativa." (A2)

"Uma ferramenta de extrema necessidade nos dias atuais para o professor como um recurso que possibilita aproximar o aluno da realidade diante de assuntos complexos."

“... temos que implantá-lo na educação que com certeza ajudará o trabalho do professor como melhorar a qualidade de ensino. Pois, melhor é para 0 aluno entender." (A10) 


\section{2:B- Aumenta a rapidez}

“...é um meio simples e rápido de consulta através do qual pode-se obter informação sobres os mais variados assunto por meio de várias fontes de pesquisa." (A21)

"É útil para agilizar alguns trabalhos."

"Instrumento de simplificação de trabalho; dispositivo de redução de tempo." (A36)

"Um meio que torna quase tudo mais rápido e melhor, com possibilidade de comunicação e fazer trabalhos mais perfeitos." (A30)

\section{2:C- Facilitador de tarefas}

"Acho um grande progresso em tecnologia, uma máquina com uma importância para todos os ramos e que facilita nossos trabalhos e nossa vida." (B6)

“..., se bem utilizado, facilita muito a realização de várias tarefas, como por exemplo elaborar uma prova." (A 35)

"O computador tem sido um grande facilitador no meu trabalho de professor."

"Importante recurso para aligeirar entendimento do processo ensinoaprendizagem."

“Ótimo, ajuda nas tarefas diárias, pesquisas, etc." (A24)

"O computador foi uma das grandes invenções da humanidade e que a vida seria muito difícil sem ele." (A8)

"É um aparelho que facilita nosso trabalho." (B3)

"O computador é um meio para ajudar o homem nas suas tarefas difíceis e até ajuda a ajustar sua vida ao cotidiano ... temos que implantá-lo na educação que com certeza ajudará o trabalho do professor como melhorar a qualidade de ensino. Pois, melhor é para o aluno entender." (A10)

"É uma máquina que facilita a elaboração dos trabalhos e ajuda também na compreensão dos alunos." (B5)

"Facilitador de tarefas" (A33) 


\section{ANEXO 3.II.2 - INTERNET}

\section{Propicia facilidade}

"O progresso, o acesso à várias informações, comodidade e pesquisas." (B6)

"Ligação com o mundo. Informações acessíveis. Facilidade." (A26)

"Um meio de comunicação e troca de informação mundial, de modo prático e rápido". (A21)

Alcance no espaço - ( $30 \%$ dos professores)

"O mundo em suas mãos." (A7)

"Ligação com o mundo. Informações acessíveis. Facilidade." (A26)

"Um meio de comunicação e troca de informação mundial, de modo prático e rápido". (A21)

"Tudo, o mundo dentro do computador." (A3)

"Comunicação com o mundo." (M2)

"O mundo a nossa frente ou a nossa mão." (A2)

"É muito bom utilizá-la pois ficamos sabendo de tudo que ocorre no mundo e ao nosso redor, temos um mundo em nossas mãos bastando apenas navegar." (A12)

"Globalização." (A18)

"É uma rede mundial de comunicação, e é muito bom para pesquisas."

"Uma rede internacional de informações, com uma facilidade que outro meio de comunicação não possui para se acessar informações com uma velocidade incrível". 
"Informações sobre o mundo, que pudessem ser recebidos e enviados."

"Estar em contato (conectado) com o mundo, sair do isolamento físico, intelectual ... estar atualizado..." (B7)

“Globalização não econômica, mas de informação." (B5) "

"O mundo em minhas mãos, didaticamente e culturalmente falando. (A9)

"É um mundo reduzido pois nela tudo se encontra." (B1)

\section{Rapidez na comunicação}

"Um meio de comunicação e troca de informação mundial, de modo prático $\underline{e}$ rápido". (A21)

"Comunicação mais rápida."

"Uma rede internacional de informações, com uma facilidade que outro meio de comunicação não possui para se acessar informações com uma velocidade incrível".

"Internet é a maneira mais rápida de se buscar informações a qualquer distância que estejamos em tempo real."

"É a maneira mais rápida de comunicar." (A28)

"Transmissão e recepção de informações com maior freqüência e rapidez." (A27)

\section{Possibilita interação}

"Uma rede de interação de conhecimento, mas que ainda não dominados por todos." (A6)

"Fonte de pesquisa, curiosidade, entretenimento, trocas de experiências, aquisição de conhecimento, trabalho." (A29)

"Um meio de comunicação e troca de informação mundial, de modo prático e rápido". (A21)

"Atualização dos conhecimentos. Tecnologia. Troca de conhecimentos." 
" Uma fonte de informação onde todos podem a qualquer momento com um computador em mãos pesquisar ou colocar informação a disposição de todos."

Fonte de pesquisa/acesso à informação/fonte de conhecimento (32\% dos professores)

"Um mundo de pesquisa e de conhecimento" (A19)

"O progresso, o acesso à várias informações, comodidade e pesquisas." (B6)

"Um dos meios mais utilizado por alunos e professores como fonte de pergunta" (A1)

"Ligação com o mundo. Informações acessíveis. Facilidade." (A26)

"Um banco de dados imenso, que diariamente fica maior, onde você pode encontrar tudo que é assunto, é só saber procurar." (A35)

"Fonte de pesquisa, curiosidade, entretenimento, trocas de experiências, aquisição de conhecimento, trabalho." (A29)

"Fonte de informação." (A34)

"É uma rede mundial de comunicação, e é muito bom para pesquisas."

"Pesquisa/informação."

"Conhecimento, pesquisa." (A14)

"Em uma rede para buscar conhecimentos e entrar em sintonia com o mundo da informação e ajuda a sair do comodismo, e atualizando ao mundo." (A10)

"Um lugar de pesquisas." (B3)

"Um mundo de informações e serviço disponível a uma grande massa populacional." ( A5)

"É um mundo reduzido pois nela tudo se encontra." (B1)

"Onde se encontra tudo" (A30)

"Que seja um meio de comunicação e informação, que pode ser intelectuais, etc .." (A25)

Apenas meio de comunicação e informação 
"Uma das melhores formas de comunicação a longa distancia". (A13)

"Informação atual."

"Uma maneira de se comunicar a distância" (A33)

"Rede eletrônica de comunicação" (A8)

"É uma rede de comunicações virtuais" (B1)

\section{Um banco de dados}

"Um banco de dados imenso, que diariamente fica maior, onde você pode encontrar tudo que é assunto, é só saber procurar." (A35)

\section{Entretenimento}

"Fonte de pesquisa, curiosidade, entretenimento, trocas de experiências, aquisição de conhecimento, trabalho." (A29)

\section{Visão negativa}

"Interessante, mas, por hora sem muita utilidade no que se refere a adquirir conhecimentos, pois, a mesma não oferece respostas com precisão." (A15)

"Uma máquina fantástica que facilita na compilação de dados, cálculos e arquivos em empresas." (A4)

"... é um instrumento que existe para facilitar a vida no sentido de pesquisas, trabalho etc." (B1)

"É um ótimo amigo na elaboração de plano de aula. Além disso é instrumento didático ligado ao mundo 24 horas." (A9)

"Melhor amigo do professor" (A31)

"Um dos elementos que deveria ser considerado como um material didático em todas as escolas" (A25)

"Um equipamento eletrônico fundamental para o aprendizado, para proporcionar nova forma de conhecimento, excelente laboratório para testes e experimentos." (A29) 


\section{2:D- Fonte de pesquisa e conhecimento}

"Uma ferramenta de maior importância para a comunicação e principalmente como forma de adquirir conhecimento." (A3)

"...é um meio simples e rápido de consulta através do qual pode-se obter informação sobres os mais variados assunto por meio de várias fontes de pesquisa." (A21)

"Que é uma fonte de informação e pesquisa." (A34)

"Excelente ferramenta de estudo, pesquisa, entretenimento, entre outros." (M2)

“...dentre muitos o melhor meio para pesquisa." (A12)

"Um bom instrumento pedagógico de pesquisa e conhecimento."

\section{3- Computador significa progresso/}

“Acho um grande progresso em tecnologia, uma máquina...". (B6)

"Um grande aliado aos conhecimentos científicos e tecnológicos." (A15)

"O computador foi uma das grandes invenções da humanidade e que a vida seria muito difícil sem ele." (A8)

"A ciência deve utilizar essas tecnologias para facilitar e até mesmo melhorar seu trabalho. Além disso deve usá-las para fazer novas descobertas." (B3)

"Sim, mas a tecnologia está desapontando na frente e não está dando lugar para a ciência, pois essas tendências tecnológicas nada têm a ver de fato com a ciência." (B10)

"Você ainda quer saber $p /$ que serve a tecnologia, que na verdade são parafernálias, que os levam ao stress mental. [...] Por favor não deixe que essa utopia da informação ou mitologia da tecnologia tome conta de você." (B10)

"Eu me vejo num sistema bárbaro e simplesmente usurpador, que vem causando problemas na maioria dos alunos que ainda não conseguiram seu ponto crítico, e são enganados por essas tecnologias que vituperam o ser humano." (B10)

"É através da Ciência que alcançamos as tecnologias novas, em função disso utilizamos as novas tecnologias para facilitar as novas descobertas da ciência." (A28) 
"O computador é uma máquina que faz várias funções ao mesmo tempo, em função disso, só veio acelerar o progresso em muitos setores de nossa sociedade." (A28)

\section{4- Não substitui o homem}

"O computador não é completo e não substitui o homem." (A6)

"É um instrumento sofisticado, mas que ainda não substitui a mente humana." (B1)

\section{5- Deslumbramento}

"Excelente." (A19)

" Maravilhoso. Excelente ferramenta de estudo, pesquisa, entretenimento, entre outros." (M2)

" Um instrumento fantástico, que o homem utiliza para seu benefício ou não. Ele pode ser usado para complementar as aulas diárias tornando-as mais dinâmica e criativa." (A2) 


\section{ANEXO 3.II.3 - COMO OS PROFESSORES SE VÊEM E PENSAM DIANTE DAS NOVAS TECNOLOGIAS}

\section{1- função positiva}

"No meu ponto de vista as tecnologias ajudam ao professor ter uma melhor qualidade de ensino." (A13)

"Os professores vêem essa tecnologias como uma nova ferramenta muito útil para facilitar seu trabalho." (A3)

"Sensacional, pois o recurso utilizado é fundamental p/ todos nós; é um meio e não um fim." (A12)

"Essas novas tecnologias, só tende a melhorar os nossos níveis de conhecimento, fazendo com que os nossas mentes e o nosso desenvolvimento crítico cresça." (A15)

"Os professores acomodados ignoram e até acham desnecessário. Aqueles profs. comprometidos com o ensino, entende que é necessário atualizar-se, acompanhar as mudanças que vem ocorrendo, pois assim, as aulas vão se tornando mais atraentes."

"Interessados em poder acessa-los, por ser um meio facilitador de informações e de trabalho."

"Com novas fontes e possibilidades de adquirir e renovar os conhecimentos."

"Que vai ter o seu trabalho facilitado." (A9)

"Os professores vêem essas tecnologias como uma aliada no processo ensino-aprendizagem." (B8)

"Muitos podem até pensar que podem ser substituídos, mas o computador é um instrumento que só veio a somar no seu trabalho." (A28)

"Facilita as explicações e a aprendizagem. É melhor." (A25)

\section{2- medo e temor}

"Alguns sentem medo, outros simplesmente admiram, mas têm outros que utilizam essa tecnologia para melhor expor seus trabalhos" (A1)

"Há muitos que tem temor! Mas, muitos estão alterando seus programas de aulas, por perceberem que é necessário avançar com a mesma velocidade da tecnologia." (A26) 
"Alguns têm medo, outros aceitam naturalmente, outros já utilizam normalmente essa tecnologia em favor da educação." (A7)

"Assustados. Pois os que não estão preparados serão vencidos pelo tempo." (A19)

"A maioria dos colegas 'estão', ou tem medo dessas mudanças na tecnologia, pois caminha a passos largos..." (A2)

"Muitos ficam assustados por não conhecer, porém depois que as conhecem ficam fascinados." (M2)

"Muitos acham necessário e importante e alguns temem a sua utilização." (A21)

"Com alegria, pois percebem que o auxílio da tecnologia contribui para o aprendizado e não temem a tecnologia como ameaça." (A29)

"Atônitos. A maioria não sabe usa-las de forma prática, aliás, não sabem usa-las de forma alguma." (A35)

"Com medo das novas tecnologias, porque não foram preparados para manusearam essas máquinas maravilhosas, ou seja, precisariam conhecelos para depois transmitirem as vantagens dessas novas tecnologias. " (A8)

\section{3- apreensivos e perdidos}

"Apreensivos, pois alguns não conseguem entender certas tecnologias. Teria que existir essa disciplina já desde cedo nas escolas." (A6)

"A grande maioria se vê perdido em um meio onde os alunos entendem melhor da máquina do que os mesmos."

"Apreensivos, pois muitos professores ainda não tiveram a oportunidade ou não interessaram em utilizar um computador."

"Se conhecem/praticam, como facilitador. Se desconhecem/abominam, com desprezo e críticas."

"Uma nova proposta de trabalho. O problema é como aplicar."

"Muitos se sentem perdidos sem saber o que fazer. Outros querem utilizar essas novas tecnologias mas não sabem como agir." (B7)

"Obsoletos e defasados." (A36)

"Perdidos, por falta de recursos e estudos para uma boa utilização dessas tecnologias." (B3) 


\section{4 - sem domínio do objeto}

"Alguns que são conhecedores pensam em uma nova visão para o ensino. Os que são menos conhecidos ainda não tem uma visão de como associar ao ensino as novas tecnologias." (B5)

"Eu acredito que tudo aquilo que vem para ajudar é bem vindo. Portanto o professor deve se sentir mais seguro, uma vez que seus alunos podem ampliar aquilo que o professor expõe." (B1)

"Os que ainda não dominam a tecnologia se sentem pressionados para dominar o mais rapidamente possível a nova tecnologia." (A4)

"Ainda não sabem bem como trabalhar." (B4)

"Se ele for um agente ativo, tranqüilo, pois, se ele estiver sempre se reciclando, acompanhando os avanços ele sempre vai se encaixar no sistema (necessidades educacionais)." (A5)

"Num mar cheio de conhecimento e será que estamos preparados para essa tecnologia? Como se preparar?" (B9)

"De mãos atadas". (A17)

"Alguns, impossibilitados de usa-lo, ou por ainda não saber, ou porque não dispõe do equipamento." (A30)

"Preocupante, pois nem todos têm recursos de estar usando essas novas tecnologias." (A31)

\section{5- Outros}

"Alguns por não terem conhecimento a ignoram, mas em uma grande maioria reconhecesse sua suma importância." (B6)

"Acredito numa nova ordem de aprendizagem, por exemplo, uma reciclagem, direcionada ao próprio micro-computador." (A18)

"A falta de incentivo econômico não permite o acesso a maioria dos professores." (A34)

"Boa opção."

"Os professores a cada dia tem que buscar mais conhecimentos, para poder acompanhar essa realidade."

"De forma privilegiada pois é uma grande inovação que estão tendo contato e transferindo para seus alunos." (A14)

"Alguns devem e procuram se adaptar, outros, em final de carreira, já se aposentando, nem ligam." (A24) 
"Otimistas, pois são induzidos a fazer parte desse avanço tecnológico." (A32)

"Apesar de todos não dominarem com perfeição seu manuseio, acho que é muito interessante para todos." (A33)

"Eu me vejo num sistema bárbaro e simplesmente usurpador, que vem causando problemas na maioria dos alunos que ainda não conseguiram seu ponto crítico, e são enganados por essas tecnologias que vituperam o ser humano." (B10) 


\section{ANEXO 3.II.4 - EDUCAÇÃO}

\section{Simplesmente auxilia}

"[O computador] ... Deveria existir em todas as escolas dando suporte pedagógico ao professor." (A6)

"Com certeza. O computador é um recurso facilitador. [ do processo de ensino]." (B6)

"[O computador] ... É a forma que temos de suprir nossas necessidades, e com certeza a do aluno." (A26)

"Sim, principalmente por ser um incentivo ao aluno." (A26)

"[O computador] ... Ele pode ser usado para complementar as aulas diárias tornando-as mais dinâmica e criativa." (A2)

"Claro, os computadores têm ajudado a facilitar o ensino em várias escolas." (A2)

"O computador tem sido um grande facilitador no meu trabalho de professor."

"Poderia ser um recurso que complemente o processo de ensino."

"[O computador] Importante recurso para aligeirar entendimento do processo ensino-aprendizagem."

"O computador é importante na elaboração de programas que podem facilitar o desenvolvimento do conhecimento."

"Como instrumento pedagógico."

"[Internet] Que o ensino está se revolucionando." (A24)

"[O computador] Uma ferramenta poderosa no auxílio da prática pedagógica." (A8)

"[O computador] Uma máquina imprescindível para o avanço da educação." (A9)

"[O computador] É um equipamento indispensável no ensino-aprendizagem." (A32)

"[O computador] É uma máquina que facilita a elaboração dos trabalhos e ajuda também na compreensão dos alunos." (B5)

"O computador... temos que implantá-lo na educação que com certeza ajudará o trabalho do professor como melhorar a qualidade de ensino. Pois, melhor é para o aluno entender." (A10) 
"Ajudando nas tarefas do professor relacionadas à função." (A33)

"[O computador] Uma ferramenta de extrema importância para a educação no novo milênio" (A5)

"O objetivo do computador é facilitar a vida do aluno." (B9)

"[O computador]Um dos elementos que deveria ser considerado como um material didático em todas as escolas" (A25)

"Para facilitar para os professores e também para os alunos." (A31)

"[O computador] Melhor amigo do professor" (A31)

\section{1- Preparo do professor}

"O computador facilita em tudo, por exemplo, elaboração de exercícios, apostilas, similares, pesquisa na internet etc. $O$ uso de alguns programas em áreas específicas, também facilita o processo de ensino; $C D$-ROM é um outro recurso muito importante. " (A3)

"Com um micro ligado à Internet, você pode acessar bibliotecas, pode conversar com professores do mundo inteiro e com isso facilitar o ensino." (A35)

".[O computador].., se bem utilizado, facilita muito a realização de várias tarefas, como por exemplo elaborar uma prova." (A 35)

"Como forma de ajuda ao professor no esclarecimento de conteúdo."

"Elaborar provas, alunos digitarem seus trabalho e se possível para ajudar como um recurso audio-visual nas aulas com o uso de datashow."

"Facilitar nas aulas expositivas, elaborar material didático. Ser usado pelos alunos na elaboração e pesquisa de trabalho."

"Produção de textos. Pesquisa (Internet). Utilização p/ atividades com programas educacionais, aplicando á realidade do aluno."

"Para pesquisa, realizações de trabalhos e aulas." (A14)

" Para pesquisa, para elaboração de projetos, desenhar, etc." (A8)

"Com um sistema em que pudéssemos criar programas para serem utilizados pelos alunos." (B3)

"Produção de material. Ilustração via internet." (B5)

"[O computador] É um ótimo amigo na elaboração de plano de aula. Além disso é instrumento didático ligado ao mundo 24 horas." (A9) 
"Pesquisa, revendo teorias, planejamento em cima de outros." (B9)

"Como fonte de pesquisa e na construção de experiências ou programas." (A30)

\section{2- Meio de pesquisa}

"[Internet] Um dos meios mais utilizado por alunos e professores como fonte de pergunta" (A1)

"Na consulta $p /$ internet, $p /$ pesquisas e novas descobertas nas áreas específicas e no crescimento sócio cultural de todos da escola e até do professor." (A12)

"Como meio de consulta tanto aos professores quanto aos alunos, como forma de tornar mais simples o aprendizado." (A21)

"Como fonte de pesquisa e em laboratórios para realização de experimentos." (A29)

"Além de propor uma disciplina 'informática na escola' para que o aluno se acostume ao manuseio para pesquisa e elaboração de trabalhos diversos." (A34)

"Para pesquisa na Internet, aulas com aplicativos didáticos e aulas com uso de um datashow." (A35)

"Com um micro ligado à Internet, você pode acessar bibliotecas, pode conversar com professores do mundo inteiro e com isso facilitar o ensino." (A35)

"Para pesquisa dos alunos. Se ligar a Internet. Interação dos alunos com a tecnologia atual."

"Facilitar nas aulas expositivas, elaborar material didático. Ser usado pelos alunos na elaboração e pesquisa de trabalho."

"Instrumento de pesquisa e educação através dos programas elaborados e por elaborar.

"Produção de textos. Pesquisa (Internet). Utilização $\mathrm{p} /$ atividades com programas educacionais, aplicando á realidade do aluno."

"Os professores poderiam usá-lo para dar suas aulas utilizando softwares, pesquisas na internet." (B7)

"Para pesquisa, realizações de trabalhos e aulas." (A14)

"Que as escolas tivessem salas bem amplas para alocar microcomputadores em redes, para pesquisas dos alunos." (A24)

"Para pesquisa, para elaboração de projetos, desenhar, etc." (A8) 
"O computador, além de ser uma forma de entretenimento possui ferramentas $p /$ ampliar conhecimentos (pesquisa), seria com essas duas que ela conseguiria "prender" o aluno na sua busca. "(A9)

"Como fonte de pesquisa através de internet. No manuseio de programas relacionados a conteúdos afins." (A32)

"Produção de material. Ilustração via internet." (B5)

"Como um recurso didático, como busca de conhecimentos e experiências." (B5)

"Cada sala de aula deverá ter microcomputadores à disposição dos alunos para as pesquisas." (B8)

"O computador é muito útil, para as aulas práticas, porque os alunos iriam realizar várias atividades, como digitar textos, fazer pesquisa através da internet." (A28) que o aluno do professor precise se inteirar de um determinado assunto e possa utilizar a internet." (A33)

"No que se diz respeito às pesquisas tanto dos professores como dos alunos." (A33)

"Em termo de fonte de pesquisa tanto para o aluno como para o educador $e$ assim fortalece ainda mais a parte intelectual de todos (professores e alunos) (B1)

"Para que os alunos pudessem utilizá-lo p/ pesquisas, desenhos e etc." (B4)

"Usando a internet para enriquecer os seus conhecimentos." (A5)

"Pesquisa, revendo teorias, planejamento em cima de outros." (B9)

"Como fonte de pesquisa e na construção de experiências ou programas." (A30)

\section{3- ensino - aprendizagem}

\section{3-1: ensino - apresentar melhor}

"Pode ser utilizado como fonte de pesquisa, como instrumento para demonstrações audiovisuais." (A1)

"Como professor de física gostaria que o micro fosse utilizado para ilustrar certas situações." (A1)

"Com certeza, pois é um meio mais atrativo e ilustrativo para esclarecer o que muitas vezes não pode ser feito com papel e caneta ou quadro negro e giz." (A21) 
"Promove o interesse do aluno por algo novo, e facilita o entendimento áudio visual." (A34)

"Para pesquisa na Internet, aulas com aplicativos didáticos e aulas com uso de um datashow." (A35)

"[O computador] Uma ferramenta de extrema necessidade nos dias atuais para o professor como um recurso que possibilita aproximar o aluno da realidade diante de assuntos complexos."

"Permitindo que o aluno ao invés fé ficar tentando imaginar o processo ocorrendo, visualiza-se através de simulações."

"Elaborar provas, alunos digitarem seus trabalho e se possível para ajudar como um recurso audio-visual nas aulas com o uso de datashow."

"Facilitar nas aulas expositivas, elaborar material didático. Ser usado pelos alunos na elaboração e pesquisa de trabalho."

"Na explicitação de procedimentos complexos e na investigação de desafios."

"O computador facilita visualização da teoria, ou seja, é possível com o computador mostrar a teoria como ocorre na prática." (A8)

"Diminuir tempo na apresentação. Mostrar de maneira clara e precisa algo que se está ensinando." (B3)

"Nas salas de aulas, porque chamava atenção do aluno e isso faria com que ele tenha um desejo de conhecer o microcomputador, e aí sim os professores poderão mudar sua metodologia de ensino." (B10)

"Sim, através do micro facilita as explicações e conseqüentemente a aprendizagem." (A25)

"[Utilizar o computador] Como material didático." (A25)

\section{3-2: aprendizagem - atividades do aluno}

"Só através da demonstração é possível interagir com alunos, mas os programas precisam se encaixar nas realidades. "(A6)

"Primeiro o aluno tem que aprender a utilizá-lo; em seguida usaríamos para construção de gráficos, fórmulas etc." (A13)

"Exemplos e resolução de questões com quit multimídia, ou via internet." (A19)

"Complementar nossas aulas e aumentar a participação dos alunos em determinados assuntos. " (M2) 
"O computador facilita em tudo, por exemplo, elaboração de exercícios, apostilas, similares, pesquisa na internet etc. $O$ uso de alguns programas em áreas específicas, também facilita o processo de ensino; $\underline{C D-r o n}$ é um outro recurso muito importante. " (A3)

"Como fonte de pesquisa e em laboratórios para realização de experimentos." (A29)

"Auxiliando, complementando o aprendizado através de informações variadas e como fonte de experimentos." (A29)

"[O computador] Um equipamento eletrônico fundamental para o aprendizado, para proporcionar nova forma de conhecimento, excelente laboratório para testes e experimentos." (A29)

"Para pesquisa na Internet, aulas com aplicativos didáticos e aulas com uso de um datashow." (A35)

" ...é possível usar aplicativos didáticos que simulam laboratórios de química, física etc. ' (A35)

"Com CD(rom) o aluno pode ler textos, resolver exercícios, mais rápido."

"Elaborar provas, alunos digitarem seus trabalho e se possível para ajudar como um recurso audio-visual nas aulas com o uso de datashow."

"Facilitar nas aulas expositivas, elaborar material didático. Ser usado pelos alunos na elaboração e pesquisa de trabalho."

"Produção de textos. Pesquisa (Internet). Utilização p/ atividades com programas educacionais, aplicando á realidade do aluno."

"Os professores poderiam usá-lo para dar suas aulas utilizando softwares, pesquisas na internet." (B7)

"O computador, além de ser uma forma de entretenimento possui ferramentas $p /$ ampliar conhecimentos (pesquisa), seria com essas duas que ela conseguiria "prender" o aluno na sua busca. " (A9)

"Como fonte de pesquisa através de internet. No manuseio de programas relacionados a conteúdos afins." (A32)

"Com programas específicos em áreas disciplinas afins." (A36)

"Se viessem programas para uso nas áreas disciplinares e não como um simples passado de conhecimentos, ou.." (B10)

"O computador é muito útil, para as aulas práticas, porque os alunos iriam realizar várias atividades, como digitar textos, fazer pesquisa através da internet." (A28) 
"Com laboratórios e programas mais específicos na área." (A17)

\section{4- objeto de aprendizagem}

".... e colocaria o aluno em contato direto com a tecnologia e seus avanços." (B6)

"De uma forma pedagógica, para facilitar o processo de interação entre alunos e tecnologia." (A7)

"[Prefere um laboratório de micro] Para ajudar o aluno a usar as novas tecnologias." (A21)

"..Não acredito que o estudante de hoje, possa entrar num mundo globalizado como o de hoje, possa ser um bom aluno sem a utilização do microcomputador." (A18)

"Sim, sem deixar que o computador se torne em vício somente pelo prazer de dizer que estamos utilizando computadores e sim pela necessidade que $o$ mundo exige."

"Para pesquisa dos alunos. Se ligar a Internet. Interação dos alunos com a tecnologia atual."

"Para que todos os alunos pudessem ter acesso e acompanhar de perto esses avanços." (A28)

"Que os alunos tivessem mais oportunidade de manuseá-lo, mais tempo de estudo do mesmo e com o mesmo, etc" (B1)

\section{5- Respostas incríveis}

"Ao professor e aluno diminui o índice de doenças pulmonares causadas pelo giz." (A27) 